Universidade de São Paulo - USP

Faculdade de Economia, Administração e Contabilidade - FEA

Departamento de Administração

Programa de Pós-Graduação em Administração

\title{
ABORDAGEM DO GLOBAL SOURCING NAS SUBSIDIÁRIAS DE \\ MULTINACIONAIS NO BRASIL
}

Carla Nomura Picchioni

Orientador: Prof. Dr. Moacir Miranda de Oliveira Junior

\section{SÃO PAULO}


Prof. Dr. João Grandino Rodas

Reitor da Universidade de São Paulo

Prof. Dr. Reinaldo Guerreiro

Diretor da Faculdade de Economia, Administração e Contabilidade

Prof. Dr. Adalberto Américo Fischmann

Chefe do Departamento de Administração

Prof. Dr. Lindolfo Galvão de Albuquerque

Coordenador do Programa de Pós-Graduação em Administração 


\section{ABORDAGEM DO GLOBAL SOURCING NAS SUBSIDIÁRIAS DE \\ MULTINACIONAIS NO BRASIL}

Dissertação apresentada ao Departamento de Administração da Faculdade de Economia, Administração e Contabilidade da Universidade de São Paulo como requisito para a obtenção do título de Mestre em Administração.

Orientador: Prof. Dr. Moacir de Miranda Oliveira Júnior

\section{SÃO PAULO}




\section{FICHA CATALOGRÁFICA}

Elaborada pela Seção de Processamento Técnico do SBD/FEA/USP

Picchioni, Carla Nomura

Abordagem do global sourcing nas subsidiárias de multinacionais no Brasil / Carla Nomura Picchioni. -- São Paulo, 2010.

$x x x p$.

Dissertação (Mestrado) - Universidade de São Paulo, 2010.

Orientador: Moacir de Miranda Oliveira Junior.

1. Empresas multinacionais 2. Cadeia de suprimentos 3. Estratégia organizacional I. Universidade de São Paulo. Faculdade de Economia, Administração e Contabilidade II. Título.

$$
\text { CDD }-658.0236
$$


Aos meus pais, pelos ensinamentos de vida.

Ao meu esposo Marcelo e meus filhos André e Pedro, Os meus tesouros, Pela vida que me dão. 


\section{AGRADECIMENTOS}

Agradeço imensamente ao meu professor orientador, prof. Dr. Moacir Miranda de Oliveira Junior, pela orientação, ensino e dedicação na pesquisa e desenvolvimento dos trabalhos ao longo do mestrado.

Agradeço ao prof. Dr. Hamilton Corrêa pela orientação, apoio e incentivo na primeira parte do meu programa de mestrado.

Agradeço aos professores Dr. Gilmar Masiero e Dr. Felipe Mendes Borini que concederam preciosas orientações e recomendações para a elaboração da dissertação no momento da qualificação.

Ao professor Dr. Felipe Mendes Borini, cuja experiência em pesquisas foi imprescindível para a materialização deste trabalho, meu especial agradecimento.

Agradeço sinceramente a liderança da Votorantim Siderurgia, aos colegas de equipe, e em especial, ao responsável pela área de Suprimentos, Egidio José Barbosa de Oliveira que, em todos os momentos do mestrado me incentivou na realização desse projeto, assim como a Patricia Barros Viotto, da área de Desenvolvimento Humano e Organizacional da VS, educadora por natureza, no aprendizado sobre as relações humanas.

Agradeço também aos professores e funcionários da FEA-USP.

Agradeço a minha família, sempre. 


\section{Resumo}

O presente estudo procura compreender os aspectos do global sourcing que agregam valor às subsidiárias no processo de aquisição de seus componentes e serviços, que tem como pano de fundo, o acesso à fontes de suprimentos de forma global.

Estratégia de global sourcing refere-se a determinar qual unidade produtiva servirá quais mercados particulares e como componentes/mercadorias/serviços serão adquiridos (DAVIDSON 1982; KOTABE, 1992; McCLINTOCK, 2002).

O objetivo principal foi entender a relação entre as principais dimensões de global sourcing que as subsidiárias de corporações multinacionais estrangeiras instalados no Brasil têm empregado e a relação das diretrizes estratégicas da matriz, de autonomia e integração, na relação com as subsidiárias. $\mathrm{O}$ estudo abordou as dimensões de propriedade e de localização. $\mathrm{Na}$ dimensão propriedade ainda pode ser subdivida em intrafirma, quando a compra tem origem de alguma unidade do sistema corporativo, da matriz ou de outras subsidiárias, ou inter-empresa, que tem como fonte de suprimento, fornecedor independente. Já a dimensão localização considera se o fornecimento é doméstico - proveniente de fornecedores nacionais, ou externas, de fornecedores estrangeiros.

Survey foi conduzido junto a 1.200 empresas com respostas de 181 subsidiárias de empresas multinacionais localizadas em território nacional de distintos segmentos de mercado, porte e origem refletindo a composição heterogênea dessas corporações no país. De um modo geral, os resultados mostraram que a autonomia das subsidiárias relaciona-se com a compra com proveniente de fornecedores externos, e que iniciativas de integração tem resultado em compras intrafirma, ou transferência de compras realizadas pela matriz.

Com isso esperamos estar contribuindo para um melhor entendimento das teorias de global sourcing e dos papéis e estratégias das subsidiárias da corporação multinacionais em países em desenvolvimento, como o Brasil. Assume-se que a utilização das estratégias de global sourcing pode contribuir para identificar e reforçar o papel das subsidiárias de corporações multinacionais instaladas no Brasil. 


\begin{abstract}
This study proposes to understand the aspects of Global Sourcing that add value to the subsidiaries in the purchase of components and services, which has as a carrier, access to sources of supply as a whole. Global Sourcing Strategy refers to the production unit will determine which particular markets and how components/goods/services it will be purchased (DAVIDSON 1982; KOTABE, 1992; McCLINTOCK, 2002). The study aimed to understand the relationship between major dimensions of Global Sourcing, property (intra firm or inter company) and location (provider independent national or foreign), that the subsidiaries of foreign multinational corporations located in Brazil have used, and the strategic guidelines of the headquarter with the Brazilian subsidiaries, in terms of autonomy and integration. The suggested model has theoretical strategies for internationalization, management of subsidiaries, Supply Chain, Global Sourcing and Global Sourcing organizational model. To prove these assumptions, a survey research was conducted by 1,200 companies with responses from 181 subsidiaries of multinational companies located in national territory of distinct market segments, size and origin reflecting the heterogeneous composition of these corporations in the country. In general, the results confirm these assumptions are made for the model approach. We could also testify the aspects related to the less structured and more focused on relationships and governance, which are the differentials that are contributing to the supply area in organization acting increasingly complex. With this, we hope to be contributing to a better understanding of the theories of Global Sourcing and the roles and strategies of the subsidiaries in Brazil.
\end{abstract}




\section{SUMÁRIO}

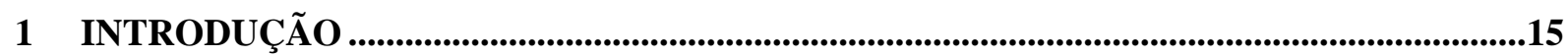

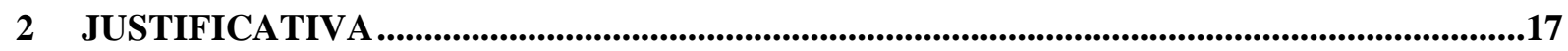

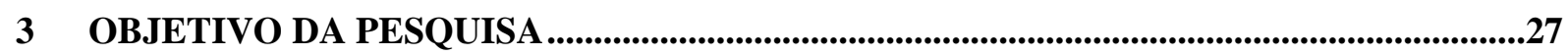

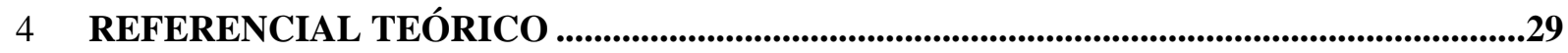

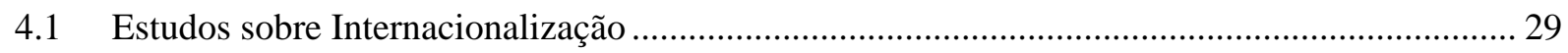

4.1.1 Internacionalização como processo de aprendizagem .......................................................... 29

4.1.2 A Internacionalização como processo de decisão racional econômico....................................... 31

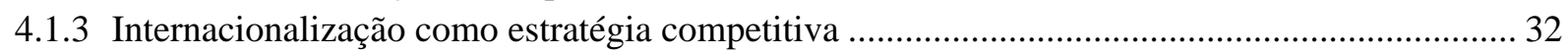

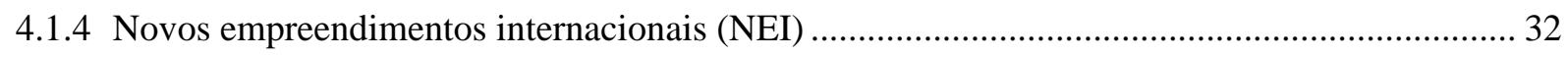

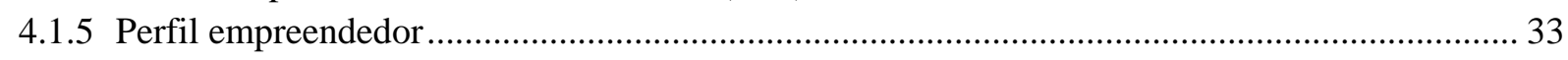

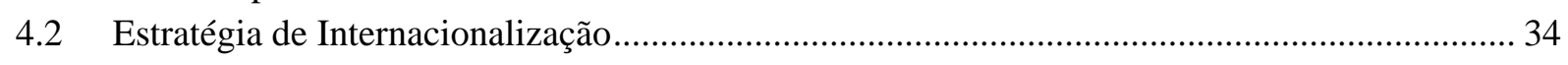

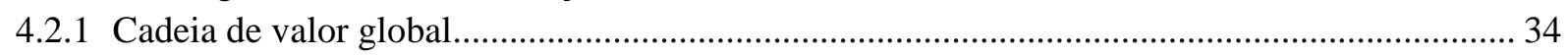

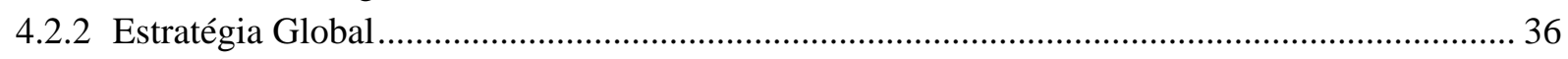

4.3 Gestão das subsidiárias de corporações multinacionais no Brasil ............................................. 38

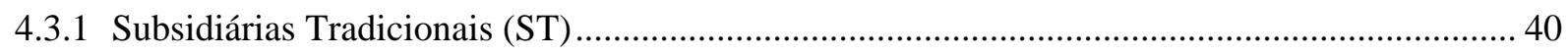

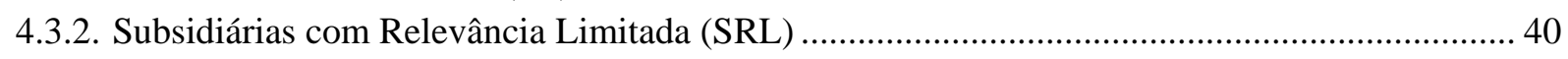

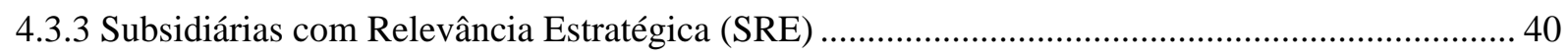

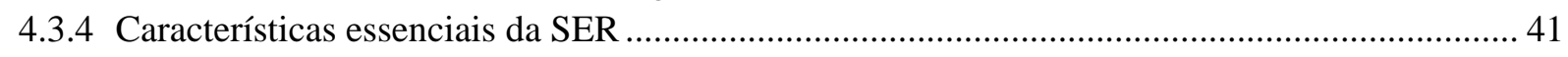

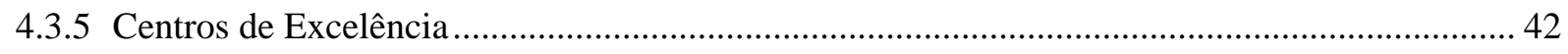

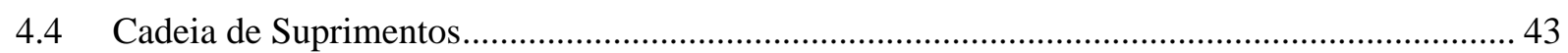

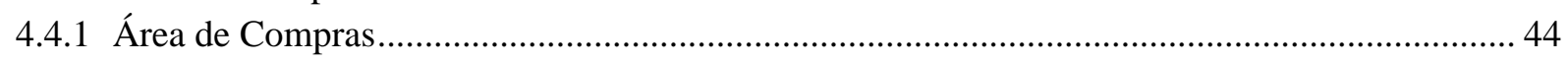

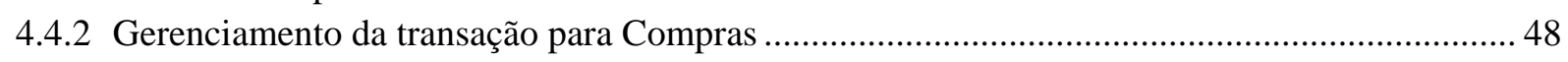

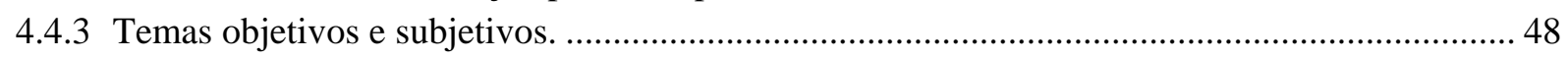

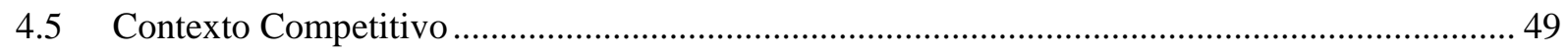

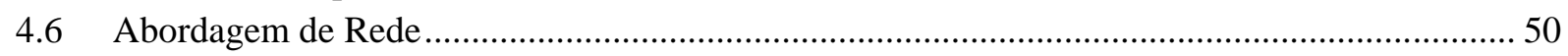

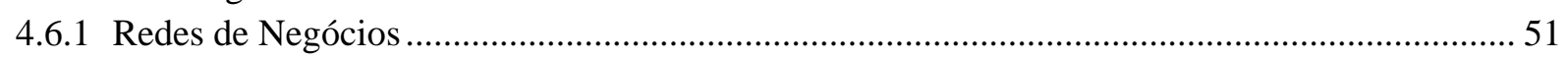

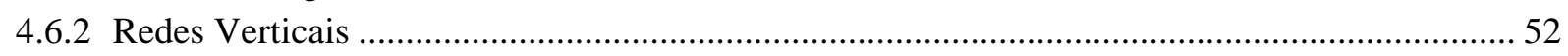

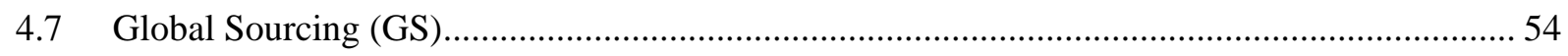

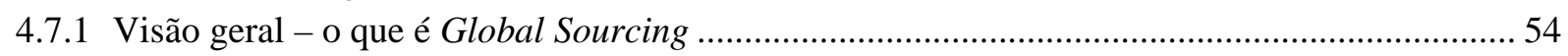

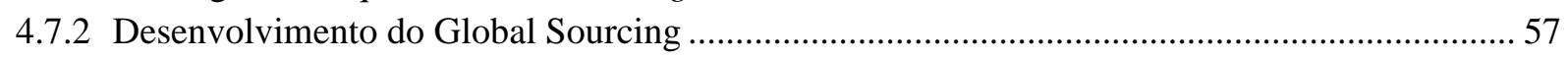

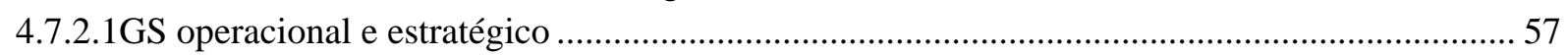

4.7.2.2Estágios de Global Sourcing ............................................................................................. 58

4.7.2.3 Características dos estágios de compras internacionais até o nível de global sourcing ............. 59

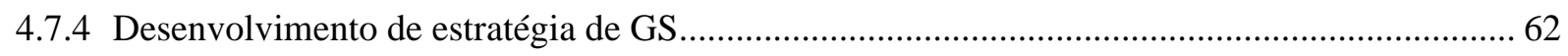

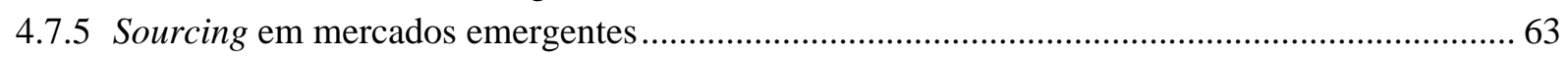

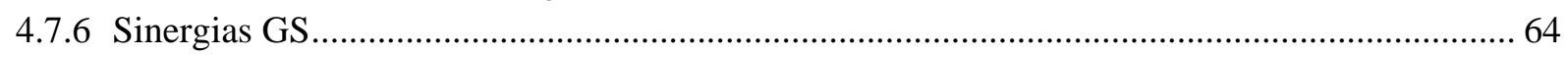

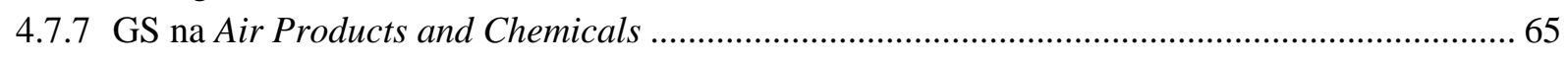

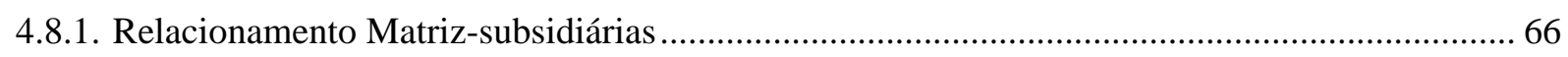

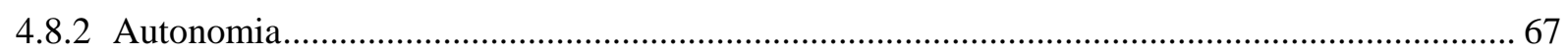

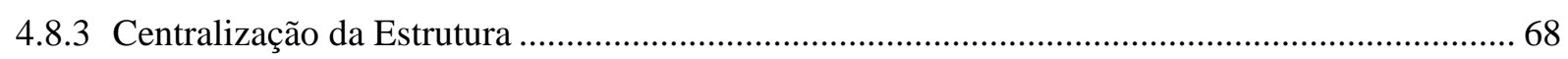




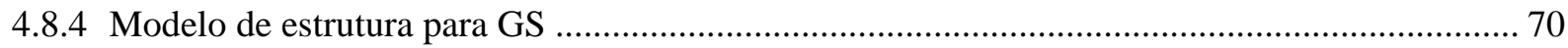

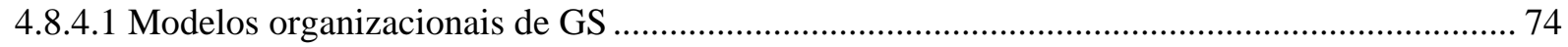

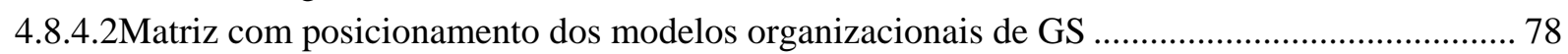

4.8.4.3 Três tipos ideais de organização de GS: modelo de compras central, modelo terceirizado e

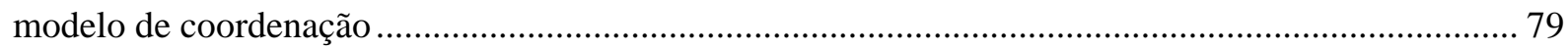

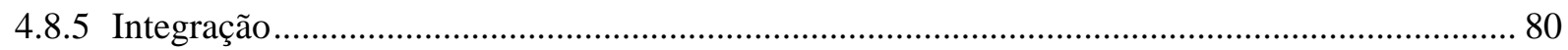

4.8.5.1Difusão do conhecimento como fator estratégico em empresas multinacionais ......................... 81

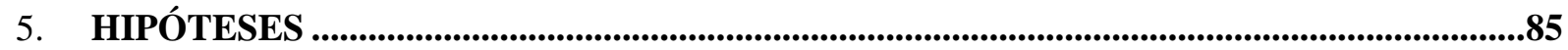

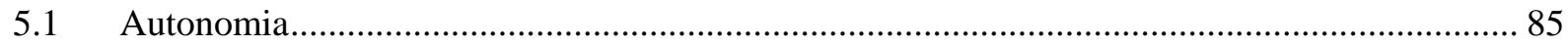

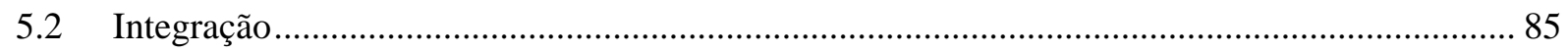

5.3 Modelo da Abordagem de Global Sourcing nas subsidiárias brasileiras de multinacionais....... 86

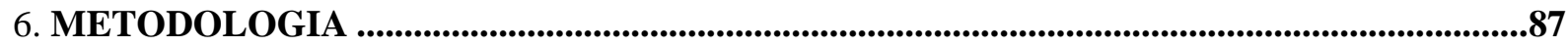

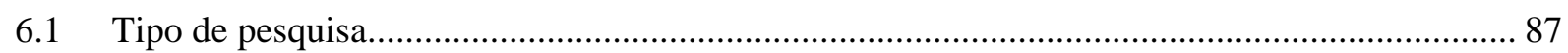

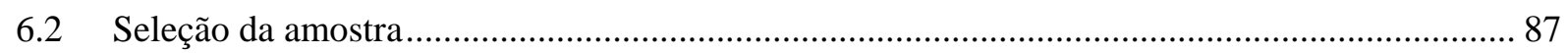

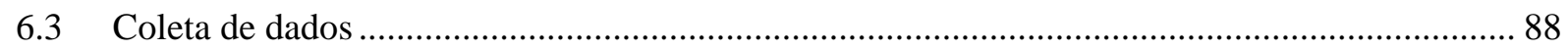

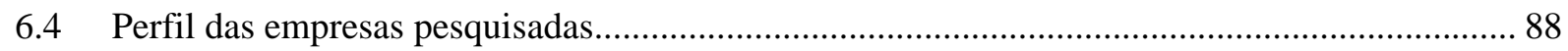

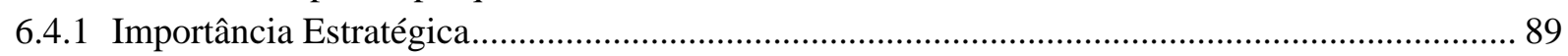

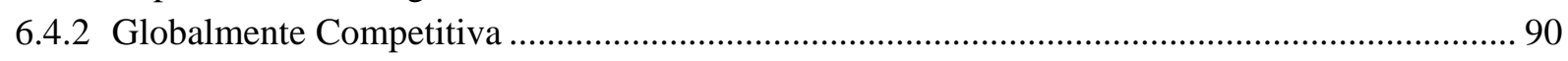

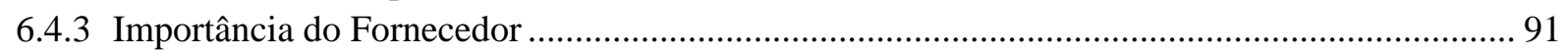

6.4.5 Regiões de comando que sua subsidiária tem relação as função de compras ............................. 91

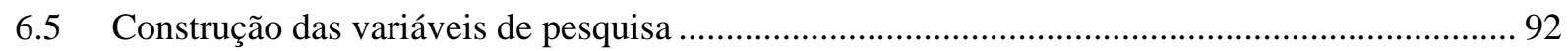

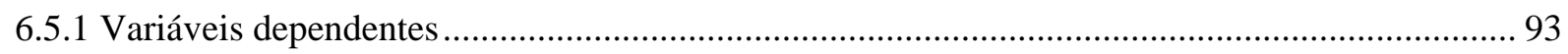

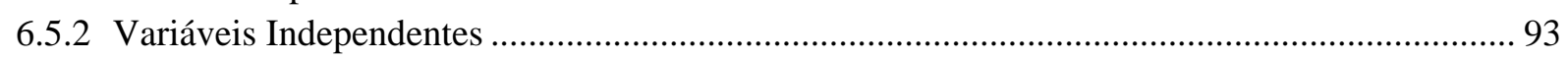

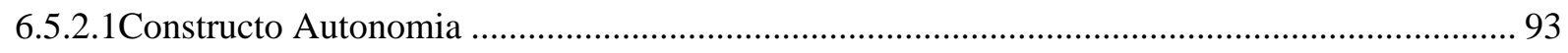

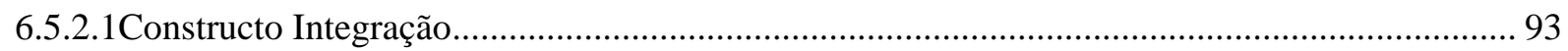

7. APRESENTAÇÃO E DISCUSSÃO DOS RESULTADOS DA PESQUISA DE CAMPO.........95

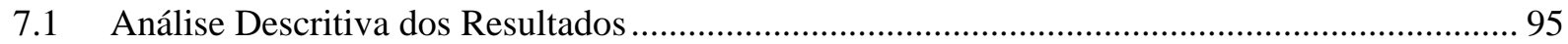

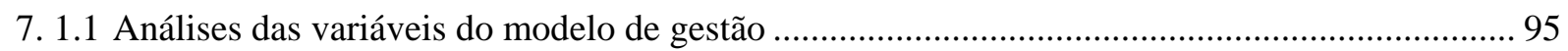

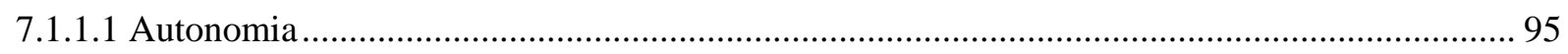

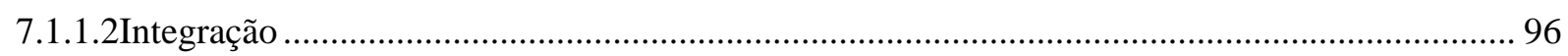

7. 1.2 Análises das variáveis da decisão estratégica de Compras ....................................................... 97

7.1.2.1 Compra dentro do sistema corporativo (intrafirma ou transferência) ou fora do sistema

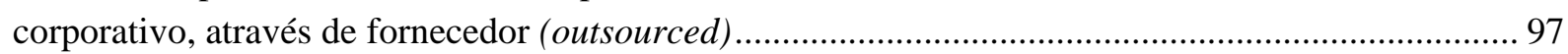

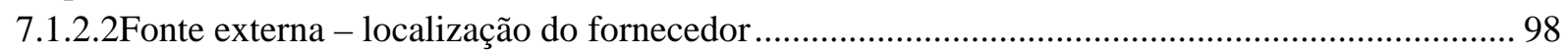

7.1.3 Quadro Resumo das Variáveis do Modelo Global Sourcing .................................................... 99

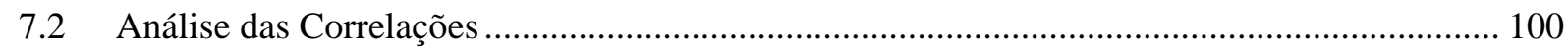

7.2.1 Análise da Correlação entre as Variáveis do Modelo de Gestão ............................................ 101

7.3 Análise de regressão múltipla ............................................................................................... 102

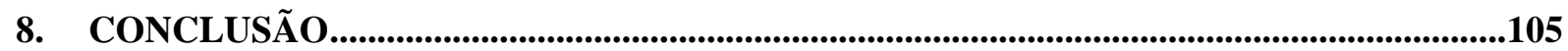

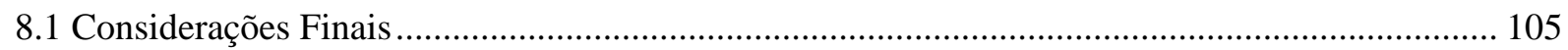

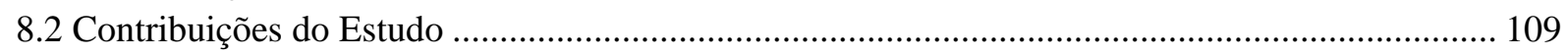


8.3 Limitações do Estudo e Sugestões para Futuras Pesquisas 109

REFERÊNCIAS 112

ANEXOS .. .125

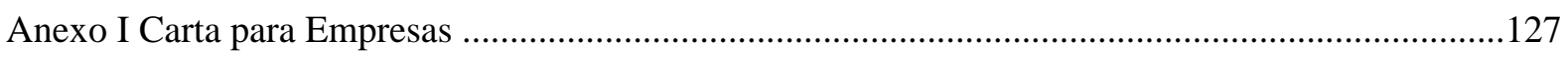

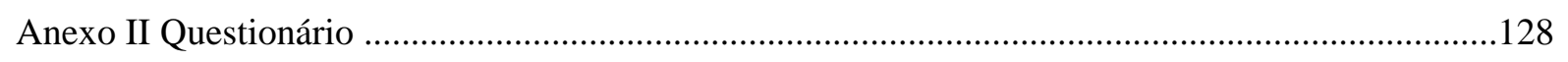

Anexo III CAPS Research - Center of Advanced Purchasing Studies..............................................129 
LISTA DE TABELAS

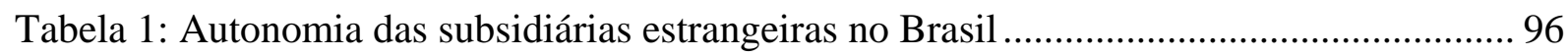

Tabela 2: Integração das subsidiárias estrangeiras no Brasil ................................................. 97

Tabela 3: Transferência - compra de fonte interna (transferência)........................................ 98

Tabela 4: Localização - compra de fornecedor nacional ou internacional ............................. 99

Tabela 5: Correlação das variáveis do modelo de gestão...................................................... 101

Tabela 6: modelo de regressão para desenvolvimento de decisão estratégica de compras.... 103 


\section{LISTA DE QUADROS}

Quadro 1- Fluxo de investimento direto em us\$ milhões

Quadro 2 - Número e \% de artigos nos 19 principais publicações de administração - 1976-1980 .18

Quadro 3 - Número e \% de artigos nos 19 principais publicações de administração - 1996-2000........19

Quadro 4 - Resumo do número e \% de artigos nos 19 principais publicações de administração............20

Quadro 5 - Relação entre o valor de compras e o valor do faturamento, ambos em dólares

americanos, de empresas consideradas referência mundial pela CAPS ..................................................22

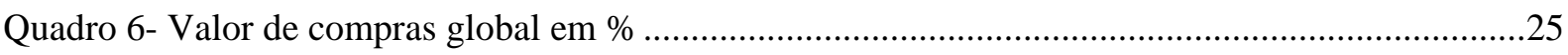

Quadro 7 - Características organizacionais de estratégias de corporações multinacionais....................39

Quadro 8 - Dimensões do global sourcing e características....................................................................62

Quadro 9- Argumentos em favor da descentralização e centralização da estrutura para global sourcing......

Quadro 10-Estratégias de multinacionais e os elementos estruturais enfatizados em cada configuração.

Quadro 11- Importância dos fornecedores para o desempenho dos negócios da subsidiária.

Quadro 12- Quadro resumo das variáveis do modelo.

Quadro 13-Resumo dos pressupostos sobre decisão estratégica de compras quadro resumo das variáveis do modelo. 


\section{LISTA DE FIGURAS}

Figura 1 - Mudanças no resultado devido a compras globais........................................... 24

Figura 2 - Tipos de estratégia em corporações multinacionais ............................................. 32

Figura 3 - Global Sourcing como programa estratégico de compras .................................... 58

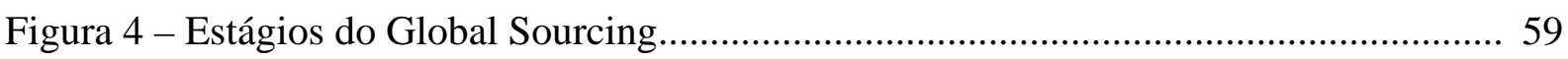

Figura 5 - Procedimento pesquisa para tipologia estrutura Global Sourcing ......................... 71

Figura 6 - Modelo analítico para organização de Global Sourcing ....................................... . 73

Figura 7 - Posicionamento do modelo organizacional de GS ............................................ 79

Figura 8 - Desenvolvimento e transferência de conhecimento.............................................. 82

Figura 9 - Esquema de estrutura de uma multinacional como uma rede diferenciada, sob a

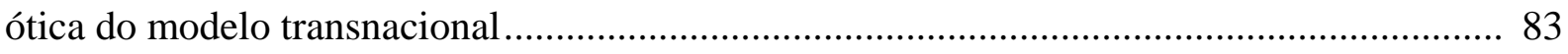

Figura 10 - Modelo da Abordagem de Global Sourcing nas subsidiárias brasileiras de

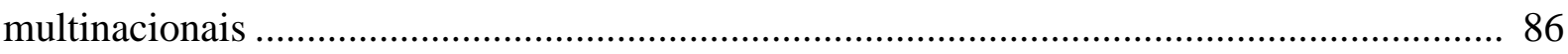

Figura 11 - Distribuição das subsidiárias de multinacionais da amostra por setor produtivo 89

Figura 12 - Importância estratégica das subsidiárias ............................................................ 90

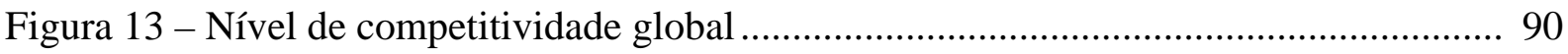

Figura 14 - Regiões de comando que a subsidiária tem relação com a função de compras.... 92 Figura 15 - Modelo de abordagem de Global Sourcing nas subsidiárias brasileiras de multinacionais 106 


\section{INTRODUÇÃO}

A crescente complexidade dos mercados internacionais, a maior integração entre as cadeias de negócios, somadas à rapidez das mudanças provocadas pelos avanços tecnológicos e maiores exigências do consumidor, são a força motriz para a globalização.

Como pano de fundo da globalização, o fluxo de comércio e ingresso de capital, representam as forças econômicas do avanço da globalização e indicadores do movimento das corporações multinacionais. Segundo dados do World Investment Report (2009), divulgados na conferência das Nações Unidas para o Comércio e Desenvolvimento (UNCTAD, na sigla em inglês), enquanto no período de 1990 a 2000, o fluxo de investimentos diretos no mundo foi da ordem de US\$ 490 bilhões, somente no ano de 2008, esse mesmo índice atingiu a cifra de US\$ 1,7 trilhões.

Esse valor foi proveniente do fluxo de investimento direto estrangeiro (IDE) mundial, gerado por 82.000 empresas multinacionais e cerca de 810.000 subsidiárias no exterior. Outro dado relevante apontado no relatório, refere-se ao fluxo de investimentos diretos no Brasil, que passou da média de US\$ 12 milhões no período de 1990 a 2000, para US\$ 45 milhões em 2008; enquanto o estoque de IDE no país, passou de US\$ 37 milhões para US\$ 287 milhões, no mesmo período de comparação. A taxa média de crescimento anual, do período de 1990 a 2008 no Brasil foi de 12,0\%, índice bem superior à média mundial de 8,9\%. Os dados demonstram que o processo de globalização é um fenômeno crescente, e que o Brasil vem despontando com forte desempenho e com potencial de grande atratividade.

\section{Quadro 1 - Fluxo de Investimento Direto em US\$ milhões}

\begin{tabular}{|l|r|r|}
\cline { 2 - 3 } \multicolumn{1}{c|}{} & $\mathbf{1 9 9 0 - 2 0 0 0}$ & $\mathbf{2 0 0 8}$ \\
\hline Brasil & 12.000 & 45.058 \\
\hline Mundo & 490.000 & 1.697 .353 \\
\hline $\begin{array}{l}\text { Participação Brasil no } \\
\text { Fluxo Mundial (\%) }\end{array}$ & $2,4 \%$ & $2,7 \%$ \\
\hline
\end{tabular}

Fonte: World Investment Report 2009. United Nations Conference on trade and development. 
A empresa multinacional possui substancial investimento direto em países estrangeiros e está engajada em uma administração ativa de suas operações internacionais (BARLETT; GHOSHAL: 1992), ela e suas subsidiárias tecem redes de relacionamentos para aquisição, produção, distribuição e venda de produtos e serviços em bases globais ao redor do mundo.

Definida como integração global de engenharia, operações, logística, compras e marketing dentro da cadeia de supply chain de uma empresa, Global Sourcing é parte integral da estratégia global (PORTER: 1990).

Estratégia de Global Sourcing (GS) também pode ser definida como, gerenciamento das interfaces entre $\mathrm{P} \& \mathrm{D}$, produção e até mesmo marketing dentro da cadeia de fornecimento (MONCZKA; TRENT: 2003a) para servir mercados particulares, tanto quanto explorar suas vantagens competitivas como integração entre matriz e subsidiárias e entre as próprias subsidiárias.

Global sourcing (GS) vai além do conceito de compras internacionais, onde o foco é tipicamente a aquisição proveniente de um determinado país para atingir preços unitários reduzidos. Ao contrário disso, o conceito inclui a integração de processo de sourcing ${ }^{1}$, operações, design, desenvolvimento e ainda pode contar com a participação de clientes internos localizados em diversos países. Isto inclui a compra combinada de necessidades de mais de uma unidade de negócios ou planta de uma empresa, além da fronteira do país aonde o bem ou serviço será utilizado. Enquanto a tradicional importação envolve uma posição mais passiva, GS requer de uma decisão pro ativa sobre quando, aonde, o que, quanto e de quem comprar (LIU; MCGOLDRICK: 1995) através de foco estratégico, a fim de realizar uma vantagem competitiva (ARNOLD: 1999).

\footnotetext{
1. Tradução livre, referente ao processo de compra, aquisição relativo à matérias-primas, insumos, materiais, equipamentos e serviços de uma empresa.
} 


\section{JUSTIFICATIVA}

A importância de temas relacionados à estratégia e gestão da internacionalização vem ganhando cada vez mais espaço na literatura acadêmica. Uma questão que se busca responder é o quanto esse tópico vem tendo destaque, e para responder a essa questão, analisamos uma pesquisa que investigou dezenove dos mais relevantes journals de Administração em dois períodos distintos. No primeiro, que compreende de 1976 a 1980, foram publicados 4802 artigos, sendo 55 artigos de Administração Internacional, representando um total de 1,1\%; 25 artigos de Pesquisa Multinacionais que representaram 0,5\% e, 30 artigos com tema além da Administração Nacional, somando num total de 110 artigos, representando assim, 2,3\%. 
Quadro 2 - Número e \% de artigos nos 19 principais publicações de Administração 1976-1980

\begin{tabular}{|c|c|c|c|c|}
\hline \multicolumn{5}{|c|}{$\begin{array}{c}\text { Table } 1 \\
\text { Number and Percentage of IM Articies in } 19 \text { Top Management } \\
\text { Journals 1976-1980 }\end{array}$} \\
\hline Journals & $\begin{array}{l}\text { Total } \\
\text { Articles } \\
1976-1980\end{array}$ & $\begin{array}{l}\text { Total IM } \\
\text { Articles } \\
\text { 1976-1980 }\end{array}$ & $\begin{array}{l}\text { MNE } \\
\text { Articles } \\
1976-1980\end{array}$ & $\begin{array}{l}\text { Cross- } \\
\text { National } \\
\text { Articles } \\
1976-1980\end{array}$ \\
\hline Academy of Management Journal & 289 & $4(1.4 \%)$ & $3(1.0 \%)$ & $1(0.3 \%)$ \\
\hline Academy of Management Review & 322 & $4(1.2 \%)$ & $4(1.2 \%)$ & $0(0.0 \%)$ \\
\hline Administrative Science Quarterly & 161 & $6(3.7 \%)$ & $1(0.6 \%)$ & $5(3.1 \%)$ \\
\hline Decision Science & 293 & $0(0.0 \%)$ & $0(0.0 \%)$ & $0(0.0 \%)$ \\
\hline Human Relations & 340 & $10(2.9 \%)$ & $4(1.2 \%)$ & $6(1.8 \%)$ \\
\hline Industrial and Labor Relations Review & 181 & $2(1.1 \%)$ & $1(0.6 \%)$ & $1(0.6 \%)$ \\
\hline Industrial Relations & 200 & $7(3.5 \%)$ & $0(0.0 \%)$ & $7(3.5 \%)$ \\
\hline Journal of Applied Behavioral Sciences & 167 & $0(0.0 \%)$ & $0(0.0 \%)$ & $0(0.0 \%)$ \\
\hline Journal of Applied Psychology & 533 & $4(0.8 \%)$ & $0(0.0 \%)$ & $4(0.8 \%)$ \\
\hline Journal of Management & 45 & $0(0.0 \%)$ & $0(0.0 \%)$ & $0(0.0 \%)$ \\
\hline Journal of Management Studies & 107 & $10(9.3 \%)$ & $6(5.6 \%)$ & $4(3.7 \%)$ \\
\hline Journal of Org and Occupational Psych. & 142 & $1(0.7 \%)$ & $0(0.0 \%)$ & $1(0.7 \%)$ \\
\hline Journal of Organizational Behavior & 21 & $0(0.0 \%)$ & $0(0.0 \%)$ & $0(0.0 \%)$ \\
\hline Journal of Vocational Behavior & 322 & $1(0.3 \%)$ & $0(0.0 \%)$ & $1(0.3 \%)$ \\
\hline Management Science & 717 & $3(0.4 \%)$ & $3(0.4 \%)$ & $0(0.0 \%)$ \\
\hline Org. Behavior and Human Dec. Processes & 274 & $0(0.0 \%)$ & $0(0.0 \%)$ & $0(0.0 \%)$ \\
\hline Personnel Psychology & 205 & $0(0.0 \%)$ & $0(0.0 \%)$ & $0(0.0 \%)$ \\
\hline Psychological Bulletin & 459 & $0(0.0 \%)$ & $0(0.0 \%)$ & $0(0.0 \%)$ \\
\hline Strategic Management Journal & 24 & $3(12.5 \%)$ & $3(12.5 \%)$ & $0(0.0 \%)$ \\
\hline Total & 4802 & $55(1.1 \%)$ & $25(0.5 \%)$ & $30(0.6 \%)$ \\
\hline
\end{tabular}

Fonte: WERNER; BROUTHERS; 2002.

Um quadro diferente é apresentado no período de 1996 a 2000: um pequeno enfraquecimento no total de artigos e um aumento significativo nas categorias de artigos internacionais, sendo os de Administração Internacional, Empresas Multinacionais, e de temas além da Gestão Nacional, respectivamente, 5,6\%, 3,1\% e 2,5\%. 
Quadro 3 - Número e \% de artigos nos 19 principais publicações de Administração - 1996-2000

\begin{tabular}{|c|c|c|c|c|}
\hline \multicolumn{5}{|c|}{$\begin{array}{c}\text { Table } 2 \\
\text { Number and Percentage of IM Articles IN } 19 \text { Top Management } \\
\text { Journals } 1996-2000\end{array}$} \\
\hline Journals & $\begin{array}{l}\text { Total } \\
\text { Articles } \\
1996-2000\end{array}$ & $\begin{array}{l}\text { Total IM } \\
\text { Articles } \\
1996-2000\end{array}$ & $\begin{array}{l}\text { MNE } \\
\text { Articles } \\
1996-2000\end{array}$ & $\begin{array}{l}\text { Cross- } \\
\text { National } \\
\text { Articles } \\
1996-2000\end{array}$ \\
\hline Academy of Management Journal & 291 & $37(12.7 \%)$ & $24(8.2 \%)$ & $13(4.5 \%)$ \\
\hline Academy of Management Review & 203 & $10(4.9 \%)$ & $6(3.0 \%)$ & $4(2.0 \%)$ \\
\hline Administrative Science Quarterly & 129 & $5(3.9 \%)$ & $2(1.6 \%)$ & $3(2.3 \%)$ \\
\hline Decision Science & 199 & $6(3.0 \%)$ & $5(2.5 \%)$ & $1(0.5 \%)$ \\
\hline Human Relations & 302 & $14(4.6 \%)$ & $4(1.3 \%)$ & $10(3.3 \%)$ \\
\hline Industrial and Labor Relations Review & 163 & $15(9.2 \%)$ & $6(3.7 \%)$ & $9(5.5 \%)$ \\
\hline Industrial Relations & 145 & $7(4.8 \%)$ & $2(1.4 \%)$ & $5(3.4 \%)$ \\
\hline Journal of Applied Behavioral Sciences & 158 & $4(2.5 \%)$ & $1(0.6 \%)$ & $3(1.9 \%)$ \\
\hline Journal of Applied Psychology & 397 & $13(3.3 \%)$ & $3(0.8 \%)$ & $10(2.5 \%)$ \\
\hline Journal of Management & 184 & $7(3.8 \%)$ & $5(2.7 \%)$ & $2(1.1 \%)$ \\
\hline Journal of Management Studies & 192 & $25(13.0 \%)$ & $19(9.9 \%)$ & $6(3.1 \%)$ \\
\hline Journal of Org and Occupational Psych. & 143 & $5(3.5 \%)$ & $0(0.0 \%)$ & $5(3.5 \%)$ \\
\hline Journal of Organizational Behavior & 270 & $12(4.4 \%)$ & $5(1.9 \%)$ & $7(2.6 \%)$ \\
\hline Journal of Vocational Behavior & 244 & $3(1.2 \%)$ & $0(0.0 \%)$ & $3(1.2 \%)$ \\
\hline Management Science & 629 & $11(1.7 \%)$ & $6(1.0 \%)$ & $5(0.8 \%)$ \\
\hline Org. Behavior and Human Dec. Processes & 342 & $6(1.8 \%)$ & $0(0.0 \%)$ & $6(1.8 \%)$ \\
\hline Personnel Psychology & 151 & $7(4.6 \%)$ & $2(1.3 \%)$ & $5(3.3 \%)$ \\
\hline Psychological Bulletin & 206 & $7(3.4 \%)$ & $0(0.0 \%)$ & $7(3.4 \%)$ \\
\hline Strategic Management Journal & 337 & $66(19.6 \%)$ & $53(15.7 \%)$ & $13(3.9 \%)$ \\
\hline Total & 4685 & $261(5.6 \%)$ & $144(3.1 \%)$ & $117(2.5 \%)$ \\
\hline
\end{tabular}

Fonte: WERNER; BROUTHERS; 2002.

Os artigos voltados para o tema de internacionalização, quando somados, tiveram sua representatividade de 2,3\% para 11,1\% em relação ao número total de artigos. A evolução do crescente interesse pelo tema pode ser observada no quadro abaixo: 
Quadro 4 - Resumo do número e \% de artigos nos 19 principais publicações de Administração

\begin{tabular}{|c|c|ccc|cr|}
\hline Período & $\begin{array}{c}\text { Total de } \\
\text { artigos }\end{array}$ & $\begin{array}{c}\text { Artigos } \\
\text { Intenational } \\
\text { Management }\end{array}$ & $\begin{array}{c}\text { Multinacional } \\
\text { enterprise } \\
\text { research }\end{array}$ & $\begin{array}{c}\text { Cross } \\
\text { National }\end{array}$ & $\begin{array}{c}\text { Total Artigos de } \\
\text { administração } \\
\text { internacional }\end{array}$ \\
\hline $\begin{array}{c}1976-1980 \\
(1)\end{array}$ & 4802 & $\begin{array}{c}55 \\
1,1 \%\end{array}$ & $\begin{array}{c}25 \\
0,5 \%\end{array}$ & $\begin{array}{c}30 \\
0,6 \%\end{array}$ & 110 & $2,3 \%$ \\
\hline $\begin{array}{c}1996-2000 \\
(2)\end{array}$ & 4685 & $\begin{array}{c}261 \\
5,6 \%\end{array}$ & $\begin{array}{c}144 \\
3,1 \%\end{array}$ & $\begin{array}{c}117 \\
2,5 \%\end{array}$ & 522 & $11,1 \%$ \\
\hline $\begin{array}{c}\% \text { do perído } \\
(2) /(1)\end{array}$ & $-2,4 \%$ & $374,5 \%$ & $476,0 \%$ & $290,0 \%$ & $374,5 \%$ & $386,4 \%$ \\
\hline
\end{tabular}

Fonte: a Autora, com base no artigo WERNER; BROUTHERS (2002).

Sob o aspecto empresarial, é notório que o processo de globalização trouxe grandes impactos na natureza das oportunidades de mercado e pressões competitivas para os produtores ao redor do mundo. Outro aspecto relevante relacionado à competição global, é como as empresas têm desenvolvido vantagens competitivas na sua estratégia de internacionalização.

Dentro da estratégia de internacionalização, um dos grandes impactos refere-se à forma como as empresas realizam suas operações, e na gestão dos seus negócios globalmente. Destacamse as mudanças de comportamento no processo das aquisições em bases globais, regionais e mesmo de produtores locais (HUBERT, 2005). No epicentro desse processo, podemos relacionar as estratégias de Global Sourcing voltadas pela forma como as empresas adquirem seus produtos e serviços.

A globalização da competição continua como um caminho sem volta (BARLETT; GHOSHAL; BIRKINSHAW: 2003; CZINKOTA; RONKAINEN: 2005). Enquanto empresas operam globalmente, tem-se redefinido sua produção e estratégia de marketing; as empresas mais ou menos falharam em fazê-lo no que diz respeito à estratégia e atividade de sourcing (KOTABE; MURRAY: 2004; TRENT; MONCZKA: 2002).

Tendo que a cadeia de suprimentos é o conjunto de materiais necessários para o funcionamento de uma empresa comercial ou fabricante, e que envolve todos os níveis de fornecimento do produto, desde a matéria-prima bruta até a entrega do produto no seu destino final (DANTAS, 2005:148), além do fluxo reverso de materiais para reciclagem, descarte e 
devoluções, em muitas das indústrias globalizadas de hoje, a área de suprimentos, que administra a cadeia de suprimentos é uma das funções estratégicas com um dos maiores impactos potencias em uma empresa, em termos de rentabilidade de longo prazo (LEENDERS et al.; 1989). Surpreendentemente, a literatura, somente recentemente, considerou a estratégia de suprimentos como um tema crítico e até o momento, uma perspectiva explícita internacional na estratégia de suprimentos continua um campo árido (KOTABE; MURRAY: 2004).

Prevalece uma tendência de que em muitas indústrias vêm aumentando o nível de empresas contratadas para fornecer materiais, componentes, sistemas, subsistemas, (MONCZKA, TRENT \& HANDFIELD: 2001), assim como os fornecedores vem desenvolvendo responsabilidades por uma porção, cada vez maior, no fornecimento de materiais usados em produtos acabados e também em gerir um grande número de processos e funções que antes eram controlados pela organização de seus clientes (HANDFIELD; NICHOLS: 2004).

A importância dessas aquisições pode ser ilustrada pela representatividade do seu valor nas corporações. Em muitas indústrias, o valor gasto na aquisição de matérias-primas, materiais e serviços, frequentemente é da ordem de $45 \%$ do faturamento de uma empresa (LEENDERS et al.1989), como demonstra pesquisa envolvendo empresas com atuação global (CAPS Research - Center of Advanced Purchasing Studies; 2009²). Em algumas indústrias essa participação é superior a 50\%, como são os casos da indústria automotiva e de transporte, a química, produtos manufaturados, engenharia/construção, bebidas e alimentos, metais e minas, entre outras. O estudo foi coordenado pelo Institute for Supply Management e W.P. Carey School of Business at Arizona State University (2009).

Abaixo, podemos conferir um quadro com as indústrias e a relação entre o valor de compras e o faturamento, onde podemos ver a relação entre o valor de compras e o valor do faturamento, ambos em dólares americanos, de empresas consideradas como referência mundial pela CAPS.

2 Conferir em ANEXOS. 
Quadro 5 - Relação entre o valor de compras e o valor do faturamento, ambos em dólares americanos, de empresas consideradas referência mundial pela CAPS

\section{Indústria}

Aeroespacial/Defesa

Automotiva e Transporte

Química

Software - programas de computadores

Produtos de consumo manufaturados

Bebidas e Alimentos

Laboratórios

Eletrônica

Engenharia / Construção

Serviços Financeiros

Serviços saúde

Manufatura industrial

Metais e minas

Petróleo

Farmacêutico

Indústria
Total Valor das Compras/Total

Faturamento (ano de 2008)
$46,11 \%$

$56,75 \%$

$52,52 \%$

$30,30 \%$

$52,67 \%$

$57,09 \%$

$41,74 \%$

$49,00 \%$

$68,28 \%$

$21,92 \%$

$42,52 \%$

$47,94 \%$

$51,35 \%$

$28,65 \%$

$48,80 \%$

Total Valor das Compras/Total

Faturamento (ano de 2008)

$\begin{array}{ll}\text { Revenda } & 18,78 \% \\ \text { Semicondutor } & 55,73 \% \\ \text { Serviços de transporte } & 50,84 \% \\ \text { Utilities } & 37,66 \%\end{array}$

Média

$45,19 \%$

Fonte: CAPS Research (Center of Advanced Purchasing Studies), Cross industry report standard benchmarks; novembro/2009

Além da representatividade do montante, sob a responsabilidade da área de suprimentos na atividade de aquisição, as tendências apontam destaque do tema, conforme pesquisa realizada pela Fundação Malcom Baldrige National Quality Award, junto a presidentes de organizações 
americanas (BOVET; MARTHA: 2000). Entre as prioridades de planejamento, apontado por 95\% dos executivos, estas se tornaram mais globais. Adicionalmente, cerca de $80 \%$ destes executivos mencionaram como prioridade, a redução de custos e melhoria no gerenciamento da cadeia de suprimentos globais (MONCZKA; TRENT: 2003b).

É importante ressaltar que Global Sourcing (GS), difere de compras internacionais em pelo menos dois aspectos: escopo e complexidade; pois envolve a integração e coordenação pro ativa para os suprimentos de itens, materiais e processos, designs, tecnologias além de fornecedores globais, equipes de engenharia, $P \& D$ e operações locais. Além disso, GS exige integração horizontal entre design de produto e grupos de desenvolvimento assim como entre atividades de planejamento de oferta e demanda. As organizações devem entender a maior extensão dos aspectos logísticos, aumento de regras e regulações, flutuação cambial, necessidades dos clientes e outras variáveis, como linguagem e diferenças culturais (MONCZKA: 2003b).

Um dado bastante relevante refere-se ao resultado de uma pesquisa exploratória realizada com 162 empresas com faturamento médio superior a US\$ 1,5 bilhões, de diversas nacionalidades e patrocinado por um consórcio de pesquisa intitulado Global Benchmarking Initiative (GBI), ligado a Michigan Statate University, no período de 1993 a 2000. A pesquisa trouxe importantes contribuições relacionadas à Global Sourcing. Uma delas é de que, $88 \%$ das companhias que implementaram com sucesso o Global Sourcing, atingiram economia de custo da ordem de 15\%, e em alguns casos de mais de 30\%, comparado com práticas e acordos de fornecimento local ou regional. Outras melhorias também são visíveis em aspectos tais como, qualidade, maior responsabilidade do fornecedor e maior contribuição tecnológica, entre outros (MONCZKA; TRENT, 2003b). Veja na figura 1 abaixo: 
Figura 1 - Mudanças no resultado devido a compras globais

\begin{tabular}{|c|c|c|}
\hline Changes due to worldwide sourcing ... & Performance category & Average changes \\
\hline $\begin{array}{l}88 \text { percent of firms report that purchase price } \\
\text { declined } \\
10 \text { percent report no change } \\
2 \text { percent report that purchase price increased }\end{array}$ & Total purchase price & $\begin{array}{l}\text { Purchase price } \\
\text { decreased } 15 \text { percent } \\
\text { on average }\end{array}$ \\
\hline $\begin{array}{l}73 \text { percent of firms report that total cost of } \\
\text { ownership declined } \\
24 \text { percent report no change } \\
3 \text { percent report that total cost of ownership } \\
\text { increased }\end{array}$ & $\begin{array}{l}\text { Total cost of } \\
\text { ownership }\end{array}$ & $\begin{array}{l}\text { Total cost of } \\
\text { ownership improved } \\
11 \text { percent on average }\end{array}$ \\
\hline $\begin{array}{l}43 \text { percent of firms report that supplier quality } \\
\text { improved } \\
54 \text { percent report no change } \\
3 \text { percent report that supplier quality } \\
\text { decreased }\end{array}$ & Supplier quality & $\begin{array}{l}\text { Supplier quality } \\
\text { improved } 6 \text { percent on } \\
\text { average }\end{array}$ \\
\hline $\begin{array}{l}23 \text { percent of firms report that delivery cycle } \\
\text { time shortened } \\
34 \text { percent report no change } \\
43 \text { percent report that delivery cycle time } \\
\text { lengthened }\end{array}$ & Delivery cycle time & $\begin{array}{l}\text { Delivery cycle time } \\
\text { lengthened } 5 \text { percent } \\
\text { on average }\end{array}$ \\
\hline $\begin{array}{l}32 \text { percent of firms report that on-time delivery } \\
\text { performance improved } \\
47 \text { percent report no change } \\
21 \text { percent report that delivery performance } \\
\text { worsened }\end{array}$ & $\begin{array}{l}\text { On-time delivery } \\
\text { performance }\end{array}$ & $\begin{array}{l}\text { On-time delivery } \\
\text { performance improved } \\
3 \text { percent on average }\end{array}$ \\
\hline 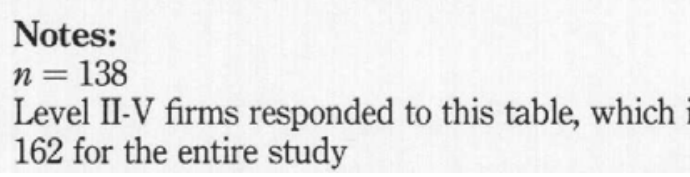 & & \\
\hline
\end{tabular}

Nota: $n=138$. Empresas de níveis II a V responderam para essa tabela, por isso a amostra é menor que o número reportado do estudo, de $n=162$.

Fonte: MONCZKA; TRENT: 2003b.

Reflexo da maior pressão competitiva, outro indicativo é que o valor de compras em base global está aumentando. Em pesquisa realizada pelos autores Monczka e Trent (2006), composta por 167 empresas americanas (66\%), européias (26\%) e o restante das empresas localizadas no Canadá, China e América do Sul, identificaram uma tendência tanto no aumento no número de empresas que vem adotando a prática de GS, assim como no valor das compras globais. Enquanto no ano 2000, o percentual de empresas com valor de compras superior a $41 \%$, era de $28 \%$, no ano de 2005 , passa a ser de $42 \%$ de empresas apontando uma estimativa de 52\% das empresas com valor de compras global superior a 41\% em 2010. 


\section{Quadro 6 - Valor de compras global em \%}

\begin{tabular}{|c|c|c|c|c|c|c|}
\hline Ano & $1-20 \%$ & $21-40 \%$ & $41-60 \%$ & $61-80 \%$ & $81-100 \%$ & \\
\hline 2000 & $54 \%$ & $17 \%$ & $10 \%$ & $8 \%$ & $10 \%$ & $28 \%$ empresas \\
\hline 2005 & $39 \%$ & $20 \%$ & $12 \%$ & $\overline{18} \overline{\%}$ & $\overline{12 \%}$ & $42 \%$ empresas \\
\hline $2010 \mathrm{e}$ & $20 \%$ & $28 \%$ & $14 \%$ & $20 \%$ & $18 \%$ & $52 \%$ empresas \\
\hline
\end{tabular}

Decrescendo

Aumentando

Fonte: MONCZKA R.M.; TRENT, R.J., 2006.

Pesquisadores sugerem que as empresas estão movendo para uma estratégia de Global Sourcing, integradas para adquirir e sustentar custos competitivos, melhoria qualidade, aumento de exposição para abrangência tecnológica mundial e aprimoramento da entrega e confiabilidade (KOTABE: 1989,1992). Outros motivos para GS incluem: (i) vantagens de incentivos governamentais, (ii) reduzir risco flutuação monetária e (iii) diversificar fonte de suprimento para minimizar risco (CAVUSGIL; YAPRAK; YEOH: 1993).

Como a tendência do GS vem se espalhando em muitas indústrias, há uma necessidade de uma coordenação efetiva da função de compras verticalmente com os objetivos da empresa, assim como horizontalmente com outras áreas da empresa para atingir eficiência na utilização dos recursos materiais (CAVUSGIL; YAPRAK; YEOH: 993). Para atenuar riscos decorrentes do relacionamento com empresas estrangeiras, ou a responsabilidade em lidar com ambientes diferentes que podem assumir riscos maiores (ZAHEER; MOSAKOWSKI: 1997).

Um dos importantes pré-requisitos apontado pelos pesquisadores, para implementar GS, é a criticidade do alinhamento da estratégia de GS com o desenho organizacional (TRENT; MONCKA: 2003; TRENT: 2004). Como essa tendência se espalha em muitas indústrias (LEE: 1996), há uma necessidade de se efetivar uma gestão que esteja voltada para entender e coordenar as relações entre as áreas/pessoas envolvidas no fluxo/processo de compras, tanto das subsidiárias quanto da matriz. Muitas são as relações existentes no fluxo de GS, tanto internas quanto externas. 
Estudos realizados por Kotabe $(1992,1998)$ têm como limitações estarem direcionados para regiões desenvolvidas, assim como a maioria dos estudos tem se concentrado em regiões desenvolvidas, apresentando uma lacuna com relação ao comportamento em países em desenvolvimento, como o Brasil.

Apesar de não ser um fenômeno recente em países desenvolvidos, os vários temas de internacionalização estão ganhando destaque no cenário nacional desde a segunda metade da década de 90 (BATISTA JR. 1998). Países em desenvolvimento, como o Brasil, considerados economicamente emergentes, se destacarão cada vez mais neste tema, devido ao potencial pouco realizado. (BARLETT; GHOSHAL: 1992).

Diante desse cenário, acreditamos que as empresas serão motivadas ainda mais a reduzir o custo de transação pela construção de uma forte rede de conhecimento compartilhada com parceiros nacionais e estrangeiros, assim como através de um processo de governança interno com os seus pares de outras subsidiárias, e na relação com a matriz.

O tema do papel das subsidiárias de corporações multinacionais no país ainda é recente e vem ganhando destaque nas produções acadêmicas, como a recente pesquisa realizada por OLIVEIRA JR.; BOEHE; BORINI (2009) e que serviu de inspiração para a elaboração deste projeto. 
De forma empírica, as questões que o estudo se propõe a responder estão relacionadas às estratégias do Global Sourcing que são aplicadas pelas subsidiárias brasileiras.

O objetivo principal é entender a relação entre as principais dimensões de Global Sourcing que as corporações multinacionais estrangeiras, instaladas no Brasil, têm empregado as diretrizes estratégicas da matriz, quanto à autonomia e integração na relação com as subsidiárias.

Serão utilizadas como referenciais duas dimensões de Global Sourcing. A primeira, de propriedade, leva em conta se a fonte de suprimento de insumos, componentes, equipamentos e serviços se dão de forma intra ou interorganizacionais; ou seja: se provém da transferência de uma outra unidade, subsidiária ou matriz, no primeiro caso ou de fornecedor independente (KOTABE: 1992; 2005).

A segunda dimensão a ser analisada, é a localização do fornecedor, que pode ser dividida em interna ou externa; ou seja: identifica a origem do fornecedor, que pode ser local, do mercado doméstico ou internacional (KOTABE: 1992; 2005).

Outra contribuição da pesquisa é buscar entender como as estratégias utilizadas podem servir como fonte de consulta e inspiração para as empresas que queiram instalar-se no país, tendo o Global Sourcing como alavanca para o sucesso.

A partir do objetivo geral, e de maneira a ampliar o alcance deste estudo, definiram-se ainda, como objetivos específicos, a pesquisa dos seguintes pontos:

- Q Qual a relação entre a integração matriz subsidiária e a compra intra-organizacional, ou seja, suprimento da subsidiária é proveniente da matriz e/ou de outras unidades da corporação?

- $\quad$ Qual a relação entre a autonomia da subsidiária e a realização das compras provenientes de fornecedores?

- Como o modelo de gestão da relação entre matriz e subsidiária (integração e autonomia) 
influencia a subsidiária na decisão de compras de fornecedor externo?

A evolução desse trabalho se dará com o alinhamento entre o papel das subsidiárias e Global Sourcing em empresas multinacionais instaladas no Brasil. 


\section{REFERENCIAL TEÓRICO}

O Capítulo 4 compreende a revisão teórica dos temas que sustentam a linha desenvolvida no estudo e tem início com uma visão geral dos estudos de internacionalização, estudos sobre internacionalização, estratégias de internacionalização, gestão das subsidiárias, cadeia de suprimentos, Global Sourcing e relação Matriz-Subsidiárias.

\subsection{Estudos sobre Internacionalização}

O processo de internacionalização, sob o aspecto acadêmico, foi estudado por diferentes autores, que segundo Fleury e Fleury (2007), pode ser classificado em três linhas predominantes: (1) internacionalização como processo de aprendizagem; (2) a internacionalização como processo de decisão racional econômico e (3) internacionalização como estratégia competitiva.

As decepções e fracassos que algumas companhias encontraram em suas operações internacionais, não ocorreram devido à análise estratégica inadequada, mas a deficiências organizacionais (BARLETT, GOSHAL: 1989). Durante cinco anos de estudo, os autores se impressionaram com o fato de que muitos administradores de companhias mundiais reconheciam o que tinham de fazer para aprimorar sua competitividade global. O desafio era como desenvolver a capacidade organizacional para fazer o que precisava ser feito organizacionalmente (BARLET, GOSHAL: 1989).

\subsubsection{Internacionalização como processo de aprendizagem}

A primeira linha de pensamento aborda os aspectos comportamentais da internacionalização, no qual a aprendizagem organizacional é o fator mais importante. $\mathrm{O}$ assunto vem sendo estudado e tem sua origem na década de 1970, quando pesquisadores da Universidade de 
Uppsala desenvolveram interesse em como as empresas manufatureiras suecas escolhiam seus mercados e formas de entrada quando decidiam se internacionalizar. A pesquisa foi influenciada pelos trabalhos sobre a firma de Cyert e March (1963) e de Penrose (2006). A Escola Nórdica de Negócios Internacionais sucedeu a Escola de Upsalla e ampliou suas linhas de pesquisa. A partir da visão daqueles pesquisadores, a firma internacional é definida como: uma organização caracterizada por processos cumulativos de aprendizagem e que apresenta uma estrutura complexa de recursos, competências e influências. Um dos trabalhos mais importantes nessa linha é a pesquisa de Johanson e Vahlne (1977), que se refere ao processo que se dá de forma incremental, por causa das incertezas e imperfeições recebidas sobre o novo mercado. Essa forma incremental se materializa por uma seqüência de investimentos graduais e incrementais.

Esse modelo sofre críticas de autores brasileiros como Rezende (2004):

$$
\begin{aligned}
& \text { “As empresas seguem trajetórias diversas em mercados } \\
& \text { estrangeiros; o modelo é ultrapassado, uma vez que foi formulado } \\
& \text { em uma época na qual o ambiente competitivo internacional era } \\
& \text { menos turbulento que hoje; e o modelo é limitado ao contexto sueco } \\
& \text { e, como resultado, explica mal o processo de internacionalização de } \\
& \text { empresas de outros países, como o Brasil”. }
\end{aligned}
$$

Além disso, a evolução da teoria de Uppsala mostra que nem sempre o processo de internacionalização segue uma linha seqüencial. É o caso das empresas emergentes, que não tem a mesma quantidade de tempo que as tradicionais tiveram para decidir qual o próximo passo a ser dada para a internacionalização. A liberalização dos mercados e a competição global diminuíram o tempo de entrada e os estágios de internacionalização (MATHEWS: 2006).

O assunto não se esgota, e novas contribuições são adicionadas como a dimensão das competências organizacionais (FLEURY, FLEURY; 2007). De acordo com Prahalad (1987), uma competência é "uma habilidade para fazer alguma coisa [...]; uma competência é construída a partir de um conjunto de "blocos” denominados recursos e ainda, a empresa 
como um portfólio de competências essenciais”.

Toda empresa tem um conjunto de recursos físico, financeiro, intangível, organizacionais e humanos. Nesta abordagem esse conjunto, ou portfólio, cria vantagens competitivas e a estratégia deve ser iniciada pelo entendimento profundo das possibilidades estratégicas desses recursos. O foco é o mercado e os competidores, sendo a vantagem competitiva derivada da exploração das oportunidades e tendências encontradas (FLEURY, 1999) e as competências da empresa no seu país de origem que podem ser internacionalizadas.

\subsubsection{A Internacionalização como processo de decisão racional econômico}

A segunda linha de pensamento sobre o tema internacionalização, tem o maior grupo de pesquisadores e define o tema como sendo "international business". Seus pioneiros foram pesquisadores na área de Economia Internacional. A primeira contribuição essencial tem como autor mais conhecido, John Dunning, que postula que as empresas se internacionalizam para explorar vantagens competitivas - vantagens específicas de propriedade, localização ou internalização.

O Paradigma Eclético, identificado pela sigla OLI foi proposto por Dunning (1993, 2000) e relaciona três conjuntos de vantagens competitivas: vantagens específicas de propriedade (Ownership), de localização (Location) e de internalização (Internalization). As vantagens específicas de propriedade estão relacionadas a ativos tangíveis, tais como recursos naturais, mão-de-obra de baixo custo e ativos intangíveis, como tecnologia, marca imagem. As vantagens específicas de localização relacionam-se à localidade onde vai ser implantada a operação internacional. Essas vantagens são denominadas estruturais quando os fatores decorrem de condições locais que vão influenciar o desempenho da subsidiária, por ex., subsídios (FLEURY, FLEURY; 2007). 


\subsubsection{Internacionalização como estratégia competitiva}

A terceira linha de pensamento (FLEURY, FLEURY; 2007), envolve a multinacional como um todo, devendo ser considerados a relação entre estratégia, estrutura e comportamento.

Os autores representativos propõem uma estratégia global total (YIP, 1992) que consiste em: desenvolver a estratégia essencial, internacionalizar essa estratégia e globalizar a estratégia internacional através da integração da estratégia entre os países (FLEURY, FLEURY, 2007). Foram criadas tipologias na busca de uma estrutura abrangente que permitisse diagnosticar a multinacional. Porter (1986) identificou três tipos baseados nos conceitos de configuração e coordenação: multidoméstica, global e internacional. Bartlett e Ghoshal (1989) propuseram quatro tipos: internacional, global, multinacional e transnacional.

Figura 2 - Tipos de estratégia em corporações multinacionais

Responsividade local Alta Alta

Baixa

\begin{tabular}{|c|c|}
\hline $\begin{array}{c}\text { Empresa } \\
\text { Multinacional }\end{array}$ & $\begin{array}{c}\text { Empresa } \\
\text { Transnacional }\end{array}$ \\
\hline Empresa & Empresa \\
Internacional & Global \\
\hline
\end{tabular}

Baixa

Alta

Integração global

FONTE: Barlett e Ghoshal (1989)

\subsubsection{Novos empreendimentos internacionais (NEI)}

O surgimento de empresas de rápida internacionalização, os novos empreendimentos internacionais (NEIs), constitui também o foco deste estudo. Segundo os autores Oviatt e McDougall (2005), a definição de NEI é um “negócio que, desde sua fundação, procura desenvolver vantagens competitivas significativas a partir do uso de recursos e das 
oportunidades de venda em múltiplos países”. Os autores ainda deram visibilidade ao tema, analisando casos de rápida internacionalização que não eram bem explicados pelas teorias tradicionais de negócios internacionais.

A tipologia proposta por Oviatt e McDougall (1991) distingue diferentes tipos de novos empreendimentos internacionais a partir do número de atividades coordenadas na cadeia de valor e do número de países envolvidos: empreendimento internacional nascido exportador/importador; comerciante multinacional, empreendimento internacional geograficamente focalizado; empreendimento nascido global. Ainda que essa proposta analise o grau de intencionalidade ou improvisação e oportunismo, a velocidade de internacionalização, as atividades internacionalizadas e o modo de operação e países envolvidos, esse modelo apresenta limitações já que focaliza apenas duas dimensões do fenômeno do empreendedorismo internacional, ou seja, o número de países envolvidos e a quantidade de atividades coordenadas na cadeia de valor.

\subsubsection{Perfil empreendedor}

Outras dimensões que a literatura vem revelando como importantes na caracterização do fenômeno de internacionalização, tais como o perfil do empreendedor, a estratégia de internacionalização, o contexto ambiental de referência, a capacidade de aprendizagem e os valores organizacionais, nem sempre são considerados da forma apropriada. (FERNANDES; JUNIOR, 2007).

A coletânea de linhas e abordagens não se limita às citadas, demonstrando o crescente interesse e importância que o tema vem apresentando. Adicionalmente, é consenso que na busca por um referencial teórico para a análise da internacionalização das empresas, assim como a literatura sobre o assunto das empresas das grandes economias emergentes que está o processo de estruturação (RAMAMURTI, 2004).

Apesar de toda a abordagem sobre a internacionalização, é importante salientar que existem várias empresas onde as questões estratégicas não se alteram se a empresa compete em um só país ou em vários. De qualquer forma, continua sendo essencial para uma empresa a perfeita 
compreensão da estrutura do seu setor e o seu posicionamento correto para que possa ganhar uma vantagem competitiva sustentável.

\subsection{Estratégia de Internacionalização}

\subsubsection{Cadeia de valor global}

Sabendo que estratégia consiste na busca deliberada de um plano de ação para desenvolver e ajustar a vantagem competitiva de uma empresa, e que este é um componente central do tema proposto, deve-se considerar as implicações da internacionalização, mesmo que na prática muitas organizações não o façam.

Deve-se considerar que como reflexo da globalização dos mercados finais e consequentemente, também dos supridores de matérias-primas ou insumos, a internacionalização tem gerado um acirramento do mercado global e uma crescente necessidade de aumento de escala de produção, fluxo de capital para novos investimentos, novas tecnologias de produção. Nesse cenário, o custo constitui uma das variáveis mais importantes na consideração da estratégia para a empresa.

O comportamento dos custos exerce uma forte influência sobre a estrutura industrial como um todo. Os custos de uma atividade de valor estão normalmente sujeitos as economias ou deseconomias de escala. Economias de escala surgem da habilidade para executar atividades de forma diferentes e mais eficientes em um volume maior (PORTER, 1992).

Assim, quando um produtor de baixo custo se internacionaliza, ele está procurando tanto um novo mercado para capturar economias de escala e fornecedores externos, quanto para ter acesso à infra-estrutura de produção para manter sua estratégia de baixo custo (INSCH, STEENSMA; 2006). A crescente competição pelas economias de escala, que levam à redução de custos e preços, é algo que contribui não somente para a competitividade do setor, como também pode refletir em toda a cadeia em que faz parte. 
Uma cadeia de valores global é a sequência de atividades necessárias para fazer um produto ou oferecer um serviço (SCHMITZ, 2005). São três as principais características:

1. As atividades são realizadas em diferentes partes do mundo;

2. Algumas atividades agregam mais valor e são mais lucrativas que outras;

3. Alguns atores na cadeia têm poder sobre outros.

Os atores poderosos são as chamadas empresas líderes e procuram liderar a cadeia. Elas definem ou forçam os termos que os demais da cadeia irão operar. A idéia central da análise da cadeia de valor é "desempacotar” as relações entre as empresas líderes e os produtores locais - as oportunidades e restrições que resultam de tais relações.

Segundo Schmitz (2005) há duas razões pelas quais as empresas compradoras globais não confiam no mercado e criam suas próprias cadeias de valor. A primeira razão refere-se à definição de produto: quanto mais as empresas perseguem a estratégia de diferenciação, por exemplo, através de design e marca maior é a necessidade de estruturar fornecedores que atendem de forma precisa as especificações do produto. A segunda razão está relacionada ao risco de falha no suprimento: o aumento da importância de fatores que não sejam somente baseados na competição por preço, tais como qualidade, tempo de resposta e confiabilidade na entrega, que junto com a crescente preocupação de confiabilidade e padrões, representa que compradores têm se tornado mais vulneráveis às falhas de desempenho dos fornecedores. Um dos muitos aspectos que a análise de cadeia de valor global nos traz, é revelar a dinâmica do sistema de produção de bens e serviços (FLEURY, FLEURY, 2006).

A cadeia de valores desagrega uma empresa nas suas atividades de relevância estratégica, para que se possa compreender o comportamento dos custos e as fontes existentes e potenciais de diferenciação (CANNICE, GEREFFI, 2006).

O conceito de cadeia de valor global (GVC - Global Value Chain) fornece uma ferramenta pragmática e útil quando nós procuramos entender questões sobre a dinâmica da geografia econômica das indústrias. A análise da GVC aponta três características principais em qualquer indústria (GEREFFI, 2008): (i) a geografia e características de relacionamento entre tarefas, ou estágios, na cadeia de valor adicionado das atividades; (ii) como o poder é distribuído e externado entre empresas e outros atores na cadeia e (iii) regra que as instituições utilizam para estruturar relações de negócios e localização da indústria. 
Para as corporações multinacionais, a integração da cadeia de valor apresenta as oportunidades e desafios (TALLMAN; YIP, 2001). Por um lado, integração da cadeia de valor permite economia de escala e escopo, exploração mais ampla da marca, e desenvolvimento de novas competências organizacionais e por outro, novas formas de competição em mercados muitas vezes, pouco conhecidos.

Um outro conceito, de Global Supply Chain Management, pode ser visto como um direcionador primário de clientes e valor acionista (SRIVASTAVA et al, 1999). A cadeia de fornecimento global consiste de múltiplos parceiros de negócios ao redor de um amplo número de países. Como um compromisso para um estoque de recursos finito (exemplo: recursos humanos, tempo) é necessário gerenciar relações da cadeia de suprimento. Decisões estratégicas que objetivem maximizar o resultado, não podem ser feitas baseadas somente numa simples relação e excluindo os demais. Nesse contexto o gestor deve ter entendimento das necessidades únicas de cada relacionamento e o gerenciamento efetivo das múltiplas relações simultaneamente (GRIFFITH; MYER, 2005).

\subsubsection{Estratégia Global}

Empresas que competem internacionalmente enfrentam dois imperativos: pressão por integração global e responsividade local (PRAHALAD; DOZ, 1987; PORTER, 1985).

A estratégia competitiva, de acordo com Porter (1985), é à busca de posição competitiva favorável em uma indústria, arena fundamental onde ocorre a concorrência, visando estabelecer uma posição lucrativa e sustentável contra as forças que determinam à concorrência. Essa determinação empresarial leva à possibilidade de expansão, de diversificação ou até mesmo de sobrevivência de uma empresa, especialmente se a sua ação envolve mercados competitivos. As competências distintivas permitem a criação e a manutenção de vantagem competitiva.

Quando relacionamos o tema indústria global enfrentando competição global, o conceito mais 
adequado é a teoria da cadeia de valor. Porter introduziu o conceito como uma ferramenta básica para analisar as fontes de vantagem competitiva através da análise das atividades de valor adicionado de uma empresa numa base global. A base do conceito é, integrar os processos logísticos e comerciais ao longo de toda a cadeia de abastecimento, buscando sinergia em que o todo é mais benéfico do que a simples soma das partes (ANSOFF, 1990). Induz-se a empresa a adquirir novas tecnologias, investir em métodos, processos e estabelecer alianças.

Outra abordagem relacionada à estratégia como determinação de marcos/metas em longo prazo e objetivos de uma empresa, é a adoção de cursos de ação e a alocação de recursos necessários para atingir tais propósitos (CHANDLER, 1990:13).

Podemos notar que no processo econômico atual funções significativas, relativas às cadeias de suprimentos, podem revelar diferenciações ou reduções de custos dos produtos, que efetivam a vantagem competitiva. A estratégia de Global Sourcing é um exemplo nesse contexto.

Sabemos que na competição internacional, grandes empresas de múltiplos produtos estão fazendo apostas em aonde adquirir e em quais mercados se dirigirem. O desafio delas para a formulação da estratégia global. É diferenciar entre os vários tipos de economias, especificarem quais fatores capturam vantagens para a firma, e determinar aonde a cadeia de valor seria quebrado para adicionar valor.

O aumento dos níveis de competição global, o atendimento às altas expectativas dos clientes e condições econômicas diversas, constitui o cenário que os administradores enfrentam atualmente. Uma tendência crescente é a terceirização de sua produção, sistemas, componentes dos subsistemas em muitas indústrias (MONCZKA; TRENT; HANDFIELD, 2001). Fornecedores sendo responsáveis por uma parcela maior de material usada na produção, e gerindo uma quantidade maior de processos, e funções que antes eram controladas pelas organizações de seus clientes (HANDFIELD; NICHOLS, 2004). Como resultado, organizações têm reconhecido que o desempenho do fornecedor é cada vez mais crítico para a própria habilidade de competir com o sucesso. Organizações americanas também perceberam que para uma competição “world class”, há exigência de uma base de fornecedores global. Outro aspecto importante encontra-se no fator humano, no 
estabelecimento de relacionamento positivo com fornecedores, e numa base de fornecimento global de alto desempenho, apresentando vantagens pela maior ênfase no relacionamento cooperativa comprador-fornecedor (HANDFIELD; NICHOLS, 2004).

\subsection{Gestão das subsidiárias de corporações multinacionais no Brasil}

As subsidiárias de modelo global e multidoméstico apesar de apresentarem menor relevância estratégica para a corporação e suscetíveis às disputas provenientes da competição interna (BIRKINSHAW; HOOD, 1998), tem sua importância estratégica, quanto a: (i) aplicação da tecnologia e das competências maduras, recriando e estendendo o ciclo de vida dos produtos e dos lucros corporativos; (ii) proporcionam ganhos de escala provenientes das produções em série e aqueles oriundos de países onde as condições são mais vantajosas e (iii) atendem necessidades específicas de um mercado, explorando o volume de vendas em potencial.

As principais características organizacionais de estratégias de corporações multinacionais estão resumidas no quadro abaixo: 


\section{Quadro 7 - Características organizacionais de estratégias de corporações multinacionais:}

\begin{tabular}{|c|c|c|c|}
\hline $\begin{array}{l}\text { Estratégias de } \\
\text { corporações } \\
\text { multinacionais }\end{array}$ & $\begin{array}{c}\text { Configuração de ativos } \\
\text { e recursos }\end{array}$ & $\begin{array}{c}\text { Papel das subsidiárias } \\
\text { no exterior }\end{array}$ & $\begin{array}{c}\text { Desenvolvimento e } \\
\text { difusão do } \\
\text { conhecimento }\end{array}$ \\
\hline Multidoméstica & $\begin{array}{l}\text { Descentralizada e auto- } \\
\text { suficiente nacionalmente }\end{array}$ & $\begin{array}{l}\text { Sentir e explorar as } \\
\text { oportunidades locais }\end{array}$ & $\begin{array}{c}\text { Conhecimento } \\
\text { desenvolvido e mantido } \\
\text { em cada unidade }\end{array}$ \\
\hline Global & $\begin{array}{c}\text { Centralizada em escala } \\
\text { global }\end{array}$ & $\begin{array}{c}\text { Implementar as } \\
\text { estratégias da matriz }\end{array}$ & $\begin{array}{c}\text { Conhecimento } \\
\text { desenvolvido e mantido } \\
\text { no centro }\end{array}$ \\
\hline Internacional & $\begin{array}{l}\text { Fontes de competências } \\
\text { básicas centralizadas, } \\
\text { outras descentralizadas. }\end{array}$ & $\begin{array}{c}\text { Adaptar e alavancar } \\
\text { competências da matriz }\end{array}$ & $\begin{array}{c}\text { Conhecimento } \\
\text { desenvolvido no centro e } \\
\text { transferido para as } \\
\text { unidades no exterior }\end{array}$ \\
\hline Transnacional & $\begin{array}{c}\text { Dispersa, } \\
\text { interdependente e } \\
\text { especializada }\end{array}$ & $\begin{array}{c}\text { Contribuições } \\
\text { diferenciadas das } \\
\text { unidades nacionais e } \\
\text { operações mundiais } \\
\text { integradas }\end{array}$ & $\begin{array}{c}\text { Conhecimento } \\
\text { desenvolvido em } \\
\text { conjunto e } \\
\text { compartilhado entre } \\
\text { diversas unidades }\end{array}$ \\
\hline
\end{tabular}

FONTE: Barlett e Ghoshal (1998).

Um modelo de empresa que atua internacionalmente classificada como transnacional, de acordo com a pesquisa de Bartlett \& Ghoshal (1992), entre outras competências, é aquela capaz de integrar os melhores processos globalmente, que consegue desenvolver, explorar e transferir o conhecimento em termos mundiais e que vê as inovações como resultado de um processo que engloba vários membros da companhia.

Importante contribuição na identificação e conceituação do papel das subsidiárias de corporações multinacionais no Brasil foi amplamente analisada em pesquisa dos autores Oliveira, Jr. et al, (2009). Os autores classificaram as subsidiárias em três tipos: 
1. Subsidiárias tradicional (ST) - podem ser implementadora e criadora local

2. Subsidiárias com relevância limitada (SRL) - podem ser plataformas globais e criadoras específicas

3. Subsidiárias com relevância estratégica (SRE)

\subsubsection{Subsidiárias Tradicionais (ST)}

Subsidiárias tradicionais (ST) em economias emergentes foram subdivididas em implementadora e criadoras locais. As primeiras são aquelas levadas a controlar seus recursos sem nenhum acesso a informações criticas. É uma subsidiária que praticamente não cria nem transfere nenhuma forma de inovação. Atua como uma grande receptora de conhecimento (GUPTA; GOVINDARAJAN, 1991). Elas são mais dependentes da matriz corporativa ou de uma subsidiária global (D’CRUZ, 1986).

\subsubsection{Subsidiárias com Relevância Limitada (SRL)}

As plataformas globais, do grupo das subsidiárias com relevância limitada (SRL) seriam as subsidiárias globalmente racionalizadas, que embora apresentem responsabilidade internacional, ainda dependem da tomada de decisão (ROTH; MORRISON, 1992). Segundo a tipologia proposta no trabalho, dentro do grupo de SRL, incluem ainda as subsidiárias criadoras específicas, casos típicos de subsidiárias que realizam inovações para o mercado local, e depois o produto final pode ser utilizado por outras subsidiárias. É um típico processo de local para global, mas com algumas limitações. Uma delas é a transferência da inovação somente como um produto final.

\subsubsection{Subsidiárias com Relevância Estratégica (SRE)}

As subsidiárias com relevância estratégica (SRE) possuem elevado grau de competências 
estratégicas e atuam em mercados importantes estrategicamente falando (BARLETT; GOSHAL, 1992). Além disso, podem ter responsabilidade global ou regional para uma linha de produtos, área de negócios ou todos os negócios de determinada área geográfica. São subsidiárias inovadoras e, ainda responsáveis pelo gerenciamento de suas próprias atividades, independentemente da matriz (BIRKINSHAW; MORRISON, 1995).

O fator preponderante que eleva a subsidiária com relevância estratégica (SRE), está centrado no processo de inovação. As SRE criam valor agregado para a corporação, criando inovações que possam ser transferidas e utilizadas por outras unidades corporativas. Elas exercem competitividade global e tem suas competências reconhecidas pela corporação como um todo.

\subsubsection{Características essenciais da SER}

Apresentaremos a partir de agora, as principais características da Subsidiária de Relevância Estratégica segundo Roth e Morrison (1992).

As atividades principais da cadeia de valor estão localizadas em vários locais geográficos. Um exemplo disso é que atividades como as de manufatura, coordenadas por uma SRE não precisam necessariamente encontrar-se no país desta subsidiária; atividades primárias, quando dispersas pelo mundo e comandadas pela subsidiária, levam a SRE ao desenvolvimento de capacidade de gerenciamento internacional, essencial para sua função. O aumento da necessidade de habilidades para gerenciar a integração das atividades pela exigência de flexibilidade estratégica para coordenar e combinar atividades primárias dispersa entre as subsidiárias, é um conjunto de concentração das atividades de suporte da cadeia de valor.

A SRE não é auto-suficiente em conhecimento, e permite à subsidiária trocar conhecimento e adquirir as melhores práticas das outras empresas da multinacional (GUPTA; GOVINDARAJAN, 1991). Elas podem desenvolver iniciativas integradas que garantem uma maior importância estratégica. 


\subsubsection{Centros de Excelência}

A subsidiária pode exercer o papel de centro de excelência pela capacidade que tem de criar e transferir competências úteis para diversas outras unidades da empresa multinacional (HOLM; PEDERSEN, 2000).

O foco dos centros de excelência são atividades primárias e as de suporte da cadeia de valor, e não a subsidiária como um todo. Por exemplo, uma SRE pode ser um centro de excelência em $\mathrm{P} \& \mathrm{D}$, marketing, produção, desenvolvimento de tecnologia de informação (TI) ou gestão da cadeia de suprimentos (supply chain) (OLIVEIRA, et al, 2009).

O conceito apresenta quatro características: (i) tem uma presença física, está localizado em alguma subsidiária. É uma área da corporação e não uma equipe de projeto ou de negócios (BIRKINSHAW, 2001); (ii) contribui com recursos tangíveis (equipamentos, licenças e patentes) como com intangíveis (conhecimentos e habilidades); (iii) tem capacidade de influenciar as outras unidades da multinacional e matriz, pela criação de competências superiores e diferenciais em um ato contínuo de transferi-las para as demais unidades da corporação; e (iv) existência de reconhecimento declarado do centro de excelência por parte das demais unidades que a utilizam.

De acordo com Birkinshaw (et al, 1998), a literatura apresenta três perspectivas que tentam explicar por que as subsidiárias podem desempenhar diferentes papéis: (i) a primeira é o determinismo ambiental. A empresa multinacional opera em diferentes ambientes e, conforme as características do ambiente local (BARTLETT; GHOSHAL, 1992). Quanto mais elevado o dinamismo da competição local, dos compradores e fornecedores, maior a probabilidade de a subsidiária desempenhar um papel de importância estratégica (PORTER, 1990); (ii) a definição do papel da subsidiária é de responsabilidade da matriz. Determinações estratégicas da matriz, quanto à estrutura, controle, comunicação e autonomia, definem a importância da subsidiária (BARLETT; GHOSHAL, 1992), e (iii) o papel é determinado por ela própria. Em relação à matriz corporativa, a subsidiária tem mais capacidade de entender a complexidade e oportunidades do local de atuação. 


\subsection{Cadeia de Suprimentos}

Arnold (1999) aponta que empresas têm desenvolvido um perfil de unidade de negócios de serviços, lidando em última análise somente com atividades de comprar e vender apresenta como conseqüência, uma vantagem competitiva que pode ser primordialmente percebida pelo reforço e destaque de atividades do gerenciamento da cadeia de suprimentos e pelo desenvolvimento de novas formas de acordo com mercados fornecedores.

Durante a década de 1980, houve uma grande quantidade de pesquisas focadas em vários aspectos de compras internacionais. O crescimento no interesse desse tópico era relacionado diretamente ao declínio da competitividade de muitas empresas americanas. E acreditava-se que o tema de compras internacionais, ajudaria a reverter esse quadro (CARR; PEARSON, 2002). Nesse período, a grande maioria das pesquisas no tema ressaltava os benefícios que as empresas americanas deveriam esperar para obter fontes offshore já que elas competiam contra empresas estrangeiras agressivas e bem preparadas (RAJAGOPAL; BERNARD 1993).

A maioria dos pesquisadores concluiu que, o benefício primário da compra internacional era a redução de custo unitário, ainda que não necessariamente a redução de custo total (MONCZKA; TRENT, 2003b). Houve pouco debate sobre a aplicabilidade da compra internacional e da compra global até o final dos anos 80, pois havia poucas empresas ocidentais que adotaram a prática do Global Sourcing.

Contudo, existiam visões contraditórias, relacionadas ao custo total e os benefícios das compras internacionais. Uma visão que se manteve, foi a do avanço tecnológico e organizacional que reduziria os custos e aumentaria a velocidade de transportes e da comunicação, portanto, facilitando a compra internacional. Por outro lado, uma diferente vertente apontada por Monczka e Trent (2003b), é a de que a distância continuaria como forte barreira para condução de negócios e que os custos reais da compra internacional são geralmente subestimados ou desconhecidos.

Outro benefício da compra internacional, citada na literatura, inclui um maior acesso a produtos e processos tecnológicos, maior qualidade, e habilidade de introduzir competição para os fornecedores da base doméstica (MONCZKA; TRENT, 2005). 
Além disso, um distinto parecer está relacionado a isso: o gerenciamento de risco. O risco poderia aumentar devido ao estoque adicional necessário, ao maior prazo de entrega pela maior distância, confiança na nova e desconhecida fonte de suprimento, sem contar a gestão de diferentes moedas, línguas e práticas de negócios.

Com isso, um novo cenário foi surgindo a partir da competição, em nível mundial, com excesso de oferta de produtos, demanda reprimida e os avanços das tecnologias de informação e comunicação que fizeram com que a gestão da cadeia de suprimentos se voltasse para o aumento da qualidade do produto e redução de custos e preços, acompanhados pela sua maior e melhor disponibilidade ao consumidor.

Handfield (1994) defende que a cadeia de suprimentos é a integração de todas as atividades associadas com o fluxo e transformação de bens, desde as matérias primas até o consumidor final, passando pelos sistemas de informações. A combinação dessas atividades se dá por meio do desenvolvimento de relações para adquirir vantagens competitivas. Dessa forma, é importante combinar vantagens competitivas com outras empresas na busca de alianças estratégicas e de redes interempresas. Investimentos em sistemas de comunicação, sistemas operacionais de computadores e acesso em alta velocidade à Internet, podem facilitar a integração interempresas, mesmo em nível mundial.

Nesse raciocínio, a celebração de alianças com outras empresas permite, por exemplo, a aquisição de produtos ou processos tecnológicos, a repartição dos custos, e a diluição dos riscos, em especial de pesquisas e desenvolvimento além do acesso a novos canais e mercados de distribuição.

\subsection{1 Área de Compras}

Nos últimos 25 anos muitas áreas vêm sofrendo mudanças, em especial, as áreas de compras com mudanças significativas dentro das empresas, de uma simples atividade de compra de bens e serviços, para além de um conjunto integrado de funções gerenciais. Tais compras têm evoluído em todos os aspectos da administração, de gerenciamento da categoria para 
gerenciamento da cadeia de suprimentos, contratos e pagamentos, e estratégia.

Como as empresas buscam além de uma visão de curto prazo e o escopo da área vem se ampliando, profissionais de compras estão prestando mais atenção não só no que eles gastam em bens e serviços, mas no custo ampliado da operação, manutenção e reposição dos itens e recursos que eles compram ao longo do tempo, numa visão ampliada da cadeia de valores.

Apesar do aumento da importância, ainda é necessário à área de compras, atingirem o reconhecimento que merece. Em uma análise crítica, isso pode ser ilustrado pelo relacionamento com diversas áreas dentro da empresa. Há duas razões para isso. A primeira é a freqüente dificuldade de registrar a contribuição específica de compras: a redução de custos é resultado da habilidade negocial com vendedores ou uma questão fortuita de mudança do mercado? Os benefícios financeiros pela escolha de um acordo de compras favorável, geralmente estende além do preço de compra inicial para outros aspectos de desempenho (como por exemplo, melhoria do capital de giro ou redução do custo financeiro), assim há mais de um aspecto a se considerar no resultado final. Em segundo lugar, a linha entre a responsabilidade de compras e aqueles de outras partes relacionadas pode ser ambígua. $\mathrm{O}$ resultado: compras geralmente dividem qualquer sucesso que atinge outros grupos; no caso de falha, contudo, a forma típica é a de levar toda a culpa (BUTTER, 2008).

A necessidade de se colocar compras em um contexto mais estratégico tem se tornado mais imediato, na atual era de crescente globalização. Global Sourcing se relaciona às decisões de compras às decisões estratégicas. Decisões estas de fazer ou comprar (make ou buy) - por exemplo - mudam a produção para uma de suas próprias subsidiárias ou terceirizá-la para produtores externos e subcontratados - são tipicamente feitas em um nível de executivos sênior. Contudo, outras decisões importantes (tais como onde comprar, de quem e sob quais condições) são comumente tratadas pelos profissionais de compras. A realidade é que, estas decisões não são mais baseadas inteiramente no entendimento do custo direto de compras ou no custo facilmente observável de transação, como gastos no transporte e taxas de importação, mas também nos outros tipos de custo de transação incluindo aqueles relacionados às diferenças culturais, institucionais e políticas.

Transações comerciais, pela sua natureza, envolvem custos de transação. Uma condição 
necessária para mudar isso é o fato que um pode se comprometer ex ante para ser capaz e desejar assumir obrigações contratuais ex post. Nem compradores nem vendedores entrarão num relacionamento de troca, a menos que eles estejam seguros que a outra parte irá cumprir plenamente as obrigações contratuais. O problema sugere os autores, pode se resolvido de formas variadas. A troca pode ser definida institucionalmente (por exemplo, num contrato legal), mas também pode ser definido pela confiança e por fornecer incentivos para comportamento de confiança.

De forma prática, o custo de transação consiste em todos os custos incorridos na aquisição de bens e serviços, tanto pela troca de direito de propriedade em um mercado transacional ou pela troca de responsabilidades: todo o desembolso e tempo gasto para coordenar a compra de bens e serviços (BUTTER; LINSE, 2008).

Os custos de transação são identificados entre custos hard e soft. Os custos hard são relativamente fáceis de quantificar - estão relacionados ao item, tais como taxas de transporte, importação e tarifas. Custos soft por sua vez, são menos acessíveis e menos claramente definidos. Ele inclui os custos de criar e verificar contratos, custos de informação, todos os custos resultante de diferenças culturais e falhas na comunicação, conhecimento ou procedimentos legais, custos incorridos na construção de confiança e reputação, construção de relacionamento, custos associados a riscos (incluindo regulação) e exigências de segurança.

Como distância entre os parceiros comerciais cresce e o sistema econômico, cultural, político e social converge num mercado globalizado, os custos "soft" tornam-se mais importantes e a área de compras torna-se mais importante estrategicamente. Além disso, a habilidade de comprar bens e serviços no menor preço possível é frequentemente menos crítico que desenvolver formas efetivas de construir pontes entre diferenças culturais e sobrepor barreiras comerciais informais. Contudo, custo de transação não pode ser reduzido pelo departamento de compras sozinho. Por causa do amplo leque de custos e seus efeitos, exige-se decisão estratégica do topo da administração.

Ao lidar com empresas estrangeiras, gerentes novos experimentam com freqüência um número de barreiras para implementação. Os custos adicionais, não associados às compras domésticas que vão desde analisar cotações de fontes estrangeiras, taxas exportação, custos 
despachante, custo de rejeição, perdas em trânsito, custos de armazenagem e estoque, suporte técnico, custo de viagem de funcionários entre outros (HANDFIELD, 1994).

A tendência em andamento de globalização tem trazido movimento crescente para especialização e fragmentação da produção como manifestado pelo crescimento em outsourcing, global sourcing e investimento estrangeiro direto (BUTTER; LINSE, 2008). Taxas de crescimento dramático em países com menor custo de produção (incluindo Índia e China) têm dado um senso de urgência dentro das companhias que operam internacionalmente e sobre como elas podem continuar a criar valor através do comércio. Dentro desse cenário, uma opção é mudar de uma produção cativa, para uma posição de liderança em orquestrar produção - desenvolvendo expertises relacionadas à produção, montagem e venda. Isso exige mudanças na forma como as empresas lidarão com os custos de transação e como as relações internacionais de comércio são estabelecidas. Assim, alterando sua atuação, as companhias podem adquirir conhecimento crítico sobre como o custo de transação pode ser reduzido.

Segundo Butter (et al, 2008), isso acontece de duas formas. O custo de transação menor possibilitará mais fragmentação da produção e outsourcing de tarefas específicas, porque eles fazem à terceirização ser rentável. Ao mesmo tempo, reforçam o conhecimento dos custos de terceirizar (em particular, conhecendo quando uma terceirização não é lucrativa devido aos inesperados e altos custos de transação soft).

Desta forma, o conhecimento do custo de transação é uma parte crítica da decisão de comércio e investimento, permitindo que a empresa reduza seus custos totais e, portanto contribuindo para que as transações atuais sejam mais rentáveis e abrindo a possibilidade para maiores volumes e negócios a serem comercializados. Manter os custos de transação baixos é algo que os autores chamam de gerenciamento da transação. Se por um lado construir confiança e desenvolver reputação requer investimento, o qual direciona para um maior custo de transação, por outro lado, uma vez que fornecedores e clientes têm estabelecido uma relação de confiança, eles podem antecipar menores custos de transação. 


\subsubsection{Gerenciamento da transação para Compras}

Segundo Butter (et al, 2008), profissionais da área de compras tem um grande desafio que é administrar a complexa interface entre a empresa e os diversos stakeholders para maximizar valor. Na atual transparência da economia global os gestores de compras devem não somente identificar e gerenciar os custos de transação. Eles devem fazê-lo em áreas onde eles têm variado grau de controle e influência. Para apoiar os gestores/administradores em entender o custo de transação quanto à exposição de custo, este será visto em duas dimensões: (1) em termos de temas objetivos e subjetivos, e (2) em termos de influência interna ou externa.

\subsubsection{Temas objetivos e subjetivos.}

Os objetivos estão amarrados com os fatores mensuráveis e são de natureza técnica ou profissional. São geralmente vinculados a custos diretos, melhoria de qualidade, tempo de entrega, custo de transporte e implicações financeiras maiores. Podem ser divididos em fatores internos e externos, como abordaremos a seguir.

\section{Fatores Internos e externos}

Por fatores internos, fator relacionado a negócios específicos entende: sua posição de mercado, a reputação e a marca. Eles são distintos dos fatores externos que estão vinculados ao desenvolvimento fora da empresa em áreas como regulação, custos de mão de obra e questões cambiais.

A combinação de fatores objetivos, subjetivos, internos e externos cria um espectro complexo de exposições que podem afetar a saúde da empresa, se não sua própria existência. Numa economia global, conhecer os riscos e oportunidades de diferentes exposições é uma competência gerencial crítica.

O custo de transação, segundo os autores Butter (et al, 2008) pode ser agrupado em três categorias, que estão alinhadas com o potencial de transação de troca: custo associado com 
contato, com contrato e com controle.

Contato: na fase de contato, o comprador procura informação sobre o produto em questão (preço e qualidade), potenciais fornecedores, ou, se o produto não existe, qual produtor será capaz de desenvolver e/ou produzi-lo. O vendedor desenvolve esforço de marketing na procura por um comprador. Neste estágio, o custo de contato é principalmente de busca e informação. Contudo, são custos perdidos (sunk costs) ocorrendo mesmo se um relacionamento comercial (compra) não é estabelecido.

Contrato: a fase de contrato é iniciada imediatamente após as partes terem se identificado e um trabalho tenha começado no sentido de se realizar o acordo. Os custos nesta fase se relacionam as negociações do termo do contrato. As partes têm que decidir como dividir as ganhos esperados do contrato e conseguir proteger seus interesses.

Controle: Envolve o monitoramento e acompanhamento do contrato. Ambos envolvem alto custo de transação, especialmente quando grandes distâncias separam os parceiros comerciais e fornecedores de cada um. Agora que a distância psicológica tem se tornado menos importante, através da redução de custo de transporte e comunicação mais rápida, distâncias culturais e institucionais podem ser maiores. Parceiros de negócios precisam monitorar os termos do acordo para verificar se a outra parte está fazendo o que foi prometido que faria. A reposta mais comum é começar um procedimento legal. Especialmente em relações internacionais de comércio, pois ações legais levam tempo e dinheiro. Ademais, estrangeiros geralmente tem dificuldades em cortes nacionais quando eles acionam uma empresa local.

\subsection{Contexto Competitivo}

De acordo com Kogut (1991), o que possibilita que uma nação desenvolva mais e, que a empresa seja líder em tecnologia e capacidades organizacionais, está alicerçada em condições específicas do país, particularmente condições apropriadas para o desenvolvimento tecnológico. 
Dunning (1988) reforça que as características locais são um grande atrativo para o crescimento dos investimentos estrangeiros ocorridos na última década do século XX.

A vantagem locacional constitui como um fator atrativo para a decisão de investimentos no exterior. Ela pode acontecer não só pela transferência de vantagens competitivas da matriz para as subsidiárias, mas sim, cada vez mais pela busca de vantagens competitivas nas subsidiárias estrangeiras. Resultado disso é o crescimento do investimento direto estrangeiro e das aquisições, com o objetivo de adquirir conhecimentos, habilidades gerenciais e competências organizacionais espalhadas pelo mundo (DUNNING, 1988).

Uma teoria aplicada a essa questão, chamada de diamante da vantagem nacional (PORTER, 1990), nos apresenta que determinados países reúnem atributos que, isolados e de forma sistemática, permitem a construção da vantagem nacional sustentada. São quatro as arestas, ou atributos, baseado em Porter: condições dos fatores; condições da demanda; setores correlatos e de apoio; e estratégia, estrutura e rivalidade das empresas.

Analisando o atributo de setores correlatos e de apoio no país, temos fornecedores melhores qualificados e inseridos numa competição internacional, fornecendo insumos com menores custos, maior rapidez e de forma preferencial. A proximidade entre fornecedores e usuários finais permite uma comunicação mais eficaz, maior roca de informações e um constante intercâmbio de idéias e inovações.

Quanto mais as empresas dos setores correlatos e de apoio forem competidores globais, maiores serão os benefícios auferidos pelas empresas da base doméstica. Fornecedores globais têm acesso às bases nacionais onde são mais competitivos e podem proporcionar as inovações do exterior que deverão ser implementadas nas empresas do país. Acredita-se que fornecedores não globais apresentem uma forte competitividade nacional.

\subsection{Abordagem de Rede}




\subsubsection{Redes de Negócios}

A internacionalização é um fenômeno que não se restringe ao modo de entrada, mas envolve o próprio processo de evolução das subsidiárias (BIRKINSHAW; HOOD, 1998), no qual os relacionamentos estabelecidos pelas subsidiárias são graduais, mas a seqüência dos modos de entrada é descontinua (REZENDE, 2002). Trata-se do processo evolutivo das subsidiárias, que depende tanto das contingências do ambiente competitivo e da relação entre subsidiárias, como da experiência passada da empresa em suas operações no mercado estrangeiro (REZENDE, 2003).

A abordagem de rede compreende a empresa como uma relação de troca entre diferentes unidades organizacionais, incluindo a matriz, as diferentes subsidiárias nacionais e a estrutura formada por uma 'rede externa'. Essa estrutura é formada por todas as unidades com que a corporação transacional tem que interagir, tais como clientes, competidores, órgãos dores, reguladores e competidores, sendo essa uma perspectiva inter-organizacional. Outra perspectiva é intra-organizacional ou corporativa, denominada por Nohria e Goshal (1997) como redes diferenciadas.

Redes de relacionamento nos mercados estrangeiros desempenham papel importante, tanto para as redes externas como para as internas (BORINI, 2007). Redes externas configuram os relacionamentos com os parceiros de negócios e, encontram-se aí entre outros, os fornecedores. Já a rede interna resulta do relacionamento entre as subsidiárias.

A participação nas redes resulta num dilema. Quando a subsidiária está enraizada no mercado local, menor a sua integração com a rede intra-organizacional, o que implica menor possibilidade de transferência da competência (BORINI, 2007). Se por outro lado, o fato de a subsidiária se encontrar fortemente enraizada na rede do país estrangeiro, permite o acesso a conhecimento tácito e complexo, que não seria adquirido de outra forma, por outro impede sua transferência para outras unidades da rede corporativa, em função da menor ligação entre as subsidiárias e matriz.

Sob o ponto de vista da matriz, a rede intra-organizacional é mais interessante, pois, como exposto no aspecto de integração, o objetivo é tê-la como fonte de competências não-locais. 
Por sua vez, do ponto de vista da subsidiária, o melhor seria uma forte integração com a rede local, porém resultaria menor reconhecimento e alinhamento com a matriz (MINBAEVA, 2003).

A estrutura em rede é um aspecto do determinismo ambiental, visto como um dos aspectos para explicar as origens das diferenças de papéis das subsidiárias. Também a estratégia de rede refere-se a um grupo de empresas relacionadas que trabalham para o bem comum de todas.

Uma das vantagens da estrutura em rede é possibilitar que empresas entrem em alianças estratégicas e em outras formas de parceira, e, assim, obterem acesso a novo conhecimento e outros recursos.

As redes de negócios podem ser analisadas sob duas formas: redes horizontais e verticais. Nas redes horizontais, as empresas concorrentes estabelecem relações entre si, formando alianças estratégicas. Trataremos a seguir do tema das redes verticais.

\subsubsection{Redes Verticais}

Nas verticais, o que se observa é a articulação de fornecedores, distribuidores e compradores que são coordenados por uma empresa que exerce influência sobre os outros membros da rede (MAZZALI; COSTA, 1997).

Segundo Hitt (et al, 1999), são três os tipos de redes:

- Redes estáveis: aparecem freqüentemente em indústrias maduras, como Nike e fornecedores;

- Redes dinâmicas: surgem em indústrias onde rápidas inovações tecnológicas são introduzidas, freqüentemente por causa do curto ciclo de vida dos produtos, como Apple e fornecedores;

- Redes internas: podem ser implementadas para facilitar as operações da empresa, podendo utilizar, como por exemplo, a rede interna para coordenação de compras.

Outras abordagens de rede estão dentro de uma lógica de verticalização ou de empresas que 
se relacionam para atuar nos mesmo elos da cadeia de valor (PORTER, 1986). São redes de relações verticais, que ligam fornecedores a usuários finais, e de relações horizontais, que ocorrem entre competidores atuais ou potenciais e provedores de serviços, como consultores, agências de pesquisa e outros (op. cit.).

Espera-se que as subsidiárias que desempenham atividades de maior valor agregado, como marketing, $\mathrm{P} \& \mathrm{D}$, serviços profissionais, tenham uma percepção mais favorável quanto às redes de negócios no país. Por sua vez, as subsidiárias que tem seu foco de negócios centrado em atividades de baixo valor agregado, como manufatura e vendas, não necessitam de uma rede de relacionamentos tão complexos (OLIVEIRA, Jr. et al, 2009).

Segundo pesquisa com 118 subsidiárias estrangeiras no Brasil (OLIVEIRA, Jr. et al; 2001) mostra que elas apresentam uma concordância fraca em relação a um elevado grau de relacionamento entre compradores e fornecedores, condição necessária para a construção de redes de negócios.

O pressuposto para explicar a baixa percepção das subsidiárias em relação as rede pode ter seus fundamentos na própria estratégia da empresa orientada para a exploração dos recursos e não inovação. Resultado disso é, do lado das subsidiárias, a baixa pro atividade na fomentação e participação em redes de negócios. Do lado dos parceiros externos, o baixo reconhecimento da subsidiária como um parceiro que permite estabelecer uma relação de negócios duradoura e que se comprometa com os resultados e o desenvolvimento das empresas integradas à rede.

Dessa forma, quando a estratégia da multinacional não é orientada para a inovação, é pouco provável que apresente alguma propensão para as redes (OLIVEIRA, Jr. et al; 2009). 


\subsection{Global Sourcing (GS)}

Apresentaremos neste capítulo uma visão geral da literatura enfatizando os principais pontos relacionados à estratégia de Global Sourcing, inicialmente com uma visão geral do que é GS, os estágios e suas características, as dimensões e passos para o desenvolvimento da estratégia, aplicação em mercados emergentes e sinergia utilizando GS,

\subsubsection{Visão geral - o que é Global Sourcing}

Baseada na visão de Resource Based View (RBV) atividades que dividem conhecimento dentro da empresa terão uma função primordial, especificamente, a incerteza ambiental motiva o comprador e fornecedor a engajar em mais atividades de compartilhar conhecimento com cada outro para copiar melhor com as constantes mudanças (CHEUNG, 2005).

No início de 1969, Fayerweather descreveu um modelo conceitual de planejamento de Global Sourcing envolvendo as relações dinâmicas entre fábrica, mercados, produtos, componentes e seus fluxos logísticos. Contudo, poucas pesquisas sucederam até que nos anos 80 estratégia de Sourcing ressurgiu como um importante aspecto na resposta para a competição global.

O termo Global Sourcing (GS) é definido como a maneira mais eficiente de usar os recursos humanos, materiais, energia e capital ao redor do mundo (HEFLER, 1981). Segundo o autor, as estratégias de GS compreenderiam em: (i) encontrar vendedores qualificados para compra de materiais ou produtos; (ii) formar uma relação de joint venture; (iii) fazer um investimento na aquisição de $100 \%$ em um país estrangeiro.

O conceito vem evoluindo ao longo do tempo e a definição mais abrangente de estratégia de Global Sourcing pode ser vista como o gerenciamento das interfaces entre P\&D, produção e marketing em uma base global e de logística identificando quais unidades de produção será servido com mercados particulares e como componentes serão supridos para produção, tais que a firma possa explorar ambos sua própria vantagem competitiva e vantagens 
comparativas de vários países (KOTABE, 1992; McCLINTOCK; 2002).

Envolve ainda a programação da operação da produção em diferentes países para atender diversos mercados, ou comprar e montar componentes, partes ou produtos acabados ao redor do mundo (DAVIDSON, 1982; KOTABE; OMURA, 1989; MOXON, 1975) pela coordenação efetiva das atividades, firmas podem assegurar custos estruturais menores e atingir produtos de melhor qualidade. Com operação em diversos países, empresas multinacionais possuem habilidade de coordenar atividades de produção em escala global para explorar não só vantagens competitivas, mas também vantagens comparativas de diferentes países (MURRAY et al, 1994).

O conceito inclui freqüentemente integração de design ou desenvolvimento e também requisitos do cliente interno localizado em diferentes países. A compra de requisitos combinados de mais de uma unidade ou site de país, fora do país, onde o material ou serviço comprado será usado. Freqüentemente, os requisitos ou especificações são determinados por uma base multifuncional e de diversas localidades (MONCZKA, 2006). Esses requisitos básicos devem estar alinhados previamente ao processo de Global Sourcing. Estes podem incluir especificações de materiais e serviços, usando localizações, volumes, qualidade, entrega flexibilidade e outros.

Global Sourcing refere-se àquelas decisões que determinam quais unidades de produção servirão, quais mercados particulares, e como componentes/produtos acabados/serviços serão procurados (DAVIDSON, 1982; KOTABE, 1992). Operando em múltiplos países, multinacionais tem a habilidade de coordenar atividades em uma escala global para explorar não somente suas vantagens competitivas, específicas da firma, mas também as comparativas, de localidades ou países aonde as empresas conduzem seus negócios (DUNNING, 1988; McCLINTOCK, 2002). Do ponto de vista do McClintock (2002), há três áreas onde o GS pode ser aplicado: compras, produção e interface funcionais de operações.

Sob o ponto de vista de tese de ciclo de vida do produto internacional alguns autores (UTTERBACK 1987; VERNON, 1974) sugerem que, a compra internacional tem início em uma organização a partir do momento que se tem como objetivo a manutenção do custo competitivo. Como os componentes/produtos acabados amadurecem e a competição 
intensifica com o tempo, podemos considerar que nesse momento surge a necessidade de busca de novas fontes/fornecedores que tragam alguma vantagem competitiva a um processo em tese mais estabilizado, iniciando uma nova etapa de compra internacional. Assim, visto do aspecto de ciclo de vida do produto o GS acontece na fase maturidade, quando a organização busca como objetivo a manutenção do custo competitivo.

A importância do lançamento de novos produtos, com ciclos de vida curta, causa em uma firma a colaboração inter-firma com fornecedores estrangeiros, tornando assim uma componente chave para o as estratégias de GS. Em adição, a pesquisa sugere que uma fonte inter-firma pode ressaltar a flexibilidade através de múltiplos fornecedores, pode assegurar de forma contínua a viabilidade de novos fornecedores no futuro, e ajuda a explorar todos os benefícios das condições de mudança do mercado (KOTABE, 1992).

Global Sourcing se difere de compra internacional, pois esta última representa uma transação comercial entre um comprador e um vendedor, localizados em países diferentes. Este tipo de transação é tipicamente mais complexa que uma compra doméstica, além de diferir em escopo e complexidade. Envolvem ainda a integração e coordenação de itens e materiais, processo, desenho, tecnologia, e fornecedores através da compra, engenharia e operações localizadas.

Um aspecto importante refere-se a confiança. Ela impõe uma importante regra na seleção de fornecedores internacionais. Confiança é desenvolvida através de comunicação e experiência, que se torna a construção goodwill. Enquanto empresas em quase toda indústria estão usando fontes de suprimento internacional, muitas ainda confiam em fornecedores domésticos (HEINFIELD, 1994).

É necessário ter uma visão sob a perspectiva integrada do GS para capturar a dualidade que a gerência de compras está crescentemente em confronto quando se está comprando globalmente. Por um lado, fornecedores estão aplicando estratégias globais e isto força os gestores de compras a aumentarem a coordenação e centralização das estratégias de compras, a fim de não enfraquecer o poder de barganha. Já observando por um ângulo diferente, executivos de compras estão cada vez mais conscientes do custo de oportunidade em aplicar estratégias de compras locais: o efeito de volume pode ser limitado e a incompatibilidade entre o foco de compras de subsidiárias pode liderar para solução menos desejada 
(MATTHYSSENS, 2006).

Outras formas que devem ser consideradas, como o fato de produtores competitivos, que independem da sua nação de origem, atuam no mesmo mercado global que os países dotados de recursos naturais. Contudo, em segmentos de produção de alta tecnologia, como eletroeletrônicos, o valor da matéria-prima é um dos menores elementos no custo do produto final entregue para o ponto de venda.

Uma pesquisa conduzida em 1996 pela National Association of Purchasing Mangament (NAPM) e Center for Strategic Supply Management (CAPS) quando foram enviados 2500 questionários com 369 respostas (14,8\%), já indicavam Global Sourcing como uma estratégia importante, considerada pelas empresas americanas e européias. Estando no $23^{\circ}$ lugar em um total de $36^{\circ}$ tendências entre os executivos de compras da América do Norte e Europa (CARTER; NARASIMHAN, 1990).

\subsubsection{Desenvolvimento do Global Sourcing}

\subsubsection{GS operacional e estratégico}

Uma tipologia de GS operacional e estratégico foi desenvolvida por Arnold em 1989. A figura abaixo ilustra quatro dimensões de compras, composto pela combinação do que o autor caracterizou como Operativo somente reagente a demandas, que tem como vértice oposto Estratégico, contribuindo a proteção potencial. No outro eixo compõem as forças de orientação de compras, tendo em cada extremo as compras nacional e internacional.

Surge assim, pela combinação das duas dimensões - operacional/estratégico e nacional/internacional quatro tipologias distintas: (i) operacional: compras tradicionais e expansão regional de mercado; (ii) operacional: Política de Compra going international; (iii) estratégico: área de compras com foco estratégico (como gerenciamento da cadeia): mercado nacional e (iv) estratégico: GS mercado internacional. 
Figura 3 - Global Sourcing como programa estratégico de compras

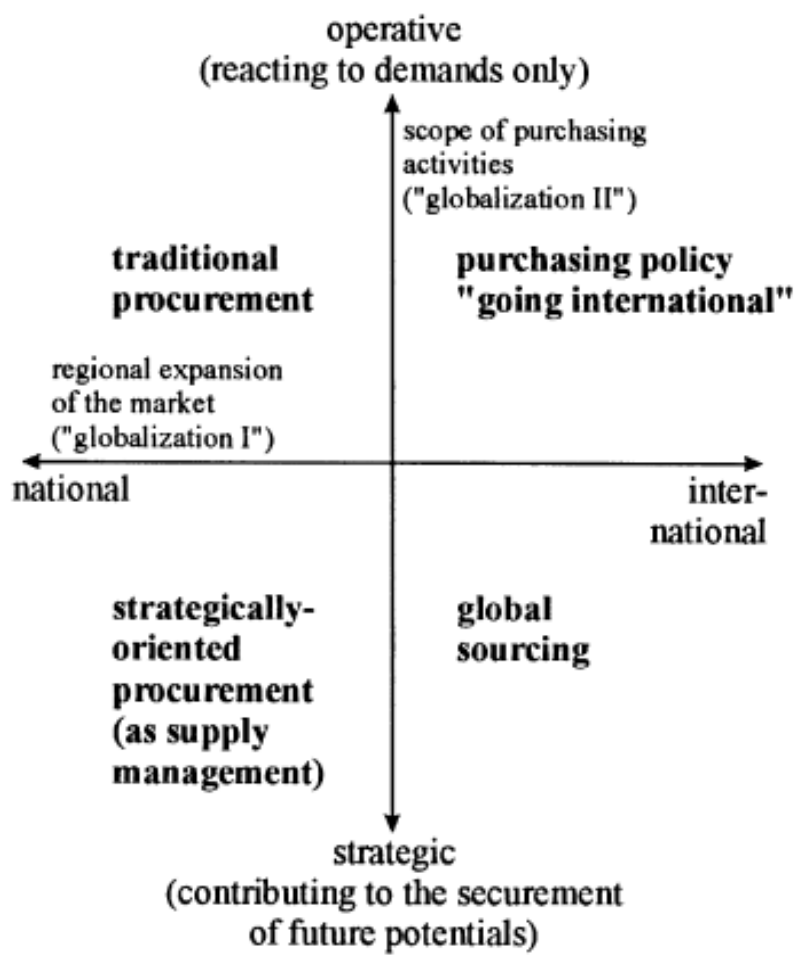

Fonte: ARNOLD, 1989

\subsubsection{Estágios de Global Sourcing}

Através de um projeto de pesquisa exploratório com 162 empresas com faturamento médio superior a US\$1,5 bi de diversas nacionalidades e patrocinado por um consórcio de pesquisa intitulado Global Benchmarking Initiative (GBI) ligada a Michigan Statate University no período de 1993 a 2000, estabeleceu-se uma representação dos estágios do processo de compras nas empresas. As fases do estágio indicam uma perspectiva evolucionária do papel estratégico da área de compras, que tem início com foco no território nacional, para de forma progressiva expandir atuação junto ao mercado internacional, atingindo em última instância o nível de Global Sourcing com integração tanto de localidades quando de grupos funcionais espalhadas pelo mundo.

A figura a seguir apresenta os diferentes estágios assim como a participação das empresas em 
cada uma das fases.

Figura 4 - Estágios do Global Sourcing

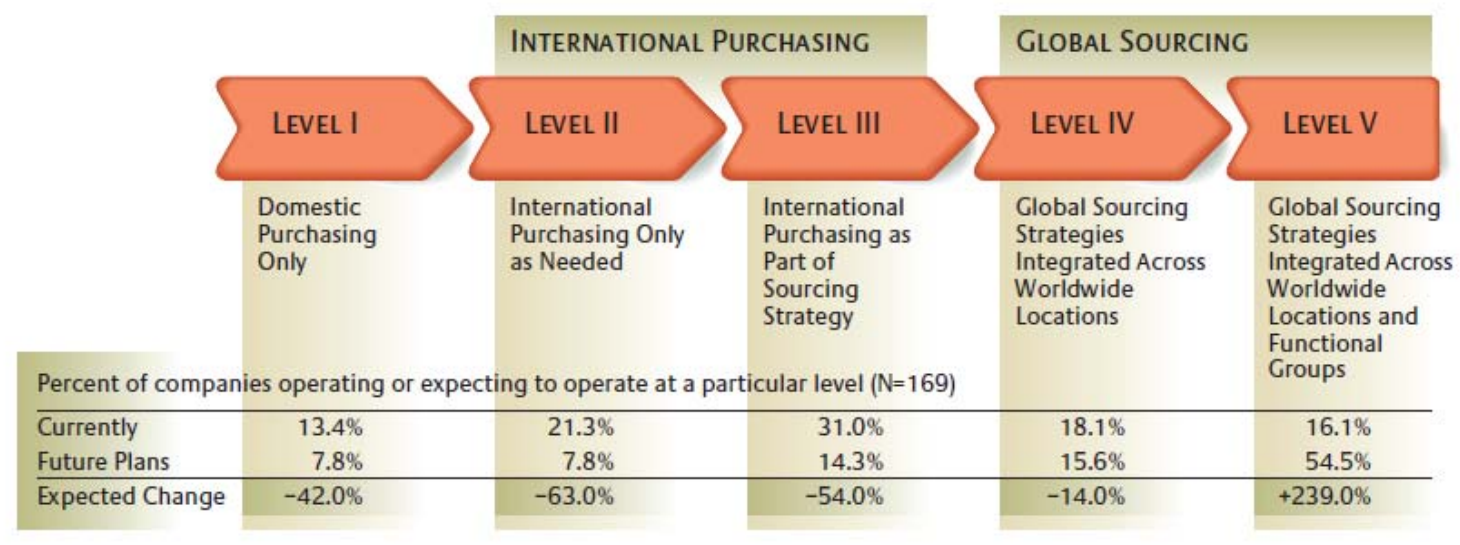

FONTE: MONCZKA; TRENT, 2005.

Nota: Plano Futuro: \% de empresas com expectativa de operar em um nível particular nos próximos três a cinco anos.

\subsubsection{Características dos estágios de compras internacionais até o nível de global sourcing}

Os estágios de compras internacionais desenvolvido por Monczka e Trent (2005), compreendem quatro fases e vão das compras internacionais até o nível de Global Sourcing. As características de cada fase serão apresentadas a seguir.

Na fase 1, as empresas têm como característica básica somente a realização de compras domésticas. Outras características das empresas são: baixa necessidade de informação para compra internacional; falta de informações internacionais sofisticadas e produtos estrangeiros comprados através de fontes domésticas.

As empresas que se encontram na fase 2, realizam as compras internacionais baseadas nas necessidades competitivas. Isso acontece a partir da necessidade; crescente necessidade de informações internacionais; as quais s firmas são geralmente reativas nesta fase e as empresas possuem capacidade de compras internacionais limitada. 
Na fase 3, as empresas apresentam como estratégia para a compra internacional o surgimento de suporte da alta administração para Global Sourcing; as perspectivas globais de potenciais de mercados são analisadas; tem início a inclusão pro ativa de estratégias de aquisição internacional; há uma menor resistência à inclusão de compras internacionais, e os compradores são designados; e subsidiárias, ou escritório de compras internacional (ECI, IPOs,) são usados para compra ao redor do mundo.

No último estágio da área de compras, as empresas têm uma integração estratégia de compras globais apresentando como características: maior captura de benefícios de Global Sourcing; necessidade de informações critica; nível gerencial executivo destinado para coordenar esforço global; integração e coordenação de requisitos de Global Sourcing para maximizar a alavancagem pelo volume de compra; organização completa e sistema de informação integrado e medição Global Sourcing e estabelecimento de sistema de recompensa. 


\subsubsection{Dimensões da Estratégia}

As dimensões da estratégia de Global Sourcing podem ser divididas em duas: aspecto de localização e aspecto de propriedade (KOTABE, 1992), que abordaremos a seguir.

\subsubsection{Localização da produção}

Aspecto de localização: localização do suprimento/fornecedor pode ser de origem do mercado doméstico, ou seja, nacional ou envolver fornecedores estrangeiros. Como é caracterizada a iniciativa, sob os aspectos de autonomia e principalmente a integração entre a matriz e subsidiárias e entre as próprias subsidiárias no fluxo de produtos para a cadeia de valor; doméstico vs. Global Sourcing (MURRAY; KOTABE, 1999).

\subsubsection{Propriedade}

Aspecto de propriedade: compra de componentes se dá através de fornecimento intra e interorganizacional. O interno acontece quando os componentes provêem de dentro do sistema corporativo, ou seja, de uma fonte da própria corporação. Assim, o fornecimento está dentro da propriedade, nas movimentações entre matriz e subsidiária e entre as próprias subsidiárias, chamado sourcing intra-firma. Outra forma de propriedade é a externa, interfirma, isto é, pela aquisição direta com terceira parte, de fornecedores independentes em bases contratuais.

O quadro a seguir resume as características das dimensões do Global Sourcing. 


\section{Quadro 8 - Dimensões do Global Sourcing e características}

\begin{tabular}{|l|lr|c|}
\hline Dimensões & \multicolumn{3}{|c|}{ Característica } \\
\hline Propriedade & $\begin{array}{l}\text { Compra dentro do sistema } \\
\text { corporativo } \\
\text { (internal sourcing), origem de } \\
\text { outras unidades, subsidiárias e/ou } \\
\text { matriz }\end{array}$ & $\begin{array}{l}\text { Compra fora do sistema corporativo } \\
\text { (outsourcing), através de }\end{array}$ \\
\hline $\begin{array}{l}\text { Localização } \\
\text { Fornecedor }\end{array}$ & $\begin{array}{l}\text { Origem nacional ou doméstica: } \\
\text { dentro do país da subsidiária }\end{array}$ & Origem externa: país estrangeiro \\
\hline
\end{tabular}

Fonte: a Autora, com base em KOTABE, MURRAY(2004); MURRAY et al (1995); MONCZKA, TRENT (2004).

\subsubsection{Desenvolvimento de estratégia de GS}

Robinson (1987) sumarizou em cinco passos, contínuos e interativos, o desenvolvimento de uma estratégia de global sourcing através da cadeia de valor:

- Identificar separadamente os elos de cadeia de valor da empresa: P\&D, produção e marketing;

- Determinar a localização das vantagens competitivas da firma, considerando economias de escala e escopo;

- Assegurar o nível de custo de transação entre os elos da cadeia de valor, ambos interno e externo, e selecionar o modo de menor custo;

- Determinar as vantagens comparativas dos países (incluindo os do país de origem da empresa) relativas a cada elo da cadeia e para custos de transação relevantes;

- Desenvolver adequada flexibilidade no processo de decisões corporativas e estrutura organizacional para permitir que a firma responda as mudanças em ambos sua vantagem competitiva e vantagem comparativa de países. 


\subsubsection{Sourcing em mercados emergentes}

\section{Responsabilidade local e flexibilidade de controle}

Para capturar benefícios oriundos de oportunidades dos mercados emergentes, uma reponsividade maior é necessária. A resposta local é o contexto da relação entre matrizsubsidiária, envolvendo o entendimento gerencial, reposta e adaptação para condições do país, para que decisões e políticas pertinentes a subsidiárias sejam administradas considerando parâmetros do ambiente local, como regulações governamentais, dinâmica de competição e cultura de negócios.

Estudo realizado pela consultoria Deloitte (2008), recolheu opiniões de mais de 650 executivos de empresas de todo o mundo e foram analidas a forma como os fabricantes dos mercados desenvolvidos e em vias de desenvolvimento, encaram o risco inerente ao Sourcing nos mercados emergentes - e também as formas como as empresas de maior sucesso gerem este risco e o transformam numa vantagem competitiva.

O Sourcing nos mercados emergentes vem aumentando. Quase três quartos dos executivos dos mercados desenvolvidos incluídos no estudo da Deloitte afirmam ter reforçado o recurso ao Sourcing nos mercados emergentes nos últimos três anos, com quase $50 \%$ a considerar que esse aumento tem sido significativo. Quanto aos países que mais procuram para fornecimentos de componentes e peças, 66\% mencionaram a China, e 36\% México e a América Central. A Europa Central ou de Leste, a Índia e o Sudeste Asiático foram, cada um, mencionados por um quarto ou menos.

Os benefícios podem ir além dos preços e incluir o crescimento da quota de mercado e o reforço das marcas para as empresas dos mercados desenvolvidos. Os fornecedores dos mercados emergentes também podem recolher benefícios. O cumprimento de padrões mais elevados pode também tornar mais fácil atrair e manter clientes de dimensão global, sobretudo quando esses padrões contrastam com os problemas que a concorrência enfrenta nos mercados locais e nos mercados emergentes concorrentes.

Tomando como base a revisão das principais teorias sobre o tema Global Sourcing, e a participação das subsidiárias de multinacionais como agentes atuantes nesse processo, até 
onde temos conhecimento, a proposta de estudo é pioneira e espera identificar as respostas frente às questões apontadas no capítulo de objetivos específicos.

Estudos abordando a relação matriz-subsidiária são importantes para o crescimento da MNE porque eles afetam a forma como as subsidiárias internalizam as atividades globais dentro da organização e também o caminho pela qual a subsidiária de multinacionais individualmente neutralizam as desvantagens enfrentadas face às entidades estrangeiras, incluindo fornecedores, através do fluxo de recursos de outras partes da organização (LUO, 2003).

Obviamente, a decisão de comprar globalmente é um tipo de senso comum, mas a questão é como realizar estes objetivos estratégicos e como organizar global sourcing de forma efetiva ainda não foi respondida (ARLNOLD, U.; 1999).

\subsubsection{Sinergias GS}

Rozemeier (2000:7) define sinergia em compras como: "valor que é adicionado quando duas ou mais unidades de negócios (ou departamentos de compras) juntam suas forças (ex: compra combinada) e/ou compartilha recursos, informações, e/ou conhecimento na área de compras”.

Seguindo essa lógica, GS pode ser dividido em três principais categorias: (1) economias de escala (2) economias de informação e aprendizado e (3) economias de processo (ARNOLD, 1997; ROZEMEIJER, 2000).

As economias de escala referem-se à obtenção de menores custos unitários pelo aumento e poder de mercado, através de volume e padronização de categorias. Economia de informação e aprendizado relacionados a compartilhar informação e conhecimento através de diferentes sites e localidades. Por exemplo, conhecimento de sobre fornecedores, novas tecnologias, aplicações, especificações requeridas e ainda melhores práticas e experiências. Finalmente, economias de processo se relacionam aos benefícios derivados do estabelecimento de um caminho comum de trabalho e troca de melhores práticas de procedimentos de compras 
dentro da companhia (ARNOLD, 1997; FAES ET AL, 2000; ROZEMEIJER, 2000). As empresas somente atingem de forma completa a vantagem do GS quando conseguem obter todos os três tipos de sinergia potenciais (TRAUTMANN et al., 2009).

Para ilustrar os conceitos que acabamos de apresentar, selecionamos um caso abordado por Monczka e Trent (2005) relacionando estratégia de Global Sourcing, seus impactos dentro da estrutura organizacional e resultados obtidos.

\subsubsection{GS na Air Products and Chemicals}

Um exemplo interessante é o da Air Products and Chemicals (MONCZKA; TRENT, 2005), uma empresa americana que projeta e opera gás industrial e instalações químicas no mundo todo. Em 1999, executivos da companhia se surpreenderam com um estudo interno indicando que os custos de operação deveriam ser reduzidos em 30\% para manter a competitividade global. Novos competidores de baixo custo surgiram na Ásia/Pacífico no esforço de melhor desempenho, a gerência concluiu que o Global Sourcing seria a ferramenta que oferecia oportunidades. A empresa historicamente operava num sistema de engineer-to-order, utilizando design customizado e centros de compra. Isso resultou em altos custos de projeto e esforços de compra para cada projeto, bem como falta de coordenação entre as unidades americana e européia.

Pressões do ambiente competitivo compeliram a empresa a coordenar as atividades de design e compras buscando identificação de padronização e sinergia em compras e projetos. Depois de cinco anos de experiência em Global Sourcing e com mais de 100 projetos, a Air Products apresentou uma média de $20 \%$ de redução de custo em relação a fornecedores regionais e práticas de projeto anteriores. Executivos de compras agora trabalham com equipe de marketing para incluir a expectativa de redução de custo proveniente do processo de Global Sourcing do projeto quando respondem a uma proposta comercial. Assim, o Global Sourcing integrado está proporcionando uma nova fonte de competitividade para uma empresa que opera numa indústria madura. 


\subsection{GS e modelo organizacional}

Para realizar as funções de compras com sucesso e de forma eficiente realizando vantagens competitivas, a estrutura de GS deve seguir a estratégia de GS de acordo com as hipóteses de Chandler (1962).

A importância de estudar o nível funcional tem como base o trabalho original de Malnight (1995), que destaca que a globalização ocorre no nível da função. O artigo apresenta o processo de globalização que foi gradualmente se ajustando de onde e como funções importantes, ou tarefas, foram sendo realizadas. Funções envolvidas no processo incluíam P\&D, produção e marketing, em uma empresa farmacêutica. É interessante pensar que a área de compras como área funcional poderia estar inclusa na função produção do caso citado. Os estágios de desenvolvimento foram definidos como participação, contribuição e integração.

Desde esse trabalho de Malnight, os estudos de negócios internacionais têm aumentado foco na integração global, conseguida em funções tais como pesquisa e desenvolvimento (P\&D), marketing ou produção (NOBEL; BIRKINSHAW, 1998). Contudo, a função de compras tem raramente sido o centro das atenções. (TRAUTMANN, 2009).

Nesse aspecto, buscamos com o estudo, tornar mais claro através de um foco específico em analisar dois elementos estruturais pertencentes à grande maioria dos autores do tema de gestão de multinacionais, autonomia e integração, frente à aplicação/forma da estratégia de Global Sourcing.

\subsubsection{Relacionamento Matriz-subsidiárias}

Ao analisarmos como os gerentes poderiam usar os vários instrumentos e processo de forma mais apropriada, Barlett (et al.1992) focaliza duas dimensões da tarefa de coordenação. A primeira envolve a coordenação dos fluxos entre as unidades organizacionais, enquanto a segunda relaciona-se à coordenação dos papéis e responsabilidades estratégicas das unidades. 
Segundo o autor, os fluxos são a alma de qualquer organização, mas de importância particular numa organização transnacional. O primeiro é o fluxo de mercadorias: as interconexões complexas através das quais as companhias buscam sua matéria-prima e outros suprimentos ligam os fluxos de componentes e montagens e distribuem as mercadorias acabadas em toda uma rede integrada de unidades especializadas, de determinadas unidades de abastecimento, de amplas operações de montagem e de subsidiárias de vendas localizadas. O segundo fluxo é o de recursos que englobam não apenas a locação de capital e a repatriação dos dividendos, mas também a transferência de tecnologia e o movimento de pessoal em todo o sistema. $\mathrm{O}$ terceiro é o fluxo de informações: dados brutos, informações analisadas e conhecimento acumulado, que as companhias precisam difundir por toda a rede mundial de unidades nacionais.

As decepções e fracassos que algumas das companhias pesquisadas por Barlett (op. cit.), encontraram que em suas operações internacionais não ocorreram devido à análise estratégica inadequada, mas a deficiências organizacionais (Barlett, 1992).

Nesse sentido, direcionamos dois aspectos que acreditamos venham a impactar nas empresas multinacionais quanto ao seu relacionamento matriz - subsidiária que são os temas de autonomia e integração, que abordaremos a seguir.

\subsubsection{Autonomia}

A autonomia da subsidiária está associada à liberdade que a unidade tem para tomar decisões sem a intervenção da matriz (ROTH; MORRISON, 1992).

Matriz e subsidiária apresentam forças opostas quanto ao controle das decisões. Enquanto a matriz procura controlar as atividades para proteger o seu investimento no exterior, e acima de tudo manter o alinhamento estratégico, a subsidiária, por sua vez, exige maior autonomia para orientar seus negócios face às demandas do contexto competitivo, que por um lado, pode garantir a aderência ao mercado local, mas apresenta risco de descolar da sua estratégia do mercado global. Essa maior autonomia, porém pode garantir a subsidiária melhor adaptação às necessidades do mercado local, fato essencial para criação das inovações e competências 
das subsidiárias (NOHRIA; GHOSHAL, 1997).

Subsidiárias com poucos anos de criação são fortemente dependentes da matriz para suas decisões (DUNNING, 1993) em razão da limitação cognitiva em relação ao país estrangeiro (JOHANSON; VAHLE, 1977).

Segundo os autores Jarillo e Martinez (1990), se de um lado há a subsidiária com alto grau de autonomia da matriz que realiza a maior parte de suas vendas para o mercado e que se abastece de fornecedores basicamente locais; de outro, está à subsidiária interdependente, cuja boa parte de sua produção é para ser negociada intrafirma, ou seja, com a matriz ou outras subsidiárias. Assim, as subsidiárias autônomas seriam aquelas que desenvolvem basicamente todas as funções da cadeia de valor de maneira relativamente independente das demais subsidiárias ou da matriz corporativa.

Um ponto importante refere-se à própria estrutura organizacional, seu grau de centralização, e o quão ela está relacionada com o aspecto da autonomia da subsidiária com a matriz. Exploraremos no próximo tópico a centralização da estrutura da área de compras.

\subsubsection{Centralização da Estrutura}

Problemas organizacionais são dominados por questões do grau de centralização. Como em um fluxo e refluxo, o pêndulo da centralização varia de total centralização para a total descentralização. O conceito de reengenharia de negócios e negócios virtuais está próximo da recomendação de uma estrutura descentralizada. Se quanto menor a centralização, e a formalização da estrutura, melhor será a comunicação entre as unidades e matriz-subsidiárias. A forte relação de trabalho e a constante comunicação são exemplos da fluência dessa comunicação.

Desta forma os problemas organizacionais são dominados pela questão do grau de centralização e em termos de GS (des-)centralização é a variação de elementos de compra (departamento, processos, responsabilidades) dentro de um sistema de GS (ARNOLD; 1999). Em geral: se não há acúmulo destes elementos, o grau de centralização é baixo. 
Com relação à GS, descentralização é uma oportunidade e um risco também. Risco porque a área de compras de uma unidade de negócios/subsidiária pode ser tão pequena para comprar globalmente e de uma forma eficiente. Orientação estratégica de toda a atividade de compras pode ser negligenciada (ARNOLD, 1999).

Por outro lado, descentralização é uma oportunidade porque pode fazer mais fácil cruzar fronteiras e estabelecer unidades de negócios com função de compras em países estrangeiros. A descentralização também pode estimular competição interna entre subsidiárias. Em outras palavras, o espírito do empreendedorismo pode ser uma grande vantagem, mas as desvantagens de pequena ou média empresa (especialmente menores efeitos de escala) são também desvantagens para sistema de centro de lucro. Os autores Matthyssens e Faes sumarizam as vantagens e desvantagens no quadro abaixo:

\section{Quadro 9 - Argumentos em favor da Descentralização e Centralização da Estrutura para Global Sourcing}

\begin{tabular}{|c|c|}
\hline Argumentos em favor da descentralização & $\begin{array}{l}\text { Argumentos em favor da } \\
\text { centralização }\end{array}$ \\
\hline $\begin{array}{l}\text { 1. Responsabilidade da gerência local por } \\
\text { todos os custos incluindo compras pode } \\
\text { se tornar frustrada se eles perdem } \\
\text { controle sobre um item importante de } \\
\text { custo }\end{array}$ & $\begin{array}{l}\text { 1. Posição negocial mais forte frente aos } \\
\text { fornecedores, gerando melhores preços e } \\
\text { condições gerais. }\end{array}$ \\
\hline $\begin{array}{l}\text { 2. Cooperação entre compradores locais e } \\
\text { usuários. Bom arranjo para atender } \\
\text { necessidades locais }\end{array}$ & $\begin{array}{l}\text { 2. Construção de um grupo estratégico de } \\
\text { compras. Uniformidade lidera a economia } \\
\text { de escala }\end{array}$ \\
\hline $\begin{array}{l}\text { 3. Escolha de fornecedores locais: } \\
\text { a. Serviços melhores e mais rápidos } \\
\text { b. Menores tempos de entrega } \\
\text { c. Reputação com comunidade local }\end{array}$ & $\begin{array}{l}\text { 3. Aquisição de conhecimento do mercado } \\
\text { mais profunda e melhor. Estabelecimento } \\
\text { de uma visão de suprimento global. }\end{array}$ \\
\hline 4. Compradores locais mais motivados & 4. Uso eficiente das habilidades de compras \\
\hline & $\begin{array}{l}\text { 5. Menos trabalho administrativo e redução } \\
\text { das despesas de organização de compras }\end{array}$ \\
\hline
\end{tabular}

Fonte: Matthyssens e Faes (S/D). 
As subsidiárias não podem mais competir como uma coleção de subsidiárias nacionalmente independentes, uma vez que a competição está aumentando, baseada na habilidade da firma para integrar as atividades das subsidiárias através da localização geográfica (BARTLETT; GHOSHAL, 1989; KOTABE; MURRAY, 2004; NOHRIA; GHOSHAL, 1997; PORTER, 1986). Nesse contexto, para atingir a eficiência global, a reponsividade local e aprendizado global são competências vitais para a competitividade segundo Barlett et al. (2004).

Utilizando como base o modelo conceitual criado por Arnold (1999), podemos visualizar uma perspectiva geral organizacional de toda a companhia que pode ser transferida para a organização de GS. O objetivo é responder não somente como organizar a própria estrutura de GS, mas também como definir o grau de centralização de GS com respeito à (i) melhor forma para a estrutura interna dentro da organização (ii) melhor formato de estratégia de GS e estratégia internacionalização geral e (iii) melhor ajuste de toda estrutura e estratégia.

A metodologia combina pesquisa analítica e empírica (figura A). Primeiro o autor desenvolveu um modelo geral para analisar as empresas dependendo do grau de internacionalização, e seu grau de centralização ambos de forma geral e em compras. Isso resultou em oito tipos diferentes condensados em uma matriz de duas dimensões.

Em seguida, a matriz permite posicionar estudos de caso em nove empresas. Foi possível identificar diferentes grupos na matriz de combinação internacionalização/centralização.

\subsubsection{Modelo de estrutura para GS}

A figura abaixo apresenta o procedimento utilizado pelo autor para propor a tipologia envolvendo estratégia e estrutura para global sourcing. 
Figura 5 - Procedimento pesquisa para tipologia estrutura Global Sourcing

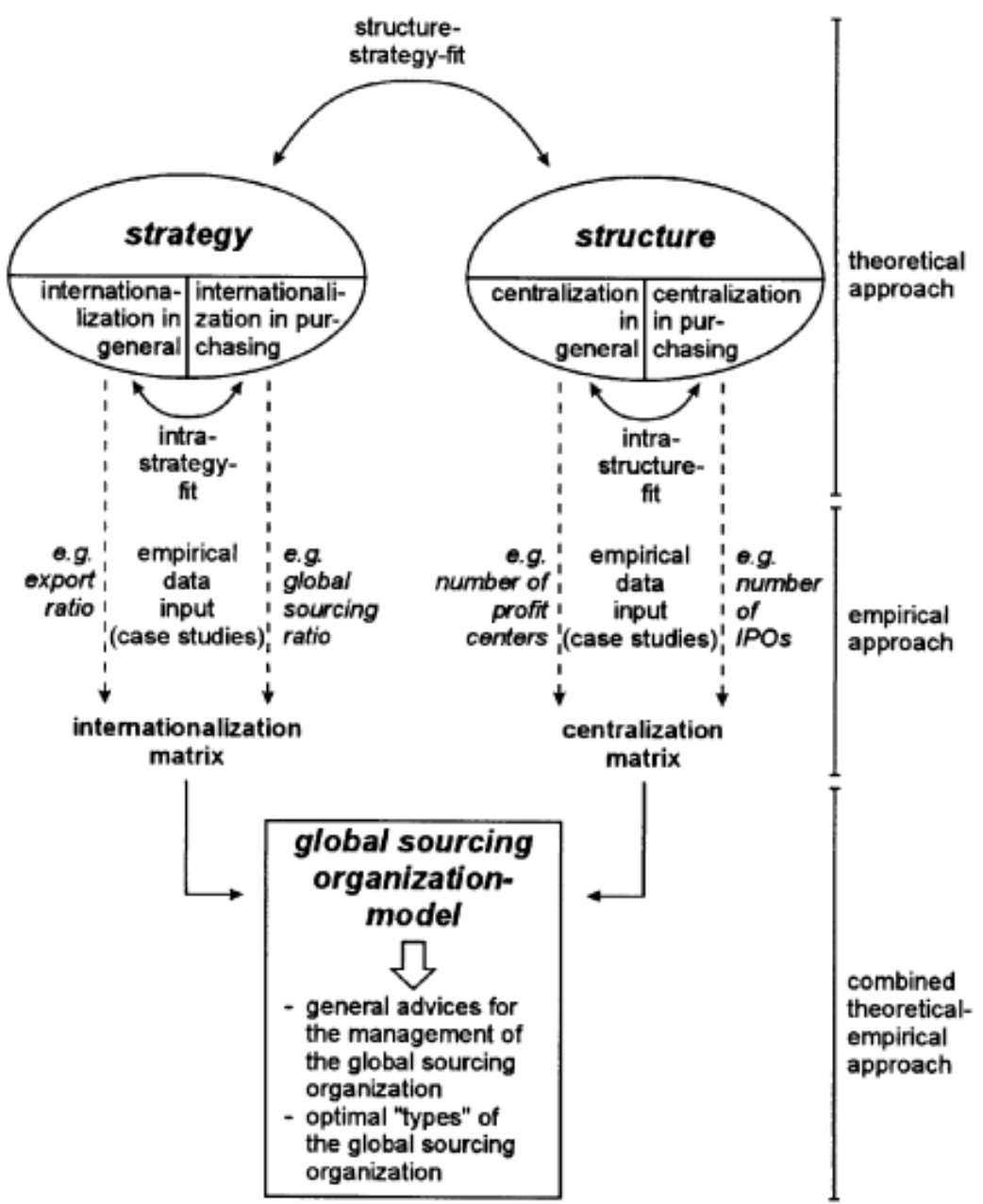

Fig. 3. Research procedure.

Fonte: Arnold, 1999

Para encontrar o melhor ajuste dentro da estrutura de uma organização e sua estratégia (figura 5), o modelo analítico adotou quatro dimensões (figura 6): primeira internacionalização é descrita em duas dimensões: a internacionalização geral e a internacionalização de compras. Segundo, estes dois níveis (toda a empresa e da função compras) são examinados analisando o seu grau de centralização. Como resultado, quatro tipos de organização podem ser identificados em cada matriz de internacionalização e centralização.

O player global tem atividades internacionais em todos os campos incluindo compras (tipo A na figura 6), empresa doméstica (tipo D na figura 6) não é orientada internacionalmente em 
nenhuma atividade da cadeia de valor. Uma mistura de companhia geralmente internacional com uma baixa relação de GS é chamada "GS déficit” (tipo C, fig.6). O GS foco tipo B combina baixo interesse em atividades internacionais em geral com um alto índice de GS (“on the way”).

A matriz de centralização combina os graus de centralização em organizações em geral com o grau de centralização da estrutura de compras. Na estrutura hierárquica (tipo 1 na figura 6) estes dois graus são altos, na "estrutura atomizada” (tipo 4 na figura. 6) ambas as graduações são baixos. Uma companhia altamente centralizada com uma função de compras altamente centralizada é chamada “estrutura compras hierárquica” (tipo 2, figura. 6), aonde a “estrutura compras atomizada” (tipo 3, figura. 6) combina uma organização geral centralizada com uma gestão compras descentralizada.

O passo seguinte da análise de GS combina o resultado da matriz de internacionalização e o resultado da matriz de centralização em uma tipologia de duas dimensões. Com o instrumento de classificação é possível mostrar diferentes posições de uma análise de empresas empiricamente.

A ilustração a seguir apresenta a combinação de duas matrizes. Na primeira, a matriz leva em consideração dois aspectos, de internacionalização da empresa de uma forma geral e das compras, com variações dessas duas vertentes, o autor criou a tipologia de uma empresa global, empresa com foco em Global Sourcing, empresa com déficit em Global Sourcing e empresa doméstica. Na segunda matriz, as variáveis são centralizações da empresa de uma forma geral e centralização das compras. A tipologia resulta em empresas com estrutura hierárquica, estrutura de compras hierárquica, estrutura de compras diminuta e estrutura diminuta. A partir da combinação das duas matrizes, de grau de internacionalização e de centralização, em ambas com eixos para empresa em geral e especificamente para área de compras, surge uma terceira matriz. Esta posiciona a empresa num quadrante final de internacionalização e centralização já consideradas a graduação da empresa como um todo e a de GS. 


\section{Figura 6 - Modelo analítico para organização de Global Sourcing}

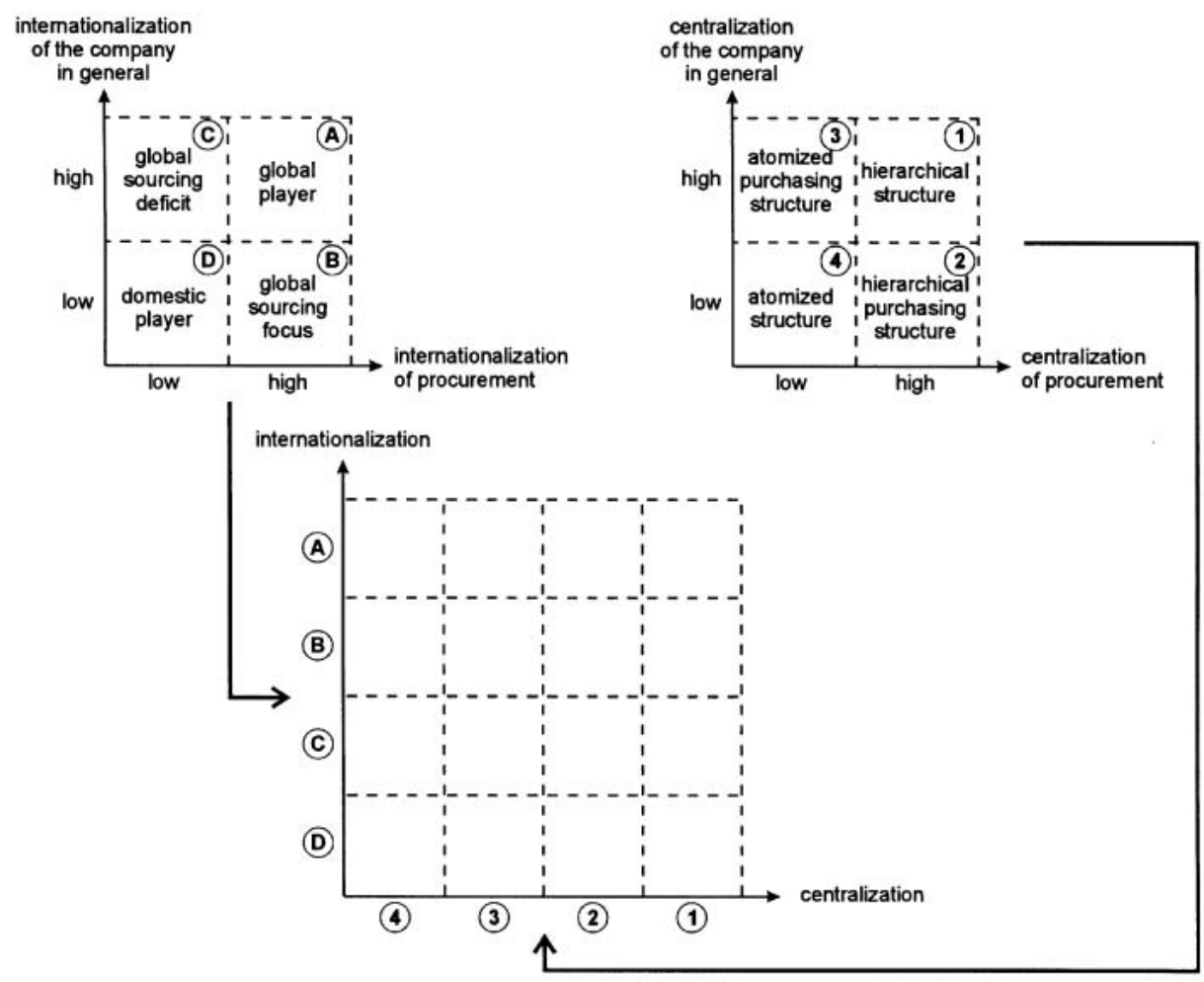

Fig. 4. Analytical model for the global sourcing organization.

Fonte: Arnold, 1999

Com base em uma pesquisa abrangendo múltiplos países liderados pelo Center for Advanced Purchasing Studies (CAPS) em Tempe, Arizona, Arnold (op. cit.) apresenta alguns estudos de caso de empresas líderes na Alemanha, destacadas como referência de melhores práticas na área de gestão de fornecimento (supply chain management), para analisar da área de compras assim como o modelo empregado na estrutura da área de compras.

Para ilustrar o modelo analítico proposto apresentaremos um resumo das empresas estudadas, a seguir, são elas: Sony Eletronics, Porshe, Muller Weingarten, Mercedes-Benz, ZF, Opel, Hewlett Packard, BASF. 


\subsubsection{Modelos organizacionais de GS}

Para melhor ilustrar o modelo desenvolvido por Arnold (1999) apresentaremos os modelos organizacionais da tipologia desenvolvidos pelo autor. Serão abordados os casos investigados das empresas Sony Electronics, Porsche, Muller Weingarten, Mercedes-Benz, ZF e BASF.

\section{Sony Electronics}

Sony Corporation é um produtor mundial de eletrônicos para entretenimento (hard e software). Seu escritório é localizado no Japão e a subsidiária alemã registrou faturamento em 1995 da ordem de 2.5 bilhões DM, com volume de compras de cerca de 1 bilhão de DM (SONY CORPORATION, 1995:29). A Sony estabeleceu uma matriz-organização dentro de sua estrutura de compras (SONY CORPORATION, 1994: 8). Na parte horizontal, unidades de negócios independentes têm total responsabilidade para uma categoria de produto específico, como eletrônicos móveis ou semicondutores.

Cada unidade de negócios tem dois tipos de departamento de compras: uma unidade central que é responsável por toda atividade de compras durante a fase de $\mathrm{P} \& \mathrm{D} /$ engenharia, o departamento de compras descentralizado responsável por todo o fornecimento para as plantas produtoras que eles são estão conectados. No eixo vertical, as unidades de negócios são sobrepostas por uma estrutura regional a qual divide a região em Japão, Ásia, América do Norte e Europa. Nessas regiões, as atividades de compras de forma geral são realizadas por escritórios de compras regionais.

Como apresentado, a estrutura geral e a de compras, são majoritariamente descentralizadas em muitas diferentes unidades organizacionais. Sony tem uma estrutura atomizada (tipo 4 na figura 6). Por outro lado, a empresa é altamente internacionalizada (player global tipo A); por exemplo, 85\% dos elementos passivos (por ex. resistors) são comprados de países não europeus. As atividades de GS são gerenciadas e realizadas por escritórios denominados Escritórios de Compras Internacional (ECI). Os ECIs não são partes da Sony Electronics: eles têm sido terceirizados e administrados pela Sony Trade Corporation. Então, o departamento de compras usa os ECIs como um serviço externo de negócios. 


\section{Porsche}

A empresa Porche é uma companhia muito centralizada (tipo estrutura hierárquica 1, na figura. 6) e aproximadamente todas as atividades de produção são concentradas em uma única planta produtora. Entre 80 e 90\% do volume de compras é administrado por um departamento de compras central. Itens de menor interesse (menor valor, menor volume, etc), estão sob a responsabilidade do departamento de produção e reposição (compras da fábrica).

Negócio da Porsche é altamente internacionalizado. No ano fiscal de 1994/1995, a Porsche exportou 69,5\% dos carros para países fora da Alemanha. No mesmo período, somente $10 \%$ do volume total de compras foi adquirido globalmente. A principal razão pode ser a falta de uma infra-estrutura internacional de compras (não possuem ECIs). Assim, a Porsche apresenta claramente um déficit de GS (tipo C na figura 6).

\section{Muller Weingarten}

Comparada com a maioria dos outros estudos de caso, Muller Weingarten é uma empresa menor. Em 1995, faturamento foi da ordem de 398 milhões DM e seu volume de compras na ordem de 203 milhões de DM. (MULLER WEINGARTEN AG, 1996: 58).

No entanto, a empresa é líder de mercado no segmento de produção de prensas. As prensas são normalmente feitas sob medida para todos os tipos de compradores industriais, especialmente produtores de carros. A empresa concentra seu know how em duas plantas fabris. E, para cada localização um escritório de compras foi estabelecido. Estes escritórios são unidades organizacionais e administradas por uma central de gestão de compras. O tipo de centralização não é típico para outras funções de negócios. Portanto a Muller Weingarten em uma centralização tipo 2 com uma estrutura de compra hierárquica.

\section{Mercedes-Benz}

Na época da pesquisa, a Mercedez-Benz era uma unidade separada dentro do grupo DaimlerBenz, responsável por todas as atividades de carro e caminhões. Em 1995, o faturamento alcançou cerca de 72 bilhões DM com uma exportação de 58,5\% (mais que a média da indústria automobilística de 56,5\%; MERCEDES-BENZ AG, 1996: 71). Além disso, a 
empresa tem 23 plantas produtoras estrangeiras e 14 plantas de montagem.

A proporção de GS é de $20 \%$ do volume total de compras e aponta o déficit em Global Sourcing da empresa (tipo C na figura 6). Embora Mercedes-Benz seja dividida em dois negócios - carros de passageiros e veículos comerciais - a companhia é altamente centralizada. As compras para itens não relacionadas ao produto são centralizadas dentro de toda a empresa, compras de partes produtivas é centralizada no nível da unidade de negócios. Embora, a empresa tenha uma estrutura hierárquica (tipo centralizado 1, na figura 6).

Como resultado da fusão entre Daimler-Benz e Chrysler Corp, a estrutura organizacional tem sido alterada, ou será modificada num futuro próximo. Área de compras é uma das poucas funções as quais foi centralizada imediatamente depois da decisão de fusão. Isto aumenta o impacto estratégico de compras em todo o negócio da DaimlerChrysler. Mas a estrutura final das atividades de compras ainda não estava clara até o momento da pesquisa, segundo relata o autor.

\section{ZF}

Em contraste com a Mercedez-Benz, a ZF é uma empresa altamente descentralizada. O faturamento, como um dos principais fornecedores indústria automotiva, foi de cerca de 6, 4 bilhões de DM em 1994. Cada uma das 32 plantas ao redor do mundo, são centros de lucro e tem estabelecido seu próprio departamento de compras. Esta estrutura atomizada (tipo 4, figura 6) é vantajosa por causa de sua flexibilidade, mas tem desvantagens porque é quase impossível obter ganhos com economias de escala. A ZF decidiu estabelecer uma organização baseada por centro de lucro em função de flexibilidade, e habilidade em motivar o gerenciamento centro de lucro. Ao dar responsabilidade pelo lucro aos gerentes dos centros, foi necessário estabelecer uma organização de compras descentralizada. Sem compras, o gerenciamento não poderia ser responsável pela maior parte dos custos de produção.

A ZF tem um alto grau de descentralização, 22 dos 32 locais de produção estão fora da Alemanha, sua taxa de exportação é maior que 45\% em 1994 (ZF FRIERICHSHAFEN AG, 1995: 4/14). GS é o maior objetivo da “Core Strategy Purchasing” da ZF. Desta forma, os escritórios de compras das fábricas da ZF em países estrangeiros atuam como um centro de 
serviços externo para os departamentos de compras alemãs. Em todos os países sem uma unidade produtora, o departamento de compras central tem um mandato para aquisição, em sua maioria realizada com chamados compradores corporativos. Assim, a ZF constitui segundo o autor, uma empresa realmente global (tipo A na figura 6).

\section{Opel}

A empresa é uma subsidiária da maior empresa produtora de veículos mundial General Motors (GM). Dentro da rede GM, a Opel é responsável por todas as atividades de engenharia fora do mercado norte americano. A taxa de exportação é de mais de $52 \%$ do total das vendas de 25,9 bilhões de DM, a relação de GS é cerca de 45\% do volume total de compras de 17,8 bilhões de DM.

Tipicamente, os departamentos de compras regionais são diretamente relacionados com as unidades produtivas de todas as subsidiárias estrangeiras. A coordenação é gerenciada pela então denominada Comitê de Compras Europeu (CCE). As solicitações de aquisição são feitas pelo departamento local, a última decisão é feita somente pelo Comitê de Compras Europeu.

Todo departamento local envia um representante para o Comitê que se encontra semanalmente. Todas as decisões do Comitê são obrigatoriamente para todo o grupo Opel. Esta estrutura hierárquica (tipo 1, figura 6) pode ser achada em outras funções também. Por exemplo, todas as atividades engenharia são gerenciadas pelo Centro Técnico de Engenharia na matriz da Opel localizada na Alemanha.

\section{Hewlett Packard}

A HP planeja, produz, e vende produtos e sistemas em computação, comunicações e técnicas de medição. Localizada em Paolo Alto/EUA, sua subsidiária HP alcançou um faturamento de 8,8 bilhões de DM em 1995. As exportações alcançaram 56,7\% do total faturado, o GS está perto de $80 \%$ do volume total de compras. Não há dúvida que HP é uma empresa global (tipo A na figura 6). 
Por outro lado, a HP tem uma estrutura predominantemente atomizada (tipo 4 na figura A), com mais de 60 unidades de negócios que podem atuar completamente independente, e são denominadas como centro de lucro. Toda unidade tem seu próprio escritório de compras. A central de compras chamada HPP (Hewlett-Packard Purchasing), e escritórios de compras internacionais (ECI ou International Procurement Offices, IPOs) atuam como centro lucro e oferece seus serviços para os departamentos de compras das unidades.

\section{BASF}

Basf é caracterizada por uma matriz organizacional dividindo a corporação em unidades de negócios (responsáveis pela estratégia de produto e tecnologia mundial em seus negócios, como fertilizantes, por ex.), e divisão de países (responsável pelas táticas de produto e mercado e assim como resultados de negócios em uma região definida). Compras de matérias primas são centralizadas como uma unidade de negócios. Desse modo, a Basf é caracterizada como uma estrutura hierárquica tipo 2 (na figura 6).

Embora trabalho da BASF seja a de um negócio altamente internacionalizado (73\% do faturamento de 46,2 bilhões DM, em 1995 foi obtido fora da Alemanha), a empresa tem um déficit de GS (tipo C na figura 6).

As compras de matérias primas foram da Europa é menor que 25\% do volume de compras. Mas para melhor entendimento é necessário notar que o alto grau de rede interna de produção em uma escala internacional. Assim, um grande volume de itens necessários produção de plantas alemãs são supridas por outras companhias localizadas fora do país.

\subsubsection{Matriz com posicionamento dos modelos organizacionais de GS}

A figura abaixo, apresenta o posicionamento das empresas estudadas na matriz de internacionalização e centralização, assim como o modelo de compras utilizado. 
Figura 7 - Posicionamento do modelo organizacional de GS

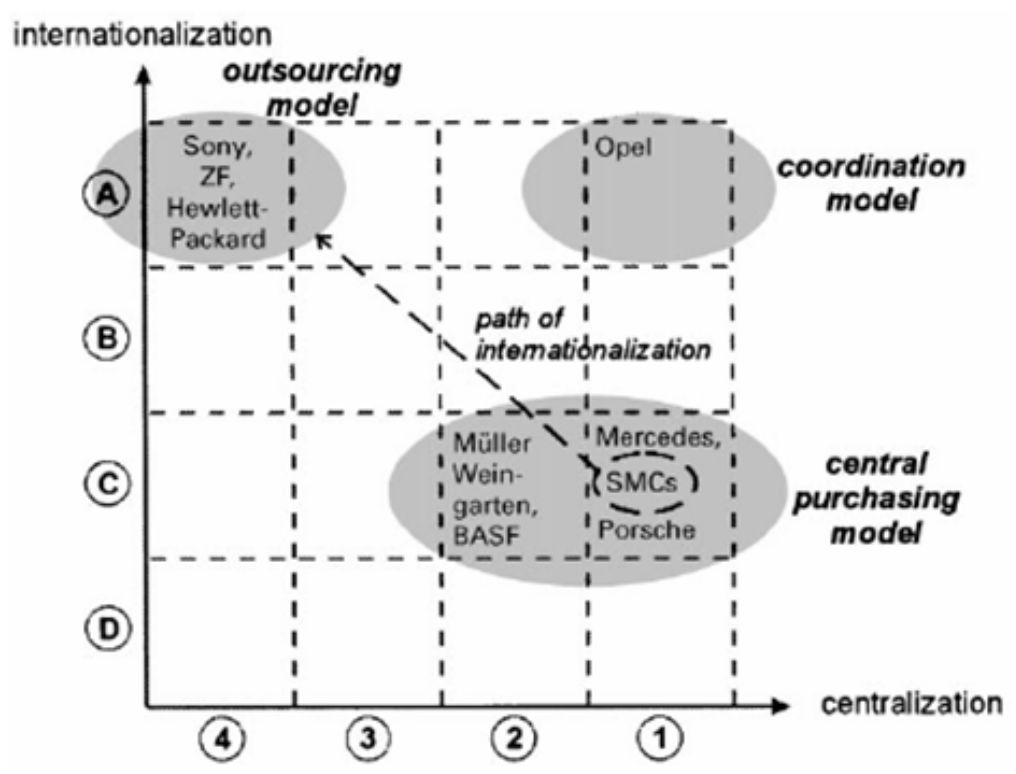

Fonte: ARNOLD, 1999.

\subsubsection{Três tipos ideais de organização de GS: modelo de compras central, modelo terceirizado e modelo de coordenação}

As posições de avaliação de estruturas de compras global empiricamente formaram três grupos, na figura 7 acima. Estes grupos podem ser denominados como alternativas para organização de GS, servindo como modelos de organização geral de GS referindo-se a diferentes graduações de centralização.

O modelo de compras central é útil para organizações que geralmente tem poucas atividades de GS e um alto grau de centralização. Por causa da baixa relação de GS, uma estrutura de compras descentralizada regionalmente não faz sentido. A compra centralizada ajuda a obter economias de escala e de escopo pelo estabelecimento de um processo central de compras. Centralização, desse modo, refere-se não necessariamente a todas as funções de compras, mas pelo menos no gerenciamento centralizado do fornecedor e gestão do contrato.

Modelo de coordenação também faz uso da economia de escala. Ao invés de uma forte 
hierarquia outro sistema é usado. O modelo eficiente para centralização refere-se à idéia de cooperação entre as unidades de negócios. Um exemplo desse modelo de coordenação é o Comitê de Compras Europeu (CCE) da Opel; sendo responsáveis pelas maiores decisões de compras especialmente GS. Todo departamento regional de compras (localizado nas subsidiárias ao redor do mundo) manda um representante para CCE. Esta participação gera uma forte coordenação sem uma forte hierarquia. Este modelo é apropriado para empresas internacionalmente centralizadas. Combina as vantagens de unidade de negócios regional independente com os melhores know how de mercado e as vantagens de demanda em compras. Criando um alto comprometimento para coordenar compras em todas as regiões.

O modelo de terceirização faz sentido em uma empresa altamente descentralizada, mas com forte orientação para internacionalização. Sua principal idéia é possibilitar a autonomia e descentralização da unidade de negócios e suas funções de compras para aquisições de forma global. A terceirização nesse caso é dar um mandato de compras para fornecimento de um específico mercado estrangeiro, para a unidade de negócios localizada lá (modelo ZF) ou estabelecer uma organização de comércio internacional (modelo Sony) o qual atua separadamente. A posição da organização de GS depende fortemente da habilidade para vender GS atividades para unidades de negócios independentes. Sem seu comprometimento, o GS nunca poderia ser terceirizado com sucesso.

\subsubsection{Integração}

Cabe citar que no artigo de Malnight (1992) a integração é considerada a última fase do processo de globalização, movimento que envolve uma única organização global integrada. Como as subsidiárias já teriam aumentado sua experiência e competências, e com trocas entre as unidades expandidas, a oportunidade emerge para integrar unidades de operação espalhadas pelo mundo, fortalecendo não somente as operações internacionais, mas também as domésticas. A integração está relacionada com o compartilhamento de valores entre as unidades, facilitando a compreensão e o relacionamento entre matriz e subsidiárias. São fundamentais para a integração, a comunicação e a socialização (NOHRIA; GHOSHAL, 1997). 
A socialização também é outro elemento que facilita e incrementa a integração. Ela reflete a formação do capital social dentro da organização, são as formas de controle da integração organizacional por meio das redes de contatos pessoais entre membros da empresa. Ela permite que as pessoas possam acessar os capitais da empresa - físico representado pelos recursos - e, o humano - habilidades individuais. Quanto maior o número de contatos de uma pessoa na rede de relacionamentos da empresa, maior o capital social (NOHRIA; GHOSHAL, 1997).

\subsubsection{Difusão do conhecimento como fator estratégico em empresas multinacionais}

Em face de nova conjuntura mundial e sem fronteiras, caracterizados pela velocidade da disseminação e do uso da informação, a capacidade de transferência de conhecimentos deve ser um fator estratégico fundamental para as empresas que competem globalmente. Elas podem estar mais bem preparadas para compreender, planejar e dar respostas para este ambiente de elevada competitividade.

O conhecimento, segundo a definição de Prussak e Davenport (1998) é:

“Uma mistura fluida de experiência condensada, valores, informação contextual e insight experimentado, a qual proporciona uma estrutura para a avaliação e incorporação de novas experiências e informações. Ele em origem e é aplicado na mente dos colaboradores. Nas organizações, ele costuma estar embutido não só em documentos ou repositórios, mas também em rotinas, processos, práticas e normas organizacionais.”

O conhecimento é um produto social, não consensual, que emerge por meio da interação e não deve ser confundido com informações ou dado dentro da organização. Conhecimento pode ser visto como informações repletas de experiência, julgamento, insight e valores (HITT; IRELAND; HOSKISSON, 2003). Na condição de dados dotados de pertinência e objetivo, a informação tem valor competitivo para as organizações. A informação se desenvolve para transformar-se em conhecimento mais pertinente competitivamente quando é usada para estabelecer ligações capazes de gerar valor no mercado. 
Nonaka e Takeuchi (1995) definem que o conhecimento flui e se transmuta através da empresa por meio de quatro processos que se inter-relacionam, conforme demonstrado na figura 8.

A ilustração abaixo apresenta a seqüência para o desenvolvimento e transferência de conhecimento.

Figura 8 - Desenvolvimento e transferência de conhecimento

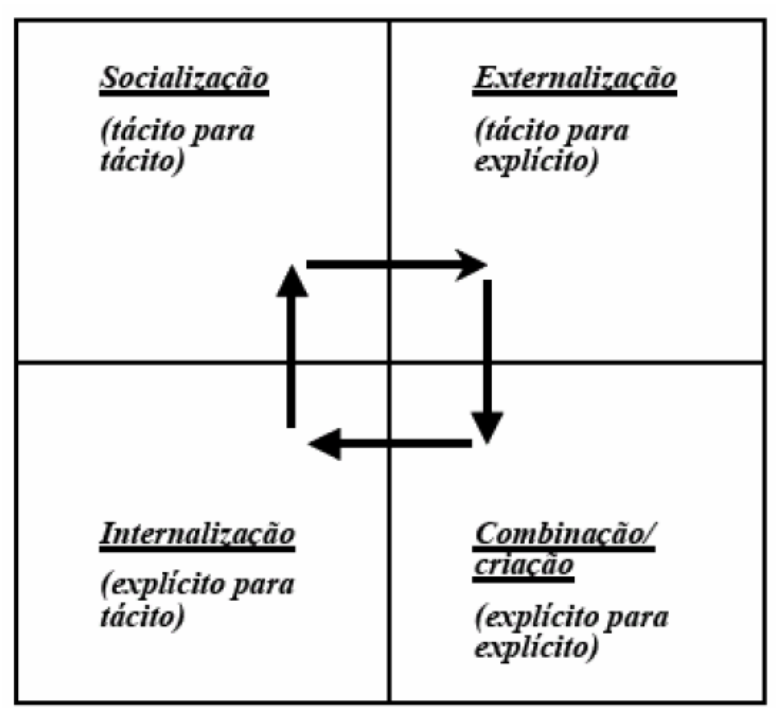

Fonte: Nonaka e Takeuchi (1995)

A socialização é o processo de comunicação do conhecimento tácito de uma pessoa para outra; a externalização é o processo utilizado para converter o conhecimento tácito em explícito; a combinação é o processo de estudo de dois conjuntos de conhecimentos que cada indivíduo detém, com a finalidade de integrar os conjuntos exclusivos de conhecimento tácito para explícito para serem compartilhados por toda a empresa; internalização é o processo de absorção pelos empregados dos conhecimentos explícitos gerados pelo processo de socialização, externalização e combinação. Esses conhecimentos explícitos servirão de base para a geração de novos conhecimentos tácitos, dando início a um novo ciclo do processo da administração do conhecimento.

Nohria e Goshal (1997) desenvolveram um modelo intra-organizacional que objetiva recombinar o conhecimento disperso dentro da organização, para proporcionar às empresas 
realizar seu potencial de criação de valor e inovação. A matriz atribui diferentes graus de valor para cada subsidiária, conforme sua contribuição para a vantagem competitiva da multinacional. Chamada de rede diferenciada, a relação entre matriz e subsidiárias não é uniforme, o que requer uma complexidade gerencial maior para sua administração. A questão da autonomia e integração é importante, mas pode ser alterada. Uma subsidiária pode apresentar-se fortemente integrada com a matriz e ter baixa autonomia, enquanto outra pode ter elevada autonomia e ser pouco integrada.

Figura 9 - Esquema de estrutura de uma multinacional como uma rede diferenciada, sob a ótica do modelo transnacional

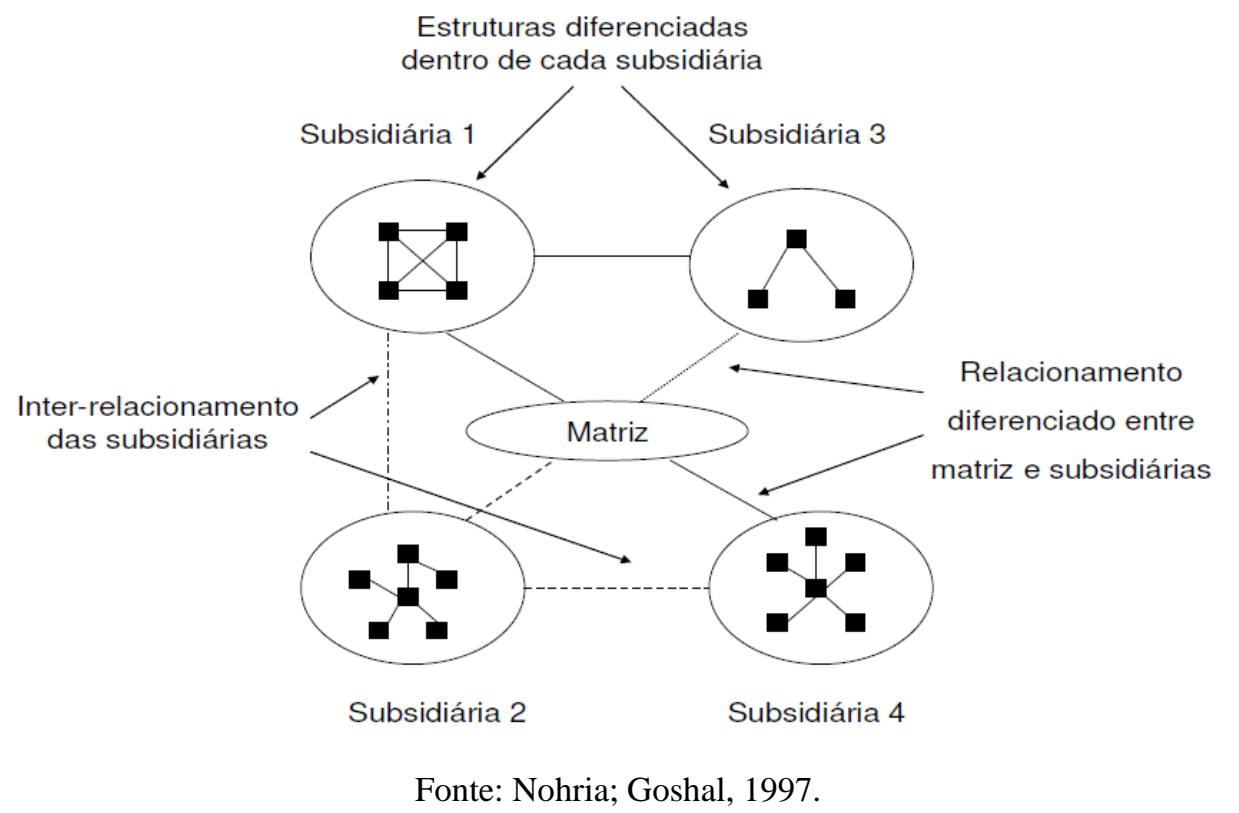

A relação matriz-subsidiária pode variar dependendo da natureza da interdependência em cada situação. Apesar da posição hierárquica que a matriz ocupa na rede, pode variar o grau de independência nas diferentes decisões tomadas.

Embora o modelo seja complexo na sua gestão, é inegável sua contribuição à exploração das competências da multinacional em diferentes localidades, ou seja, para que a multinacional possa usufruir de vantagens competitivas dispersas pela organização.

Outros autores também compartilham de que, quanto mais forte a relação entre matriz e 
subsidiárias menores são as chances de rejeição de projetos das subsidiárias, e a possibilidade de desinvestimento se torna mais difícil (BIRKINSHAW; MORRISON, 1995). Quanto mais forte a relação de trabalho e o grau de integração normativa entre matriz e subsidiária, menor a chance de a subsidiária trabalhar desalinhada das estratégias corporativas, ou aquém das competências essenciais para manter sua posição estratégica dentro da organização (BIRKINSHAW; MORRISON, 1995; NOHRIA; GHOSHAL, 1997).

Assim, quanto mais forte a integração, mais propenso é o cenário para o desenvolvimento de competências, pois há maior confiança da matriz na subsidiária e aquela percebe as possibilidades de desenvolvimento de competências não-locais fora dos paises de origem. Isso possibilita o envio de investimento destinado ao desenvolvimento de competências nas subsidiárias, pois estas representam um local confiável para funções estratégicas corporativas.

\section{Quadro 10 - Estratégias de multinacionais e os elementos estruturais enfatizados em cada configuração}

\begin{tabular}{|c|c|c|}
\hline $\begin{array}{l}\text { Estratégias de } \\
\text { corporações } \\
\text { multinacionais }\end{array}$ & Autonomia & Integração \\
\hline Multidoméstica & $\begin{array}{l}\text { Ênfase central: autonomia alta } \\
\text { para as subsidiárias que } \\
\text { atuavam como unidades } \\
\text { independentes }\end{array}$ & $\begin{array}{l}\text { Ênfase central: baixa no sentido } \\
\text { de transferência } \\
\text { competências, mas importante } \\
\text { para o controle das operações }\end{array}$ \\
\hline Global & $\begin{array}{l}\text { Ênfase central: autonomia } \\
\text { baixa em virtude das } \\
\text { subsidiárias serem réplicas da } \\
\text { matriz }\end{array}$ & $\begin{array}{l}\text { Ênfase central: essencial para a } \\
\text { transferência de competências da } \\
\text { matriz para as subsidiárias }\end{array}$ \\
\hline Transnacional & $\begin{array}{l}\text { Diferenciada, conforme a } \\
\text { atribuição do papel } \\
\text { estratégico da subsidiária. }\end{array}$ & $\begin{array}{l}\text { Diferenciada, conforme a } \\
\text { atribuição do papel estratégico } \\
\text { da subsidiária. }\end{array}$ \\
\hline
\end{tabular}

Fonte: BORINI; 2008 


\section{HIPÓTESES}

A partir da elaboração do referencial teórico, foram definidas as hipóteses que orientaram a realização da pesquisa de campo. Foram formuladas dois blocos de hipóteses, sob a perspectiva dos aspectos de autonomia da subsidiária em relação à matriz e pela integração entre matriz e subsidiária, e relacionados às dimensões de compra de Global Sourcing.

A seguir apresentamos as hipóteses do estudo.

\subsection{Autonomia}

Foram elaborados duas hipóteses relacionados à autonomia. São elas:

H1a: Quanto maior a autonomia da subsidiária, menor a possibilidade de compra de fonte interna, isto é, da subsidiária receber compras realizadas pela matriz e/ou outras subsidiárias e transferidas para a subsidiária (transferência inter-organizacional).

H1b: Quanto maior o grau de autonomia da subsidiária, maior a compra oriunda de fonte externa, ou seja, de fornecedores localizados tanto no mercado local como internacional.

\subsection{Integração}

Duas hipóteses relacionadas à integração serviram de base para a pesquisa de campo:

H2a: Quanto maior o grau de integração da subsidiária, maior a possibilidade da compra de 
fonte interna (transferência interfirma).

H2b: Quanto maior o grau de integração da subsidiária, menor a possibilidade da realização das compras de fonte externa.

O modelo abaixo apresenta o relacionamento dessas hipóteses e das variáveis.

5.3 Modelo da Abordagem de Global Sourcing nas subsidiárias brasileiras de multinacionais.

Figura 10 - Modelo da Abordagem de Global Sourcing nas subsidiárias brasileiras de multinacionais

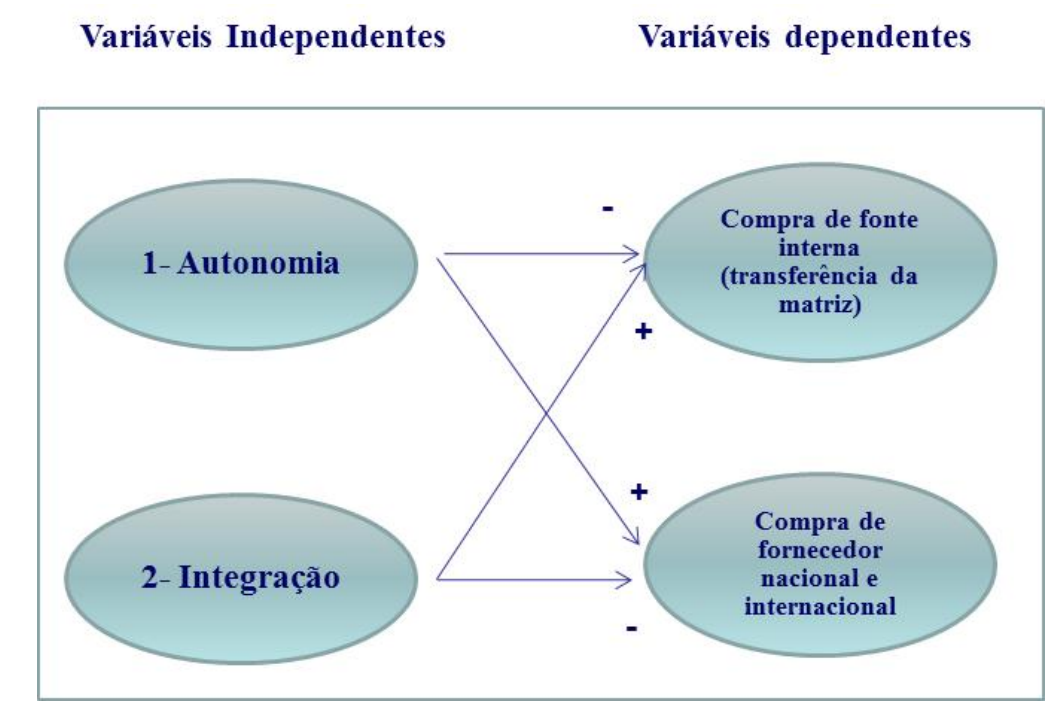

FONTE: a Autora 


\section{METODOLOGIA}

\subsection{Tipo de pesquisa}

O estudo utilizará a metodologia de pesquisa descritiva. Este tipo de pesquisa analisa um fenômeno ou situação mediante um estudo realizado em determinado espaço-tempo. Permite analisar de forma detalhada uma determinada situação/problema ou fato, e relacionar as variáveis (MARTINS; THEOFILO, 2000). O estudo tem como situação problema, identificar como a gestão das subsidiárias de corporações multinacionais no Brasil quanto à autonomia e integração, interfere na aquisição de matérias-primas, componentes sob a ótica de Global Sourcing.

O processo de pesquisa será quantitativo e com a coleta de dados, sendo analisados por meio de testes estatísticos. O Survey foi usado para procurar explicar as razões e as fontes de eventos, assim como suas características e correlações.

\subsection{Seleção da amostra}

A população da pesquisa são as multinacionais estrangeiras com atividades manufatureiras ou de serviço profissional localizadas no Brasil. Para a seleção da amostra foi considerada a relação das 1.200 maiores subsidiárias de corporações multinacionais que atuam no Brasil, pelo critério de valor de vendas. A base de dados dessas empresas foi obtida através da Análise Editorial.

Destas, foram 181 empresas que responderam à pesquisa o que representou uma taxa de resposta em torno de $15 \%$. 


\subsection{Coleta de dados}

O período de coleta aconteceu no último trimestre do ano de 2009. O questionário foi escolhido por ser um instrumento de coleta de dados associados a métodos positivistas, e usado comumente em surveys de larga escala (COLLIS; HUSSEY, 2006), e as perguntas usadas foram fechadas (COLLIS; HUSSEY, 2006; COOPER; SCHINDLER, 2006).

O questionário foi o desenvolvido com base no questionário utilizado no trabalho dos autores Oliveira JR. e Borini (2009), e ampliado para questões específicas do tema GS em foco. O questionário compreende em 37 questões, agrupadas em cinco dimensões. As questões são do tipo escala de Likert, como ela consiste de afirmações que expressam atitudes favoráveis ou desfavoráveis, em relação ao objeto de interesse estabelecemos uma escala de 1 (escore baixo) a 5 (escore alto).

O questionário foi enviado por meio de correio eletrônico (e-mail), para as empresas com as devidas explicações sobre os objetivos da pesquisa e a forma de preenchimento via eletrônica. No intuito de aumentar o retorno dos respondentes, foram enviadas mensagens, via e-mail de follow-up, sensibilizando os respondentes potenciais sobre a importância da participação e para as maiores empresas da lista foram realizados contatos telefônicos, reforçando a relevância da pesquisa. O questionário foi aplicado a gestores que estão, diretamente e indiretamente, relacionados à atividade de gestão de Global Sourcing nas empresas.

\subsection{Perfil das empresas pesquisadas}

A amostra é composta predominantemente por empresas de origem européia, compondo a maioria de 58\%, e por empresas de origem americana, com 29\%. As da Ásia e América Latina correspondem a respectivamente, $6 \%$ e $5 \%$.

Em relação ao setor de atuação das empresas que compõem a amostra, a grande maioria é do 
setor industrial (77\%), enquanto o setor de serviços (21\%) e agro negócio (3\%) compõem o restante das empresas.

\section{Figura 11 - Distribuição das subsidiárias de multinacionais da amostra por setor produtivo}

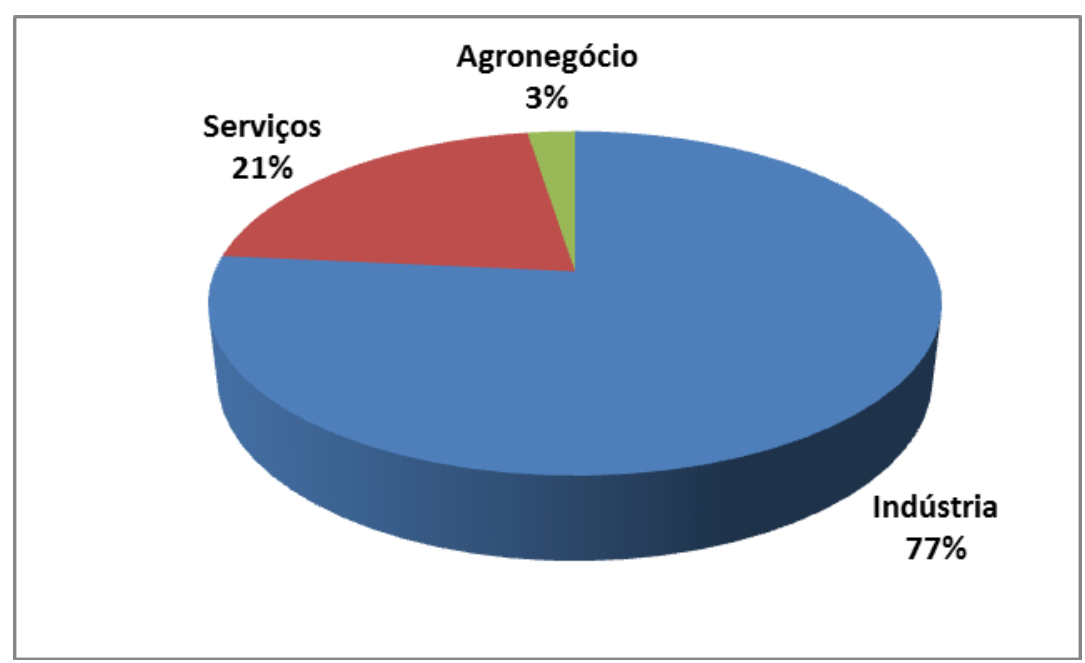

Fonte: autora com base no resultado da pesquisa

O modo de entrada da subsidiária no Brasil na grande maioria foi através de processos de criação de nova empresa (Greenfield), 57\% das empresas, seguida pela forma de aquisição com $31 \%$ e por joint ventures, que representou $11 \%$ da amostra das empresas pesquisadas.

Com relação ao tamanho das empresas, a grande maioria, ou seja, 41\% possuem mais que 500 funcionários, 36\% das empresas tem entre 100 e 500 funcionários e o restante das 23\% empresas possuem menos que 100 funcionários.

\subsubsection{Importância Estratégica}

A questão avalia se a subsidiária é considerada pela matriz como uma subsidiária estrategicamente importante. Conclui-se que as empresas pesquisadas são consideradas de alta importância estratégica para a matriz. 
Figura 12 - Importância estratégica das subsidiárias

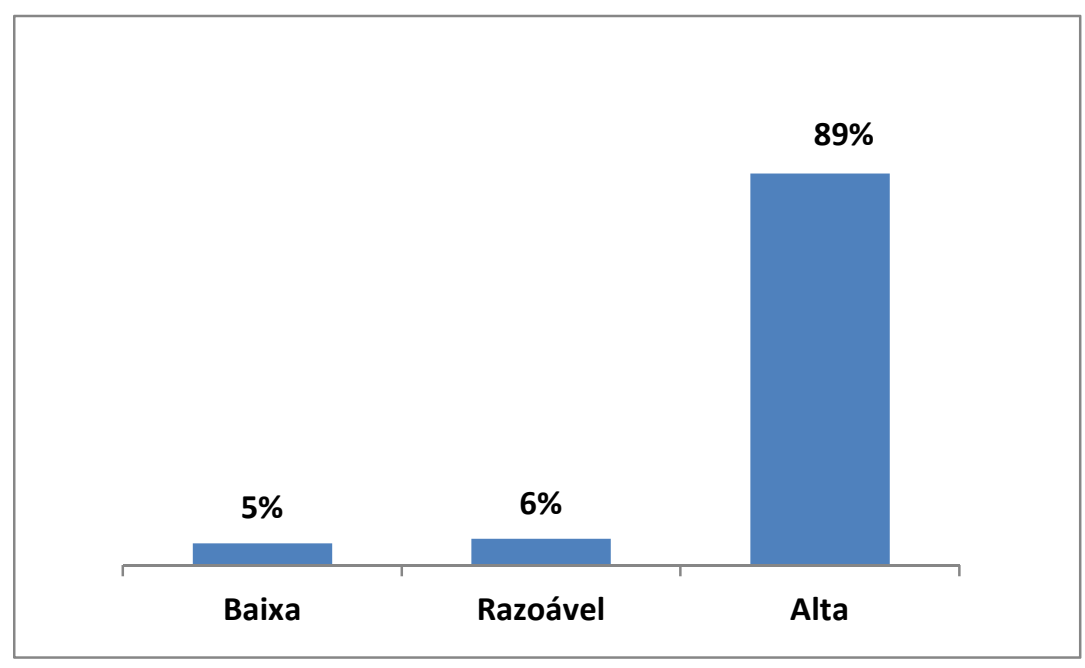

Fonte: autora

\subsubsection{Globalmente Competitiva}

Nessa questão, a empresa responde se é competitiva globalmente na área de atuação.

A grande maioria (73\%) respondeu que considera alto o grau de competitividade global.

Figura 13 - Nível de competitividade global

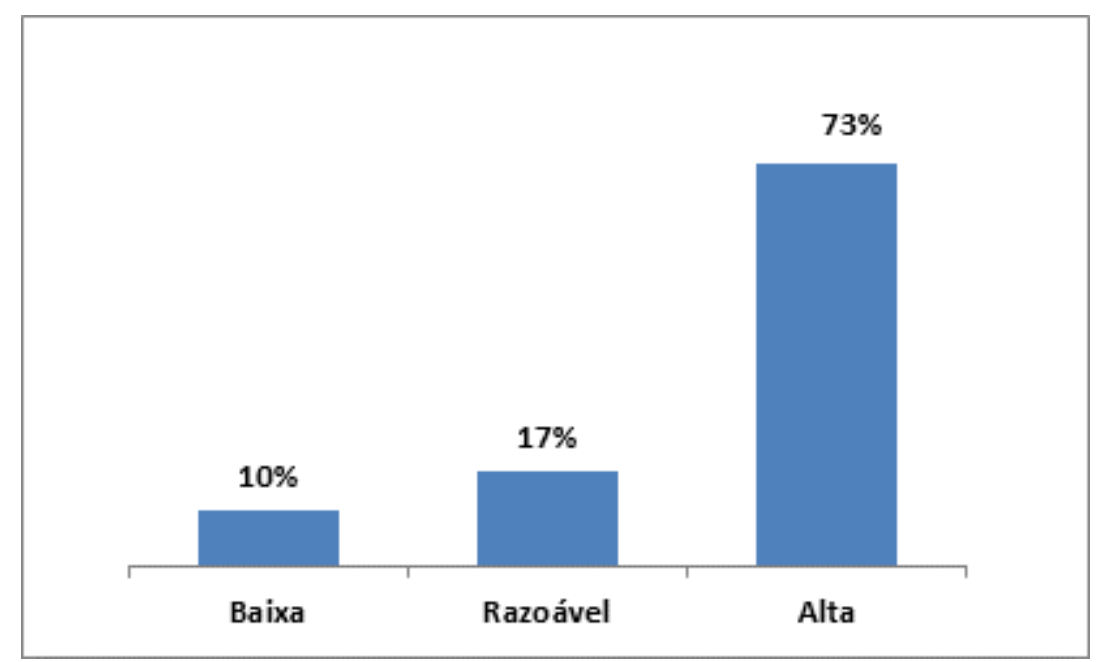

Fonte: autora 


\subsubsection{Importância do Fornecedor}

Em resposta a questão sobre a importância dos fornecedores e parceiros, tanto os brasileiros quanto mundiais foram considerados de importância alta, com respectivamente, 75\% e 64\%. Esse é um fator chave, pois ratifica a relevância dos fornecedores pelas subsidiárias brasileiras. Em relação ao ambiente de negócios de sua subsidiária, aponte qual a importância dos fatores abaixo para o bom desempenho dos negócios da sua subsidiária.

\section{Quadro 11 - Importância dos fornecedores para o desempenho dos negócios da subsidiária.}

\begin{tabular}{|l|c|c|c|}
\hline & Baixa & Razoável & Alta \\
\hline $\begin{array}{l}\text { fornecedores e } \\
\text { parceiros brasileiros }\end{array}$ & $6 \%$ & $18 \%$ & $75 \%$ \\
\hline $\begin{array}{l}\text { fornecedores e } \\
\text { parceiros mundiais }\end{array}$ & $10 \%$ & $27 \%$ & $64 \%$ \\
\hline
\end{tabular}

Fonte: a Autora

\subsubsection{Regiões de comando que sua subsidiária tem relação as função de compras}

Com relação às regiões de comando da função de compras, claramente, a concentração de respondentes tem o Brasil como região de comando para atividade de compras, das empresas participantes da pesquisa. Em segundo lugar, a região da América Latina. É bom ressaltar que as empresas responderam mais de uma região, sendo o total de respondentes, daí o percentual superar a totalidade de $100 \%$. 
Figura 14 - Regiões de comando que a subsidiária tem relação com a função de compras

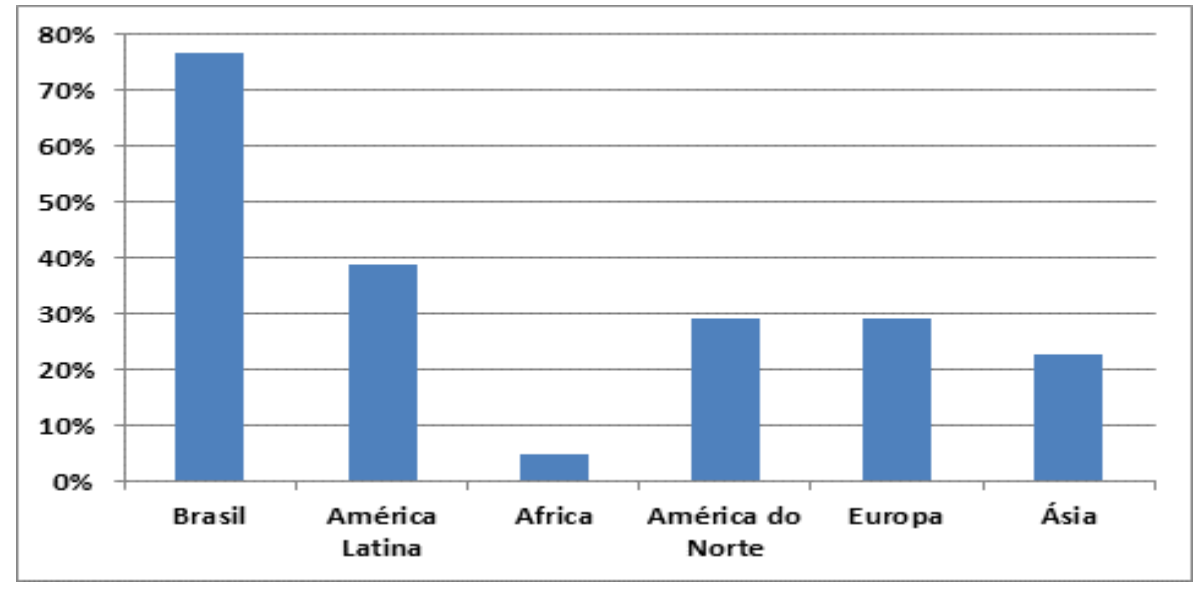

Fonte: a Autora

\subsection{Construção das variáveis de pesquisa}

Variável independente (X) é aquela que influencia, determina ou afeta outra variável: é fator determinante, condição ou causa de determinado resultado, efeito ou consequência, enquanto a variável dependente (Y) consiste nos valores (fenômenos, fatores) a serem explicados ou descobertos, em virtude de serem influenciados, determinados ou afetados pela variável independente; é a algo que foi manipulado pelo fator que aparece, desaparece ou varia à medida que o investigador introduz ou modifica a variável independente; a propriedade ou fator que é efeito, resultado, consequência ou resposta a algo que foi manipulado (variável independente). Em uma pesquisa, a variável independente é o antecedente e a variável dependente e o consequente. Os cientistas fazem predições a partir de variáveis independentes para variáveis dependentes; quando, ao contrário, querem explicar um fato ou fenômeno encontrarão - variável dependente - procuram à causa - variável independente. (MARCONI; LAKATOS, 2005: 140). 


\subsubsection{Variáveis dependentes}

A primeira variável dependente do modelo foi à transferência das compras da matriz para a subsidiária que é composta pela variável de propriedade (KOTABE; MURRAY 2004; MONCZKA, 2006), que pode acontecer pela compra de fonte interna, transferência da matriz e/ou de outra subsidiária ou de fonte externa, através de empresa fornecedora.

A segunda variável dependente está relacionada ao aspecto da localização da produção (KOTABE; MURRAY 2004; MONCZKA, 2006), e assumidos no estudo como sendo localização do fornecedor, já que a premissa é de que a produção está baseada na localização da subsidiária, nesse caso, em território nacional. Assim, investiga-se a compra de fornecedor nacional ou internacionais sendo as questões relacionadas à condição da subsidiária realizar um grande número de compras de fornecedores localizados no país da matriz ou de fornecedores de outros países.

\subsubsection{Variáveis Independentes}

\subsubsection{Constructo Autonomia}

A variável independente de autonomia foi construída pelas seguintes variáveis (BIRKINSHAW; HOODE; JONSSON, 1998): responsabilidade de executar importantes projetos corporativos; desenvolvimento produtos/processos organizacionais em parceria com fornecedores e que hoje são adotados em outras subsidiárias; desenvolvimento de novos fornecedores e parceiros e realização de compras para matriz e outras subsidiárias. O Alpha de Cronbach é de 0,652.

\subsubsection{Constructo Integração}

A variável independente integração foi construída pelas seguintes variáveis (BIRKINSHAW; HOODE; JONSSON, 1998): influência da matriz nas compras; desenvolvimento e transferência de práticas de compra para matriz e/ou subsidiárias e relacionamento com a 
matriz: forte relação de trabalho troca de conhecimento, constante viagem de executivos na matriz, número de expatriados no Brasil.

O Alpha de Cronbach é de 0,725. 


\section{APRESENTAÇÃO E DISCUSSÃO DOS RESULTADOS DA PESQUISA DE CAMPO}

\subsection{Análise Descritiva dos Resultados}

O objetivo deste capítulo é realizar uma apresentação descritiva das variáveis que compõem o modelo proposto. Inicia-se com a descrição das variáveis independentes, seguida da descrição das variáveis dependentes.

Como a escala tem uma variação de cinco pontos, em que o maior grau é maior quanto maior a pontuação, as variáveis são apresentadas segundo uma distribuição de apenas três categorias, para melhor visualização dos resultados: baixa graduação para as respostas da escala 1 e 2; razoável para a resposta 3; alta para as respostas 4 e 5.

\subsubsection{Análises das variáveis do modelo de gestão}

\subsubsection{Autonomia}

O resultado geral, na última coluna, apresenta a média de, 58\% das subsidiárias no Brasil com elevada autonomia. As decisões mais descentralizadas referem-se às de responsabilidade em executar importantes projetos corporativos, ocorre em 83\%. No desenvolvimento de novos fornecedores e parceiros a decisão das subsidiárias é alta e ocorre em 88\% dos casos.

Por outro lado, dois temas apresentaram menor representatividade no quesito autonomia. A realização de compras para matriz e outras subsidiárias, registrou o índice de $41 \%$ das respostas como baixa autonomia, 29\% das empresas responderam ser razoável, enquanto 30\% responderam alta autonomia na realização de compras para a matriz ou outras subsidiárias. O segundo tema que apresentou resposta fraca (35\%) foi o desenvolvimento de 
produtos/processos organizacionais em parceria com fornecedores e que hoje são adotados em outras subsidiárias.

A tabela 1 apresenta a freqüência das distribuições para cada componente da variável.

Tabela 1: Autonomia das subsidiárias estrangeiras no Brasil

\begin{tabular}{|c|c|c|c|c|c|}
\hline & $\begin{array}{l}\text { Responsabilidade de } \\
\text { executar importantes } \\
\text { projetos corporativos }\end{array}$ & $\begin{array}{l}\text { Desenvolvimento } \\
\text { produtos/processos } \\
\text { organizacionais em } \\
\text { parceria com } \\
\text { fornecedores e que hoje } \\
\text { são adotados em outras } \\
\text { subsidiárias }\end{array}$ & $\begin{array}{l}\text { Desenvolvimento } \\
\text { de novos } \\
\text { fornecedores e } \\
\text { parceiros }\end{array}$ & $\begin{array}{l}\text { Realização de } \\
\text { compras para } \\
\text { matriz e outras } \\
\text { subsidiárias }\end{array}$ & Autonomia \\
\hline Baixa & $7 \%$ & $35 \%$ & $6 \%$ & $41 \%$ & $22 \%$ \\
\hline Razoável & $10 \%$ & $34 \%$ & $5 \%$ & $29 \%$ & $20 \%$ \\
\hline Alta & $83 \%$ & $31 \%$ & $88 \%$ & $30 \%$ & $58 \%$ \\
\hline Mediana & 18 & 55 & 10 & 50 & 33,25 \\
\hline Média & 59,33 & 54,00 & 55,00 & 54,67 & 55,75 \\
\hline Desvio Padrão & 62,74 & 2,16 & 64,35 & 8,81 & 34,51 \\
\hline
\end{tabular}

Fonte: a Autora

\subsubsection{Integração}

A análise dos resultados referente às variáveis de integração, e exibidos na tabela 2 mostra a freqüência das distribuições para cada componente da variável. Agrupadas em três categorias: fraca integração para os que assinalaram 1 e 2; integração relativa para os que assinalaram 3; forte integração para os que marcaram 4 e 5.

Os resultados apresentam que há uma forte integração (67\%), com destaque para a forte confiança da matriz na subsidiária apontado por $87 \%$, forte troca de conhecimento (85\%) e forte relação de trabalho (79\%).

Examinando as respostas dadas a componente de influência da matriz nas compras, podemos verificar que ela é forte (41\%), embora os percentuais estejam mais diluídos também nas categorias fraca e razoável. Enquanto o desenvolvimento e transferência de práticas de compra para matriz e/ou subsidiárias teve como avaliação concentrada no quesito regular (35\%) e baixo (34\%). 
Tabela 2: Integração das subsidiárias estrangeiras no Brasil

\begin{tabular}{|c|c|c|c|c|c|c|c|}
\hline & $\begin{array}{l}\text { Influência da } \\
\text { matriz nas } \\
\text { compras }\end{array}$ & $\begin{array}{l}\text { Desenvolvimento } \\
\text { e transferência } \\
\text { de práticas de } \\
\text { compra para } \\
\text { matriz e/ou } \\
\text { subsidiárias }\end{array}$ & $\begin{array}{l}\text { No } \\
\text { relacionamento } \\
\text { da matriz com a } \\
\text { sua subsidiária } \\
\text { existe forte } \\
\text { relação de } \\
\text { trabalho } \\
\end{array}$ & $\begin{array}{l}\text { No relacionamento } \\
\text { da matriz com a sua } \\
\text { subsidiária existe } \\
\text { forte troca de } \\
\text { conhecimento }\end{array}$ & $\begin{array}{l}\text { relacionamento } \\
\text { da matriz com a } \\
\text { sua subsidiária } \\
\text { existe constante } \\
\text { viagem de } \\
\text { executivos para } \\
\text { matriz } \\
\end{array}$ & $\begin{array}{l}\text { No } \\
\text { relacionamento da } \\
\text { matriz com a sua } \\
\text { subsidiária existe } \\
\text { forte confiança da } \\
\text { matriz na sua } \\
\text { subsidiária }\end{array}$ & Integração \\
\hline Baixa & $28 \%$ & $34 \%$ & $6 \%$ & $5 \%$ & $9 \%$ & $2 \%$ & $14 \%$ \\
\hline Razoável & $31 \%$ & $35 \%$ & $15 \%$ & $10 \%$ & $14 \%$ & $10 \%$ & $19 \%$ \\
\hline Alta & $41 \%$ & $31 \%$ & $79 \%$ & $85 \%$ & $78 \%$ & $87 \%$ & $67 \%$ \\
\hline Mediana & 51 & 57 & 24 & 17 & 22 & 17 & 31,3 \\
\hline Média & 54,67 & 55,00 & 27,67 & 54,33 & 53,67 & 54,33 & 49,94 \\
\hline Desvio Padrão & 8,96 & 2,83 & 16,13 & 59,28 & 50,55 & 62,22 & 33,33 \\
\hline
\end{tabular}

Fonte: a Autora

\section{1.2 Análises das variáveis da decisão estratégica de Compras}

7.1.2.1 Compra dentro do sistema corporativo (intrafirma ou transferência) ou fora do sistema corporativo, através de fornecedor (outsourced)

A análise da variável representativa de transferência verificou que as subsidiariam realizam um grande número de compras da matriz ou de outras subsidiárias, e a transferência intrafirma na avaliação é positiva (45\%). 
Tabela 3: Transferência - compra de fonte interna (transferência)

\begin{tabular}{|l|c|}
\hline & $\begin{array}{l}\text { Sua subsidiária realiza } \\
\text { um grande número de } \\
\text { compras da matriz ou de } \\
\text { outras subsidiárias }\end{array}$ \\
\hline Baixa & $38 \%$ \\
\hline Razoável & $18 \%$ \\
\hline Alta & $45 \%$ \\
\hline Mediana & 60 \\
\hline Média & 53,33 \\
\hline Desvio Padrão & 18,57 \\
\hline
\end{tabular}

Fonte: a Autora

\subsubsection{Fonte externa - localização do fornecedor}

Examinando as respostas dadas às variáveis de localização do fornecedor, verifica-se que pouco mais da metade (56\%) das empresas realizam grande número de compras de fornecedores internacionais, localizados em outros países. Por sua vez, 28\% dos respondentes, realizam um grande número de compras de fornecedores localizados no país da matriz. 
Tabela 4: Localização - compra de fornecedor nacional ou internacional

\begin{tabular}{|l|c|l|c|}
\hline & $\begin{array}{l}\text { Sua subsidiária realiza um grande } \\
\text { número de compras de } \\
\text { Fornecedores localizados no país } \\
\text { da matriz }\end{array}$ & $\begin{array}{l}\text { Sua subsidiária realiza um } \\
\text { grande número de compras de } \\
\text { Fornecedores de outros países }\end{array}$ & $\begin{array}{l}\text { Localização } \\
\text { Fornecedor }\end{array}$ \\
\hline Baixa & $47 \%$ & $25 \%$ & $36 \%$ \\
\hline Razoável & $25 \%$ & $19 \%$ & $22 \%$ \\
\hline Alta & $28 \%$ & $56 \%$ & $42 \%$ \\
\hline Mediana & 46 & 41 & 43,5 \\
\hline Média & 54,00 & 54,00 & 54,00 \\
\hline Desvio Padrão & 15,75 & 26,55 & 21,15 \\
\hline
\end{tabular}

Fonte: a Autora

\subsubsection{Quadro Resumo das Variáveis do Modelo Global Sourcing}

Um quadro resumo da avaliação das subsidiárias, no que diz respeito aos fatores do modelo de GS, indica que existe uma alta autonomia das subsidiárias, forte integração no relacionamento com matriz; alta realização compras intrafirma e também de fornecedores internacionais. Os pontos estão resumidos no quadro a seguir.

\section{Quadro 12 - Quadro Resumo das Variáveis do Modelo}

\begin{tabular}{|l|l|}
\hline Autonomia & $\begin{array}{l}\text { Alta autonomia da subsidiária em relação à } \\
\text { matriz de uma forma geral }\end{array}$ \\
\hline Integração & $\begin{array}{l}\text { Forte integração no relacionamento com } \\
\text { matriz }\end{array}$ \\
\hline Transferência & Alta utilização de transferência intrafirma \\
\hline Fornecedor & Forte participação de fornecedor \\
& internacional \\
\hline
\end{tabular}

Fonte: a Autora 
A relação matriz e subsidiária foi o aspecto melhor avaliado pelos respondentes, suportado pela forte confiança da matriz na sua subsidiária que também se reflete na forte troca de conhecimento e forte relação de trabalho.

A componente de maior destaque da variável autonomia foi o desenvolvimento de novos fornecedores e parceiros (88\%), o que demonstra o grau de relevância que representa desenvolver novas alternativas de fornecimento pela área de compras da subsidiária.

Num primeiro momento, podemos levar em consideração que a matriz desempenha forte influência na subsidiária, e que pela relação de confiança existente, a subsidiária tem autonomia para tanto realizar projetos como desenvolver novos fornecedores. Porém, a subsidiária não realiza atividades de compra para a matriz ou para outras subsidiárias, o que pode demonstrar que a integração acontece no sentido matriz-subsidiária sem, no entanto sem o fluxo inverso.

\subsection{Análise das Correlações}

Neste capítulo, o objetivo é analisar os dados para testar os pressupostos levantados no decorrer do texto. Serão empregadas duas técnicas de análise multivariadas: a correlação linear simples e a regressão linear múltipla.

A correlação de Pearson permite verificar como as variáveis independentes estão relacionadas entre si e com as variáveis dependentes. O esperado é que exista uma baixa correlação entre as variáveis independentes, evitando o efeito da multicolinearidade, isto é, o fato de uma variável entrar no modelo de regressão não pela sua força para explicar a variável dependente, mas em virtude da sua associação com outra variável independente. 


\subsubsection{Análise da Correlação entre as Variáveis do Modelo de Gestão}

O resultado da correlação de Pearson das variáveis independentes está apresentado na tabela abaixo. De um aspecto geral, as correlações são fortes e apresentam estatisticamente resultado significativo, ao nível de $1 \%$.

Tabela 5 - Correlação das Variáveis do Modelo de Gestão

\begin{tabular}{|c|c|c|c|c|c|c|}
\hline & Autonomia & Integração & Transferência & Fonte externa & Média & Desvio \\
\hline Autonomia & 1 & & & & 3,49 & 0,68 \\
Integração & $0,391 * *$ & 1 & & & 3,4 & 0,62 \\
Transferência & 0,216 & $0,217^{* *}$ & 1 & & 3,09 & 1,23 \\
Fonte externa & $0,379 * *$ & $0,235^{* *}$ & $0,259^{* *}$ & 1 & 3,36 & 1,14 \\
& & & & & & \\
\hline
\end{tabular}

$* * \mathrm{p}<0,01 \quad * \mathrm{p}<0,05$

Fonte: a Autora

Na tabela 5 acima, a autonomia das subsidiárias apresenta-se correlacionada com a iniciativa de fonte externa. Assim, quanto mais autônoma a subsidiária, maior sua possibilidade em realizar iniciativas próprias, como atividades de compra independente da matriz assim como projetos. Isso é reforçado pela não existência de correlação entre autonomia e a transferência intrafirma entre matriz-subsidiária.

Outro resultado que merece destaque é a correlação entre a integração da matriz com a subsidiária para a transferência intrafirma e para a fonte externa. Esse ponto pode ser analisado sob o aspecto de que, quanto maior a integração, maior a comunicação, confiança e colaboração entre os pares de diferentes unidades, maior a possibilidade em gerar maior transferência interfirma. 
Por outro lado, não foi possível determinar pelo modelo empírico, uma vez que o resultado das regressões foi insuficiente para determinar a segmentação da participação dos fornecedores em nacionais e internacionais.

Sob outro aspecto, esse processo de comunicação e confiança pode também ser um ponto facilitador para maior possibilidade de compra de fonte externa. O que pode estar por trás dessa percepção pelos respondentes seja o mesmo aspecto, uma vez que este resultado seja conseqüência da relação de confiança, troca de conhecimento e forte relacionamento de trabalho, pode influenciar na iniciativa de busca de fonte externa de fornecimento também.

Um outro fator que não temos condições de analisar, mas que podemos inferir, refere-se ao fato que as subsidiárias, assim como a matriz, podem apresentar necessidades diferentes de itens de compra e que muitas vezes o processo de comunicação e sinergia contribua para que essas necessidades sejam supridas de formas distintas, pela combinação ora de transferência e ora de fonte externa.

\subsection{Análise de regressão múltipla}

A análise de regressão múltipla é utilizada com objetivo de explicar os valores para uma variável dependente. No estudo, as variáveis dependentes concentram-se na decisão estratégica de compras, podendo ser utilizada transferência, ou seja, a compra intrafirma, através da transferência pela matriz ou outras subsidiárias, ou pela denominada fonte externa, a compra de fornecedor externo à empresa, podendo estar localizado no país ou fora dele. A escolha pela análise de regressão múltipla, a mais amplamente usada e versátil, é aplicável em tomadas de decisões em negócios, onde cada caso relaciona um fator (ou fatores) a um resultado específico.

A análise de regressão múltipla é uma técnica estatística que pode ser usada para analisar a relação entre uma única variável dependente (critério) e diferentes variáveis independentes 
(preditoras). Fornece um meio de avaliar objetivamente a magnitude e a direção (positiva ou negativa) da relação de cada variável independente (COLLINS, 2006). Duas variáveis são ditas correlacionadas se as mudanças em uma variável são associadas com as mudanças na outra.

Tabela 6 - Modelo de regressão para desenvolvimento de decisão estratégica de compras

\begin{tabular}{|l|l|}
\hline Compra da Matriz (transferência) & Compra fora/externa \\
\hline
\end{tabular}

\begin{tabular}{|l|c|c|}
\hline Constante & 1,894 & 0,692 \\
Autonomia & $-0,135$ & $0,564^{* *}$ \\
Integração & $0,496^{* *}$ & 0,187 \\
F & 4,633 & 15,229 \\
$\mathrm{R}^{2}$ & 0,041 & 0,143 \\
\hline
\end{tabular}

$* * \mathrm{p}<0,01$

Fonte: a Autora

Quadro 13 - Resumo dos pressupostos sobre decisão estratégica de compras

\begin{tabular}{|r|r|}
\hline Decisão estratégica de compras - Autonomia & Resultado \\
\hline H1a Quanto maior a autonomia da subsidiária, maior a possibilidade & Não confirmado \\
de compra de fonte interna, isto é, da subsidiária receber & \\
compras realizadas pela matriz e/ou outras subsidiárias e \\
transferidas para a subsidiária (transferência intrafirma).
\end{tabular}




\begin{tabular}{|c|c|}
\hline Decisão estratégica de compras - Integração & Resultado \\
\hline $\begin{array}{l}\text { H2a Quanto maior o grau de integração da subsidiária, maior a } \\
\text { possibilidade da compra de fonte interna, da subsidiária receber } \\
\text { compras realizadas pela da matriz e/ou de outras subsidiárias } \\
\text { (transferência intrafirma). }\end{array}$ & Confirmado \\
\hline $\begin{array}{l}\text { H2b Quanto maior o grau de integração da subsidiária, menor a } \\
\text { possibilidade da realização das compras de fonte externa, de } \\
\text { fornecedores localizados tanto no mercado local como } \\
\text { internacional. }\end{array}$ & Não confirmado \\
\hline
\end{tabular}

Fonte: a Autora 


\section{CONCLUSÃO}

Este capítulo tem como objetivo apresentar algumas conclusões sobre os principais resultados do estudo, bem como as contribuições, suas limitações e propostas para pesquisas futuras.

\subsection{Considerações Finais}

Em alinhamento com os estudos mais recentes da área, o presente trabalho buscou compreender os aspectos e variáveis que impactam na forma como as subsidiárias brasileiras de multinacionais atuam na decisão estratégica de compras relacionadas no Global Sourcing.

Certamente há muitas facetas relacionadas à teoria de Global Sourcing e são muitas as relações existentes no seu fluxo, tanto internas quanto externas. O foco escolhido foi em analisar os aspectos de relacionamento de gestão entre matriz e subsidiária e, optou-se por concentrar em dois aspectos, autonomia e integração.

O direcionamento da escolha desses aspectos teve como base a pesquisa na literatura que até onde temos conhecimento, tem concluído que as empresas que operam globalmente têm redefinido sua produção e estratégia de marketing, porém elas mais ou menos falharam em fazê-lo no que diz respeito à estratégia e atividade de Sourcing (KOTABE; MURRAY, 2004; TRENT; MONCZKA, 2002).

Conforme apresentado no início deste trabalho, a atividade de compras tem papel relevante no valor nas corporações. Em geral, a representatividade do valor que é gerado pelo processo de compras responde por mais da metade do valor do faturamento da empresa, como é o caso da indústria automotiva, química, de bebidas e alimentos, para citar algumas (CAPS RESEARCH, 2009). Essa magnitude é pano de fundo para que estudos relacionados à Global Sourcing estejam em destaque dentro da cadeia de valor das empresas. 
Vários estudos relacionados à gestão estratégica de empresas internacionalizadas, e especialmente os relacionados à gestão das subsidiárias, por autores brasileiros, como Oliveira, JR. (et al. 2009), FLEURY, FLEURY; (2007), Borini (2009), entre outros, têm se dedicado ao assunto dando relevância para o tema no cenário acadêmico.

O modelo proposto abordou a importância das diretrizes estratégicas na relação da matriz com as subsidiárias (autonomia e integração) e a decisão estratégica de compras sob os aspectos de propriedade (intrafirma e externa) e de localização do fornecedor (nacional ou internacional).

O resultado obtido comprova alguns dos pressupostos elaborados para o modelo de abordagem. A figura 15 apresenta a adequação do modelo proposto para os resultados encontrados.

Figura 15 - modelo de abordagem de Global Sourcing nas subsidiárias brasileiras de multinacionais.

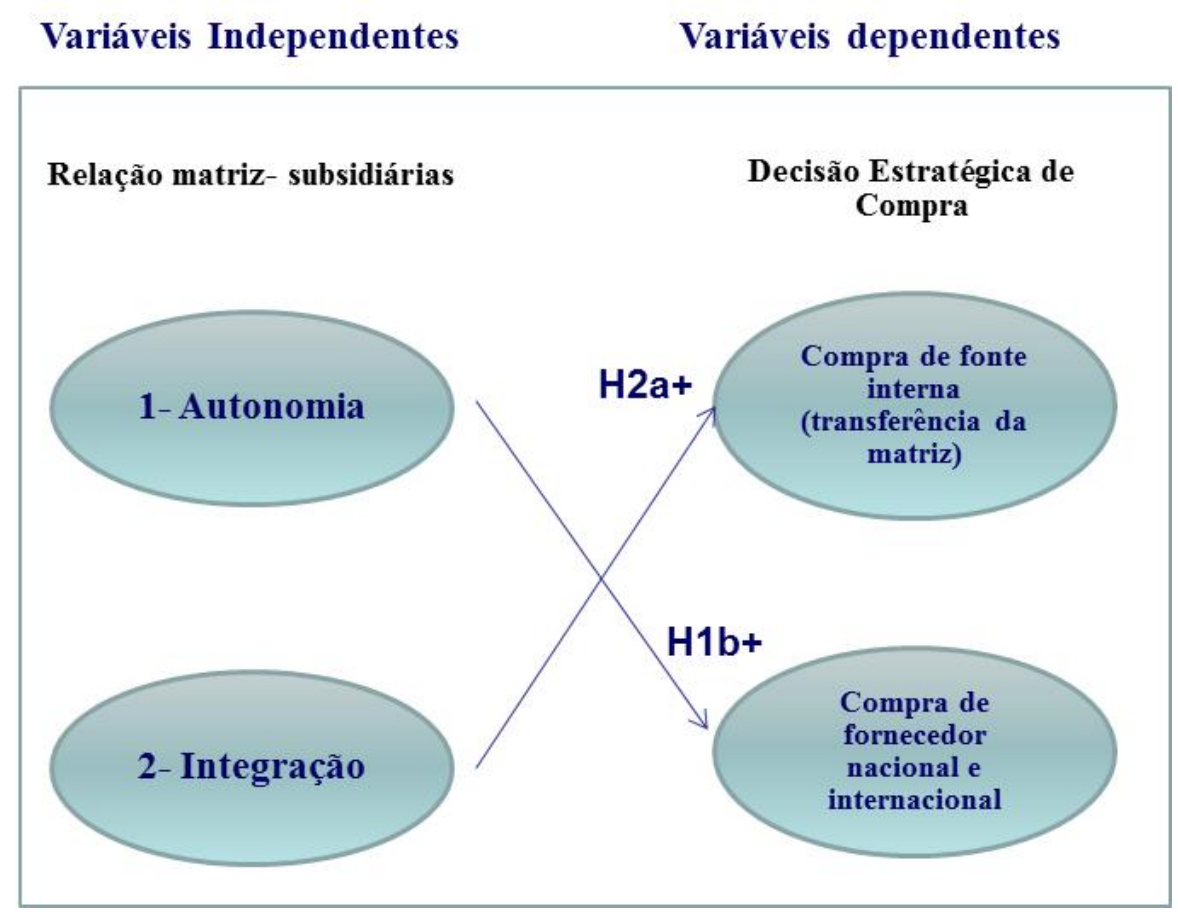

Fonte: a Autora 
Importante apresentar o perfil das empresas pesquisadas, competitivas globalmente na área de atuação; consideram extremamente importante a relação com os fornecedores e parceiros brasileiros e mundiais, e tem como região de comando o Brasil e os países da América Latina, seguida de América do Norte, Europa, Ásia e por última região da África.

O estudo conclui que as subsidiárias gozam de autonomia para desenvolver fornecedores tanto no mercado local quanto internacional. Atendendo a uma demanda de mercado dinâmica, a pesquisa mostra que as empresas estão buscando a eficiência global com responsividade local. Realizam grande número de compras de fornecedores internacionais, ao mesmo tempo em que, também recebem transferência das compras realizadas pela matriz.

Assim, o destaque principal do estudo confirma que as subsidiárias aqui localizadas, têm como ponto chave a transferência de competências para as subsidiárias, e através de um processo de aprendizagem e autonomia, desempenham elas próprias às atividades também dominadas pela matriz no Global Sourcing.

A análise do resultado do modelo, de uma forma geral, apresenta evidências de que a estrutura de modelo organizacional está mais delineada para o de coordenação (ARNOLD, 1999), que apresenta como características o uso da economia de escala, onde economias de escala referem-se à obtenção de menores custos unitários pelo aumento poder de mercado através de volume e padronização de categorias.

Ao invés de uma forte hierarquia, busca-se a cooperação entre as unidades de negócios. Diferente de um controle rígido sobre as atividades da subsidiária, a integração permite um alinhamento estratégico entre as necessidades da subsidiária e as diretrizes da matriz.

Para isso, as subsidiárias entendem a importância e praticam através de intensa comunicação, troca de conhecimento, resultando na resposta mais alta da pesquisa, a de forte confiança da matriz na subsidiária.

Como as subsidiárias não podem mais competir como uma coleção de subsidiárias nacionalmente independentes, pelo aumento da competição baseada na habilidade da firma 
para integrar as atividades das subsidiárias através da localização geográfica (BARTLETT; GHOSHAL, 1989; KOTABE; MURRAY, 2004; NOHRIA; GHOSHAL, 1997; PORTER, 1986). Nesse contexto, para atingir eficiência global, a reponsividade local e aprendizado global são competências vitais para a competitividade segundo Barlett et al. (2004).

\section{Autonomia para compra de fornecedor nacional ou internacional}

A hipótese validada pelo modelo de forma empírica, estabelece que quanto maior o grau de autonomia da subsidiária, maior a compra oriunda de fonte externa, ou seja, de fornecedores localizados tanto no mercado local como internacional.

O perfil das empresas da amostra indica que 89\% das subsidiárias são consideradas estrategicamente importantes para a matriz, e reflete o reconhecimento que essas empresas possuem e conseqüentemente, embasam o alto grau de autonomia e independência nos processos de decisão. Isso reflete tanto nos aspectos com índices superiores a 80\%, para o (i) desenvolvimento de novos fornecedores e parceiros e (ii) responsabilidade em executar importantes projetos corporativos.

Em contrapartida, o fluxo de desenvolvimento e conhecimento gerado nas subsidiárias, pela maior autonomia, não é replicado para a matriz e outras unidades. Como podemos observar nas questões referentes à (i) realização de compra para matriz e outras subsidiárias, e (ii) desenvolvimento de produtos/processos organizacionais em parceria com fornecedores e que hoje são adotados em outras subsidiárias, ambas com retorno na baixa graduação.

\section{Integração para transferência}

A transferência de compras interfirma foi validado pelas variáveis do aspecto de integração. A transferência é explicada pelo forte relacionamento existente através de constantes visitas de executivos e troca de conhecimento. São fundamentais para o processo de integração, a comunicação e socialização (NOHRIA; GHOSHAL, 1997). Podemos supor que as empresas da amostra não são empresas iniciantes no ciclo de vida, já que a integração é considerada a última fase do processo de globalização movimento envolve uma única organização global integrada (Malnight, 1992). Como as subsidiárias já teriam aumentado sua experiência e competências, com trocas entre as unidades expandidas, a oportunidade emerge para integrar 
unidades de operação espalhadas pelo mundo fortalecendo não somente as operações internacionais, mas também as domésticas.

\subsection{Contribuições do Estudo}

A validação de algumas das hipóteses, do ponto de vista da decisão estratégica de compras, contribui para os estudos sobre Global Sourcing, respaldada pelo arcabouço teórico do tema. Os resultados mostraram que a autonomia e integração na relação matriz-subsidiárias são fatores essenciais na decisão estratégica de compras das empresas.

A pesquisa envolvendo 181 empresas trouxe um panorama geral sobre esse tema com amplitude e profundidade através da originalidade da iniciativa. O referencial teórico vinculando aspectos importantes do processo de aquisição de bens e itens, relacionado com a gestão das empresas remonta a complexa relação entre diferentes unidades.

O estudo também trouxe o entendimento que para atuar globalmente na área de compras, através do GS, o ponto relevante para empresas é elas adaptarem as suas estruturas organizacionais e governança numa organização cada vez mais complexa. Da mesma forma, novas competências são demandadas para que a fluidez dos processos contribua para o sucesso das empresas.

Também comprovamos que aspectos menos ligados à estruturação e mais voltados a relacionamento, são os diferenciais que vem contribuindo para o modelo transnacional, de rede diferenciada.

\subsection{Limitações do Estudo e Sugestões para Futuras Pesquisas}

Este último capítulo identifica as limitações do estudo e propõe sugestões para futuras 
pesquisas. As limitações do estudo referem-se tanto a escolha das variáveis para a composição do modelo de abordagem do Global Sourcing quanto ao método de investigação utilizado.

As variáveis do modelo foram restritas a apenas duas e ampliar o tema, traria uma abordagem mais completa, pela inclusão das variáveis de diretrizes estratégicas da matriz como orientação empreendedora, gestão da subsidiária sob o aspecto de iniciativa própria e a gestão da relação da subsidiária com o ambiente externo, pela inclusão do contexto competitivo e rede externa.

No campo específico da orientação empreendedora, traria para análise da empresa novas oportunidades de negócios e estaria relacionada a questões de credibilidade e liberdade para a tomada de decisões de risco (BIRKINSHAW, 1997). Com relação às iniciativas, poderiam ser investigadas as globais, externas (mercado) e internas das subsidiárias (BIRKINSHAW, 1997).

Outra variável sugerida, de contexto competitivo, tem como proposta a análise do conceito do que Porter (1990) denomina “diamante da vantagem nacional” e seus atributos: condições dos fatores da posição do país, condições da demanda, estrutura e rivalidade das empresas e setores correlatos e de apoio no país. O conceito aborda os benefícios auferidos pelas empresas de base doméstica quando as empresas têm fornecedores que são competidores globais, e que podem trazer as inovações do exterior para serem implementadas nas empresas do país. Da mesma forma, o fator de competitividade dos fornecedores internos, que reflete em vantagens oferecidas às empresas.

Uma limitação do estudo refere-se à falta de variáveis de controle, como por exemplo, relacionadas à maturidade, ciclo de vida das empresas e também uma maior profundidade nas análises estatísticas, que poderiam trazer análise mais completas.

Outro aspecto é o método survey que foi adequado dentro do objetivo do estudo, mas que dentro das limitações da pesquisa não é possível aprofundar alguns aspectos, em especial, quanto as questões e por vezes, pode tornar-se muito generalizado.

Assim, podemos identificar para estudos futuros, a análise do aspecto de localização dos 
fornecedores. Um estudo direcionado para fornecedores oriundos de regiões emergentes, tais como os países do oriente, considerados de baixo custo operacional e que vem ganhando destaque no competitivo contexto das empresas multinacionais.

Adicionalmente, outra sugestão seria o aprofundamento das próprias questões envolvidas neste trabalho, com estudos de casos, onde possa ser exploradas outros pontos, tais como as redes de negócios, estrutura organizacionais, entre outros. Certamente trariam contribuições aos estudos relacionados a gestão estratégica de empresas internacionalizadas e especialmente os relacionados a gestão das subsidiárias, tema explorado por autores brasileiros, com destaque para Oliveira, JR. et al (2009), Fleury, Fleury (2007), Borini (2009) que têm se dedicado ao assunto e dado relevância para o tema no cenário acadêmico. 


\section{REFERÊNCIAS}

ANSOFF, H. Igor. Administração estratégica. São Paulo: Atlas, 1990. 214p.

ARNOLD, U.; Global Sourcing - An Indispensable Element in Worldwide Competition, Management International Review, Fourth Quarter, 1989.

ARNOLD,U.; Organizational of global sourcing: ways towards an optimal degree of centralization, European Journal of Purchasing \&Supply Management 5, pg 167-174; 1999.

ARNOLD,U.; Purchasing consortia as a strategic weapon for highly decentralized multidivisional companies. Conference Proceedings 6th IPSERA Conference, University of Naples Federico II, Italy, pp 1-16; 1997.

BARLETT,C.A.; GHOSHAL, S. Managing across borders: the transnational solution. Boston: Harvard Business School Press, 1989 .

.Gerenciando empresas no exterior: a solução transnacional. São Paulo. Makron Books, 1992. . 2nd ed. Cambridge, Mass.: Harvard Business School Press, 1998.

BARLETT,C.A.; GHOSHAL, S.; BIRKINSHAW,J. Transnational management: Text, cases and readings in cross border management. Burr Ridge, IL: Irwin/McGraw-Hill; 2003.

BATISTA JR, P.N., Mitos da Globalização, USP, Estudos Avançados, São Paulo, 1998.

BIRKINSHAW,J; Strategy and management in MNE subsidiaries. In: Rugman, a.; Brewer, T. (Ed.) Oxford handbook of international business. Oxford: oxford University Press, 2001.

BIRKINSHAW,J.; MORRISON A. Configuration of strategy and structure in subsidiaries of multinational corporations. Journal of International Business Studies, p. 729-753, 1995. 
BIRKINSHAW,J.; HOOD,N. Multinational subsidiary evolution: capability and charter change in foreign-owed subsidiaries companies. Academy of Management, v. 23, n.4, p. 77395, 1998.

BIRKINSHAW,J.; HOOD,N.; JONSSON, S. Building Firm-Specific Advantages in Multinacional Corporations: The role of subsidiary initiative. Strategic Management Journal, vol. 19, n.3, p. 221-241, 1998.

BIRKINSHAW,J.; Strategy and Management in MNE subsidiaries. In. A. Rugman \& T. Brewer (eds), Oxford handbook of international business. Oxford University Press, 2001.

BORINI,F.M; URBAN,T; FLEURY, MT,ROSAS,A. Tradicionais x ultimas entrantes: estudo de caso da indústria de cimentos. In Fleury, MT; Fleury,A. Internacionalização dos países emergentes. São Paulo. Atlas, 2007.

BORINI,F.M.; Transferência, Desenvolvimento e reconhecimento de competências organizacionais em subsidiárias estrangeiras de empresas multinacionais brasileiras. Tese de Doutorado em Administração de Empresas, Universidade de São Paulo, São Paulo, 2008.

BOVET, D; MARTHA,J. Value nets: Breaking the Supply Chain to Unlock hidden profits, John Wiley \& Sons, New York, NY, 2000.

Business International, The effects of US Corporate Foreign Investment 1970-1980, New York: Business International Corporation, 1982.

BUTTER;F,A.G.; LINSE;K.A.; Sloan Management Review; Rethinking Procurement in the Era of Globalization, MIT Massachusetts Institute of Technology, Fall 2008.

CANNICE, M.V.; CHEN, R; Global Integration and the performance of multinationals subsidiaries in emerging markets. Ivey Business Journal, Jan. 2006.

CAPS Research Center of Advanced Purchasing Studies - Global Research Center for 
Strategic Supply Management. School of Business at Arizon State University - Cross industry report standard benchmarks; novembro/2009. Disponível em http://www.capsresearch.org. Acesso em 07/04/2010.

CARR, A.S., PEARSON, J.N. The impact of purchasing and supplier involvement on strategic purchasing and its impact on firm's performance. International Journal of Operations and Production Management, vol. 22, n. 9, pp. 1032-1053, 2002.

CARTER, J.R.; NARASIMHAN,R.; Purchasing in the international marketplace: Implications for operations. Journal of Purchasing and materials management; 1990.

CAVUSGIL, S.T.; YAPRAK, A.; YEOH; P.L.; A decision-making framework for Global Sourcing; International Business Review, 2 (2), 143-156; 1993.

CHANDLER, A.D.JR; Strategy and Structure: Chapters in the History of the American Industrial Enterprise; Cambridge, MA: MIT PRESS; 1962.

CHEUNG, M.S. Inter firm knowledge sharing and its effect on relationship value: a global supply chain perspective. A dissertation presented for the doctor of philosophy degree. The University of Tennessee, Knoxville. August, 2005.

COLLIS,J;HUSSEY,R. Pesquisa em administração. Porto Alegre: Bookman, 2006.

CZINKOTA, M.R.; RONKAINEN, I.A.. A forecast of globalization. International business and trade: Report form a Delphi study. Journal of World Business, 40 (2), 111-123; 2005.

COOPER.D;SCHINDLER,P. Métodos de pesquisa em administração. Porto Alegre: Bookman, 2006.

CYERT, R.; MARCH, J. A. A behavioral theory of the firm. New York: Prentice Hall, 1963.

DANTAS, E. B. - Marketing descomplicado. Brasília: Senac, 2005. 
DAVIDSON , W.H.; 1982, Global Strategic Management. New York: John Wiley \& Sons.

D'CRUZ, J. Strategic management of subsidiaries. In: ETERMAD, H.; SEGUIN DULUDE,

L. (Ed.) Managing the multinational subsidiary. London: Croon Helm, 1986.

DELOITTE; Innovation in emerging markets: Strategies for achieving commercial success 2008. Disponível em www.deloitte.com/manufacturing. Acesso em 15/11/2009.

DUNNING, J.H. The eclectic paradigm of international production: a restatement and some possible extensions. Journal of International Business Studies, Abington, v. 8, n.1, p 131, spring 1988.

DUNNING, J.H. The globalization of business, the challenge of the 1990s, Routledge, London and New York, 1993.

The eclectic paradigm as an envolve for economic and business theories of MNE's activities. International Business Review, 2000.

- 'The eclectic paradigm of international production: a restatement and some possible extensions', Journal of International Business Studies, v.11, n.1, pp9-31, 1988.

. Multinational enterprises and the global economy. Workingan: Addison-Wesley, 1993.

FAES, W.; MATTHYSSENS, P.; VANDENBEMPT, K.; The pursuit of global purchasing synergy. Industrial Marketing Management 29 (67), 539-553; 2000.

FAYERWEATHER, J. International business management: conceptual framework. NeW York: McGraw Hill, 1969.

FERNANDES, B.H.R.; JUNIOR, R.E.S.; Tipologia de novos empreendimentos internacionais. In: Internacionalização e os países emergentes, São Paulo, 2007. 
FLEURY, A. The changing pattern of operations management in developing countries. International Journal of Operations and Production Management, v. 19, p. 5-6, 1999.

.(org.), Internacionalização e os países emergentes, São Paulo, Altas, 2007.

Global Value Chains and Development Policies: a critical assessment based on

Brazilian experiences - Discussion paper prepared for the session "Policies for Global Production Networks and Local Decent Work”, IILS Conference on “Decent Work, Social Policy and Development”, ILO Headquarters, Geneve, 30 November - 01 December 2006.

GEREFFI, G.; STURGEON, T.; BIESEBROECK, J.V.; Value chains, networks and clusters: reframing the global automotive industry; Journal of Economic Geography pp. 297-321; 2008.

GRIFFITH, D.A.; MYERS, M.B. The performance implications of strategic fit of relational norm governance strategies in global supply chain relationships. Journal of International Business Studies; (36) 254-269; 2005.

Global Value Chain: Disponível em http://www.globalvaluechains.org. Acesso em 20/09/2009.

GUPTA, A.K.; GOVINDARAJAN, V. Knowledge flows and the structure of control within multinational corporations. Academy of Mangement Review, v. 16, n.4, p. 768-92, 1991.

HANDFIELD,R.B._US global sourcing: Patterns of development; International Journal of Operations \& Production Management; Bradford; Vol. 14, Iss. 6; pg. 40, 12 pgs.; 1994.

HANDFIELD,R.B.; NICHOLS, E.L. JR. Key issues in global supply base management. Industrial Marketing Management 33; 29-35; 2004.

HEINFIELD,R.B; US Global sourcing: patterns of development; 1994. 
HEFLER, D.F., Global Sourcing: offshore investment strategy for the 1980s. Journal of Businesss Strategy ; 1986.

HITT, M.A.;IRELAND,R.D.;HOSKISSON, R.E. Strategic Management: competitiveness and globalization. New York: South-Western College Publishing, 1999.

HITT, M.A.; IRELAND, R.D.; HOSKISSON, R.E. Administração estratégica: competitividade e globalização. São Paulo, Pioneira Thomson Learning, 2003.

The dilemma of centers of excellence - contextual creation of knowledge versus global transfer knowledge. Série de Working Papers. Disponível em <http://web.chs.dk/departments/int/publications/wp_2000/wp8-2000_tp.pdf.> ; 2000.

HUBERT, S.H.; Value Chain Analysis for Policy-Makers and Practitioners; Geneva, International Labour Organization; 2005.

INSCH, G. S.; STEENSMA, H.K., The Relationship between Firm Strategic Profile and Alliance Partner's Characteristics - Journal of Managerial Issues, vol.XVII, number 3, Fall, 21:339; 2006.

JARILLO, JC.C; MARTINEZ, J.L. Different roles for subsidiaries: the case of multinational corporation in Spain. Strategic Management Journal, v.11, n.7, p. 501512,1990.

JOHANSON, J; VAHLEN, J.E. The internationalization process of the firm: a model of knowledge development and increasing foreign market commitment. Journal of International Business Studies, 8, p.23-32, 1977.

KOGUT, B. Country capabilities and the permeability of borders. Strategic Management Journal. Vol. 12, p. 145-164, 1991.

KOTABE, M; OMURA,G.S. Sourcing strategies of European and Japanese multinationals: a comparison. Journal of International Business Studies, 1989. 
KOTABE, M.; Corporate product policy and innovative behavior of European and Japanese multinationals: An empirical investigation', Journal of Marketing, April, pp. 1933; 1990.

KOTABE, M.; Global Sourcing Strategy: R\&D, Manufacturing, and Marketing Interfaces; Quorum Books, 1992.

KOTABE, M.; MURRAY, J.; JAVALGI, R.G. Global sourcing of services and market performance: an empirical investigation, Journal of international marketing, 6,4, ABI/INFOMA Global, pg. 10; 1998.

KOTABE, M; MURRAY, J Linking product and process innovations and modes of international sourcing in global competition: a case of foreign multinational firms. Journal of International Business, 1989.

KOTABE, M.; MURRAY, J.Y. Global sourcing strategy and sustainable competitive advantage. Industrial Marketing Management, 33(1), 7-14, 2004.

KOTABE, M.; MURRAY, J.; ZHOU, J.N. Strategic alliance-based source and marketing performance: evidence from foreign firms operating in China; Journal of International Business Studies, 36, 187-208, Palgrave Macmillan Ltd., 2005.

KOTABE, M.; MOL,M.J.; KETKAR.S; An evolutionary stage model of outsourcing and competence destruction: a triad comparison of the consumer electronics industry; Management International Review; 2008.

LEE S.S.; Global Sourcing Strategy and its impact on Business performance: an empirical study of the fit between global sourcing and strategic decisions; Dissertation of the degree of Doctor in Management; Faculty of Graduated College in the University of Nebraska; 1996.

LEENDERS, MR.R.; FEARON,H.E.; ENGLAND,W.B. Purchasing and materials management, Irwin, Boston, MA., 1989. 
LIU, H.; MCGOLDRICK,P; 1995; International Sourcing: patterns and trends, in International retailing: Trends and strategies. London: Pitman Publising, 99-116.

LUO, Y. Market-seeking MNEs in an emerging market: how parent-subsidiary links shape overseas success. JIBS; 34, 290-309; 2003.

MALNIGHT, T.W.. Globalization of na ethnocentric firm: an evolutionary perspective. Strategic Management Journal (1986-1988); Feb-1995; 16;2; pg. 119.

MARCONI, M.A.; LAKATOS, E.M.; Fundamentos de Metodologia Científica; $6{ }^{\text {a }}$ Ed.; São Paulo; Atlas; 2005.

MARTINS, G.A.; THEOFILO, C.R. Metodologia da investigação Cientifica para Ciências Sociais Aplicadas, Atlas, 2007.

MATHEWS,J.A; Dragon multinationals: new players on 21st century globalization, Asia Pacific Journal of management, vol. 23, n.1, 2006.

MATTHYSSENS, P.; QUINTENS, L; PAUWELS, P. Global purchasing strategy: conceptualization and measurement; Industrial Marketing Management 35 (2006) 881-891

MAZZALI,L.; COSTA,V.M.M. As formas de organização em rede: configuração e instrumento de análise da dinâmica industrial. Revista de Economia Política, v. 17, n. 4, p. 121-39, out/dez.1997.

MCCLINTOCK, K.A.; Global sourcing for contract manufacturing case study - Banner Pharmacaps Inc. Production and Inventory Management Journal;; 43; 1/2; ABI/INFORM Global pg 63; First Quarter 2002.

MINBAEVA,D; PEDERSEN, T,BJORKMAN,I;FEY,C.PARK,H.J. MNC Knowledge transfer, subsidiary absorptive capacity and HRM. Journal of International Business Studies, 2003. 
MONCZKA R.M.; TRENT, R.; HANDFIELD, R. Purchasing and Supply Chain Management ( $2^{\text {nd }}$ ed.) Cincinnati, OH: Southewestern Publishing, College Division; 2001.

MONCZKA R.M.; TRENT, R.J. International purchasing and global sourcing - what are the differences?; Journal of Supply Chain Management; 29;4; ABI/INFORM Global pg 26; Fall 2003a.

.Understand integrated Global Sourcing, International Journal of Physical Distribuition 607 and Logistics Management; 33; 7, ABI/INFORM Global pg. 607; 2003b. Achieving Excellence in Global Sourcing, MIT Sloan Management Review, Fall 2005, vol. 47, no.1.

. Effective Global sourcing and supply for superior results; Institute of Supply Management and the W.P. Carey School of Business at Arizona State University; 2006.

MOXON,R.W. The motivation for investment in offshore plants: the case of the US electronics industry. Journal of Business Studies, 1975.

MULLER, W. AG, Annual Report 1995; 1996.

MURRAY, J.Y. Strategic alliance based global sourcing strategy for competitive advantage: a conceptual framework and research propositions. Journal of International Marketing; 2001.

MURRAY, J.Y.; KOTABE, M.; WILDT, AR. Strategic and financial performance implications of global sourcing strategy: a contingency analysis; Journal of International Business Studies, 1994.

. Global sourcing strategies of US subsidiaries of foreign multinationals, 
Management International Review; 35; 4; ABI/INFORM Global pg. 307; 1995.

. Strategic alliance-based sourcing and market performance: evidence from foreign firms operating in China, Journal of International Business Studies, 2005.

MURRAY, J.Y; KOTABE, M.; Sourcing Strategies of US service companies: a modified transaction-cost analysis, Strategic Management Journal vol.20, num.9, 791-809, Sep1999.

NOBEL, R. BIRKINSHAW, J, Innovation in multinacional corporations: control and communication patterns in international $R \& D$ operations. Strategic Management Journal 19 (5), 479-496; 1998.

NOHRIA, H.; GHOSHAL,S. The differentiated network: organizing multinational corporations for value creation. San Francisco: Jossey-Bass Publisher, 1997.

NONAKA, I.; TAKEUCHI, H. The knowledge creating company. New York, Oxford Universtigy Press, 1995.

OLIVEIRA JUNIOR;.M.M.; Transferência de conhecimento e Best practices em redes corporativas globais. In: XXV ENANPAD. Anais. Campinhas: Enanpad, 2001.

OLIVEIRA JUNIOR;.M.M; BOEHE, D.M.; BORINI, F.M. Estratégia e Inovação em corporações multinacionais - a transformação das subsidiárias brasileiras; São Paulo; Saraiva; 2009.

OVIATT, B.M.; MCDOUGALL, P.P, SIMON, M. and SHRADER, R.C. 'A New Venture Without Geographic Limits: Case History of a Global Start-up', in N.C. Churchill, W.D. Bygrave, J.A. Hornaday, D.F. Muzyka, K.H. Vesper and W.E. Wetzel, Jr (eds.) Frontiers of Entrepreneurship Research, Babson College: Wellesley, MA, pp: 64-78.; 1991.

OVIATT, B.M.; MCDOUGALL, P.P. Toward a theory of international new ventures; Journal of International Business Studies, 36, 29-41; Decade Award Winning Article, 2005. 
PENROSE, E. A teoria do crescimento da firma. Campinas, SP: Editora Unicamp, 2006.

PORSCHE AG. Annual Report 1994/95; 1995.

PORTER, M.E.,Estratégia competitiva. Rio de Janeiro: Campus, 1985.

(Org.) Competition in global industries. Boston: Harvard Business School Press, 1986.

. The competitive advantage of nations. New York: Free Press, 1990.

, Vantagem competitiva: Criando e sustentando um desempenho superior, Rio de Janeiro, Campus, 1992.

PRAHALAD,CK; DOZ, Y. The multinational mission. New York: Free Press, 1987.

PRUSSAK, L. e DAVENPORT, T. Conhecimento Empresarial - Como as Organizações Gerenciam seu Capital Intelectual, Rio de Janeiro, Campus, 1998.

RAJAGOPAL, S.; BERNARD, K.N. Strategic procurement and competitive advantage. International Journal of Purchasing and Materials Mangement, Vol. 29, n.4, pp 13-20; 1993.

RAMAMURTI, R. Developing countries and MNEs: Extending and enriching the research agenda, Journal of International Business Studies, Washington, vol. 35, págs. 277-283, 2004

REZENDE, S. Gradualismo e descontinuidade em processos de internacionalização. Revista de Administração. São Paulo, vol 37, n.1, p.39-50, 2002.

S. Internationalization process: an analytical framework. Revista de administração contemporânea. v.7, n.3, p. 137-156, 2003.

S. Interdependence and the internationalization process of MNCs: uniformity, 
direction and rhythm, ENANPAD, Salvador, 2004.

ROBINSON, R.D.; Direct foreign investment: Costs and benefits. New York: Praeger; 1987.

ROTH, K.; MORRISON, A. Implementing global strategy: characteristics of global subsidiary mandates. Journal of International Business Studies, v.23, n.4, p. 715-36, 1992.

ROZEMEIER, F. How to manage corporate purchasing synergy in a decentralized company? Towards design rules for managing and organizing purchasing synergy in decentralized companies. European Journal of Purchasing and Supply Management, 6 (1), 5$12,2000$.

SCHMITZ, H. Value chain analysis for policy makers and practitioners. Institute of Development Studies. University of Sussex, England, 2005.

SONY Corporation. Procurement Guidelines. Sony, Tokyo; 1994.

SONY Corporation. Annual Report. Sony, Tokyo; 1995.

SRIVASTAVA, R.K., SHERVANI, T.A.; FAHEY, L. (1999). Marketing, business processes, and shareholder value: na organizationally embedded view of marketing activities and the discipline of marketing. Journal of Marketing 63 (Special issue): 168-179.

TALLMAN, S.B.,; YIP,G.S., Strategy and the multinational enterprise. In A. Rugman \& T.Brewer (Eds), The Oxford handbook of international business: 402-427. Oxford: Oxford University Press.; 2001.

TRAUTMANN, G.H.; BALS, L.; HARTMANN, E.. Global sourcing in integrated network structures: the case of hybrid purchasing organizations. Journal of International Management 152009 194-208; 2009. 
TRENT R.J., The use of organizational design features in purchasing and supply management. Journal of Supply Chain Management 40 (3), 4-18; 2004.

TRENT R.J., MONCZKA, R.M. International purchasing and global sourcing - what are the differences. Journal of Supply Chain Management 39 (5), 1-16; 2003.

TRENT R.J., MONCZKA, R.M. Pursuing competitive advantage through integrated global sourcing. Academy of Management Executive, 16 (2), 66-80; 2002.

UTTERBACK, J.M; Innovation and industrial evolution in manufacturing industries. In B.R. Guille \&H. Brooks, ed., Technology and global industry, 16-48, Washington, D.C.; National Academy Press., 1987.

VERNON, R. The location of economic activity in economic analysis and the multinacional enterprise. In J.H. Dunning, ed., Economic analysis and the multinational enterprise, 89-114, London: George Allen \& Unwin., 1974.

WERNER,S.; BROUTHERS,L.E. How international is management. Journal of International Business Studies, 2002.

World Investment Report 2009- United Nations Conference on trade and development.Disponível em . Acesso em 20/09/2009.

YIP, G. Total Global Strategy. New Jersey, Prentice Hall, 1992.

ZAHEER, S.; MOSAKOWSKI, E. The dynamics of the liability of foreignness: A Global Study of Survival in Financial Services, Strategic Management Journal, 18, 439-464; 1997. 
ANEXOS 


\section{Anexo I}

\section{Carta para empresas}

\section{Multinacionais Estrangeiras no Brasil}

O objetivo desta pesquisa é compreender as mudanças nos papéis e responsabilidades das subsidiárias de empresas multinacionais no Brasil.

Esta pesquisa está sendo coordenada no Brasil pelo programa de Mestrado e Doutorado em Administração da FEA/USP e pelo programa de Mestrado em Gestão Internacional da ESPM/SP.

Este questionário esta sendo enviado para uma ampla amostra de subsidiárias de empresas multinacionais no Brasil.

Os participantes receberão um relatório personalizado da situação de sua subsidiária e serão convidados para um workshop exclusivo para as empresas que responderam a pesquisa em que será entregue um relatório geral da pesquisa.

Todos os dados serão tratados de maneira estritamente confidencial. Para tanto os resultados da pesquisa serão apresentados somente de forma agregada.

Nós ficaríamos muito agradecidos se você pudesse dedicar alguns minutos para responder este questionário sobre as operações de sua subsidiária.

Antecipadamente obrigado por sua atenção.

Coordenadores da pesquisa:

Prof. Dr. Moacir de Miranda Oliveira Junior

Mestrado e Doutorado em Administração da FEA/USP

Prof. Dr. Felipe Mendes Borini

Mestrado em Gestão Internacional da ESPM/SP 


\section{Anexo II - Questionário}

\section{Variáveis Independentes}

\section{AUTONOMIA}

Em relação a atuação de sua subsidiária

Discordo Concordo

Totalmente Totalmente

Nos últimos anos, a sua subsidiária ganhou a responsabilidade de executar importantes

projetos corporativos

Essa questão diz a respeito dos processos de inovação de sua subsidiária Nos últimos anos sua subsidiária

Discordo Concordo

Totalmente Totalmente

desenvolveu produtos/processos organizacionais

em parceria com FORNECEDORES e que hoje são

adotados em outras subsidiárias

Sua subsidiária tem total autonomia para

Discordo Concordo

Totalmente Totalmente

\begin{tabular}{|l|l|l|l|l|l|}
\hline desenvolver novos fornecedores e parceiros & 1 & 2 & 3 & 4 & 5 \\
\hline realizar compras para a matriz e outras subsidiárias & 1 & 2 & 3 & 4 & 5 \\
\hline
\end{tabular}

\section{INTEGRAÇÃO}

A matriz corporativa exerce forte influência nas atividades de

Discordo Concordo

Totalmente Totalmente

\begin{tabular}{|l|l|l|l|l|l|}
\hline Compras & 1 & 2 & 3 & 4 & 5 \\
\hline
\end{tabular}

Sua subsidiária já desenvolveu e transferiu várias práticas de para a matriz e/ou outras subsidiárias 


\begin{tabular}{|l|l|l|l|l|l|}
\multicolumn{1}{c}{} & \multicolumn{1}{c}{$\begin{array}{c}\text { Discordo } \\
\text { Totalmente }\end{array}$} & $\begin{array}{c}\text { Concordo } \\
\text { Totalmente }\end{array}$ \\
\hline Compras & 1 & 2 & 3 & 4 & 5 \\
\hline
\end{tabular}

No relacionamento da matriz com a sua subsidiária existe

Discordo Concordo Totalmente Totalmente

1. forte relação de trabalho

2. forte troca de conhecimento

\begin{tabular}{|l|l|l|l|l|}
\hline 1 & 2 & 3 & 4 & 5 \\
\hline 1 & 2 & 3 & 4 & 5 \\
\hline 1 & 2 & 3 & 4 & 5 \\
\hline 1 & 2 & 3 & 4 & 5 \\
\hline
\end{tabular}

3. constante viagem de executivos para matriz

4. forte confiança da matriz na sua subsidiária

\section{VARIÁVEIS DEPENDENTES}

Sua subsidiária realiza um grande número de compras

Discordo Concordo Totalmente Totalmente

da matriz ou de outras subsidiárias de Fornecedores localizados no país da matriz de Fornecedores de outros países

\begin{tabular}{|l|l|l|l|l|}
1 & 2 & 3 & 4 & 5 \\
\hline 1 & 2 & 3 & 4 & 5
\end{tabular}


Anexo III 